San Jose State University

SJSU ScholarWorks

Master's Theses

Master's Theses and Graduate Research

Fall 2016

\title{
Exposure Assessment of Asthma and Modeling of PM2.5 during the 2007 Southern California Wildfires
}

Areana Flores

San Jose State University

Follow this and additional works at: https://scholarworks.sjsu.edu/etd_theses

\section{Recommended Citation}

Flores, Areana, "Exposure Assessment of Asthma and Modeling of PM2.5 during the 2007 Southern California Wildfires" (2016). Master's Theses. 4752.

DOI: https://doi.org/10.31979/etd.w3fg-43ma

https://scholarworks.sjsu.edu/etd_theses/4752

This Thesis is brought to you for free and open access by the Master's Theses and Graduate Research at SJSU ScholarWorks. It has been accepted for inclusion in Master's Theses by an authorized administrator of SJSU ScholarWorks. For more information, please contact scholarworks@sjsu.edu. 


\title{
EXPOSURE ASSESSMENT OF ASTHMA AND MODELING OF PM ${ }_{2.5}$ DURING THE 2007 SOUTHERN CALIFORNIA WILDFIRES
}

\author{
A Thesis \\ Presented to \\ The Faculty of the Department of Meteorology and Climate Science \\ San José State University
}

\author{
In Partial Fulfillment \\ of the Requirements of the Degree \\ Master of Science
}

by

Areana Flores

December 2016 
(C)2016

Areana Flores

ALL RIGHTS RESERVED 
The Designated Thesis Committee Approves the Thesis Titled

EXPOSURE ASSESSMENT OF ASTHMA AND MODELING OF PM P.5 DURING THE 2007 SOUTHERN CALIFORNIA WILDFIRES

By

Areana Flores

\section{APPROVED FOR THE DEPARTMENT OF METEOROLOGY AND CLIMATE SCIENCE}

\section{SAN JOSÉ STATE UNIVERSITY}

December 2016
Dr. Martin Leach
Department of Meteorology and Climate Science
Dr. Frank Freedman Department of Meteorology and Climate Science
Dr. Craig Clements Department of Meteorology and Climate Science 


\section{ABSTRACT \\ EXPOSURE ASSESSMENT OF ASTHMA AND MODELING OF PM 2.5 DURING THE 2007 SOUTHERN CALIFORNIA WILDFIRES \\ By Areana Flores}

A three-year study (1 Jan 07 to 31 Dec 09) was conducted for Los Angeles and Riverside counties to validate current findings on impacts of wildfires on respiratory health. A dataset developed from multiple sources containing daily rates of air pollution $\left(\mathrm{O}_{3}, \mathrm{NO}_{2}, \mathrm{CO}\right.$, and $\left.\mathrm{PM}_{2.5}\right)$ and meteorological variables (temperature, dew point, wind speed, and inversion height) was correlated with asthma emergency department (ED) visits. A second correlation was calculated for a modified dataset that excludes all episodes of wildfire events within the study period. The difference in correlations between both datasets was computed. $\mathrm{PM}_{2.5}$ was positively associated with asthma ED visits during Fall 2007 and its correlation differed significantly between the original and modified datasets. Using CALMET/CALPUFF/WRF from BlueSky’s air modeling framework, the October 2007 wildfires in Southern California were simulated to evaluate and assess the accuracy of $\mathrm{PM}_{2.5}$ concentrations produced by the models. WRF meteorological fields were used as a first guess for input to the CALMET diagnostic meteorological model. This study attempts to improve on the Jackson et al. 2006 study by using a CALMET/WRF hybrid, as WRF is a more physically advanced model than MM5. A sensitivity analysis was performed for the four terrain adjustment schemes. In conclusion, results from this model framework proved to be accurate within $10 \mu \mathrm{g} / \mathrm{m}^{3}$ on October $24^{\text {th }}$ for all schemes, but varied for other dates. After October $26^{\text {th }}, \mathrm{PM}_{2.5}$ underestimations may have resulted from excluding emissions from San Diego wildfires. 


\section{ACKNOWLEDGEMENTS}

I would like to acknowledge my main advisors Dr. Martin Leach and Dr. Frank Freedman who were patient and always readily available. I had this idea for a project and I could not have completed it without their guidance and support. They taught me what is required and expected as a scientist, a skill that has been polished during my years at San Jose State.

I also want to thank my coworker Dr. Tzu-Sai Soong who not only took his time to reviewed and advised me on my thesis, but gave me wise words of encouragement "You are young, you have many more years ahead of you so take your time and don't stress. There is no rush, just look at me (72-years old)."

Moving to a new city and getting through grad school would not have been easy if it wasn't for the constant support of Diana Centeno, Jack Keovongsa, Laura Hodgens, Kelly McDonnell, Trent Smith and family, and many others from the Meteorology and Climate Science Department.

Lastly, I want to thank my family for being understanding and supportive of my decisions to pursue higher education. My mother Elvira Flores, father Jose Flores, siblings Maura, Jose Jr., and Edgar. You guys are my backbone and continuous motivation.

This work was part of a collaborative study funded by the NASA Applied Sciences Program/Public Health Program (grant\# NNX09AV81G). 


\section{TABLE OF CONTENTS}

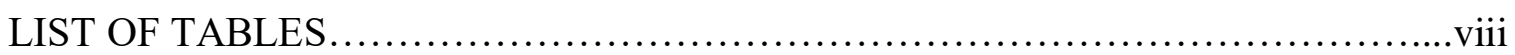

LIST OF FIGURES .........................................................

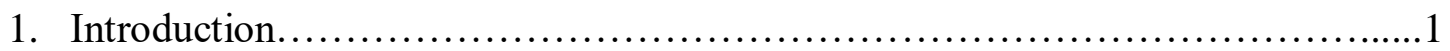

1.1 Weather Conditions on Air Quality and Health Effects...................2

1.2 Health Effects of Wildfires......................................... 3

1.3 Wildfire Modeling................................................5

1.4 Objective and Study Design.........................................6

2. Methods: Statistics and Data............................................

2.1 Exposure Assessment.............................................

2.2 Synoptic Weather Data........................................9

2.3 Data Sources...................................................... 9

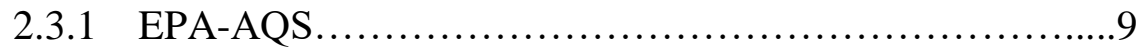

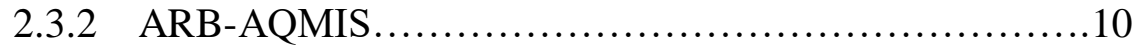

2.3.3 NOAA-NCEI......................................10

2.3.4 NLDAS-CDC WONDER ..........................10

2.3.5 UW-Department of Atmospheric Science................11

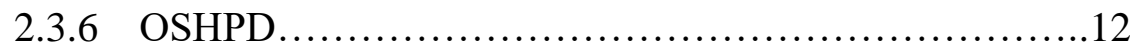

2.4 Population Data Collection....................................... 12

2.5 Statistical Software .............................................. 13 
3. Methods: Modeling .................................................. 13

3.1 Modeling Template............................................. 13

3.2 Model Domain.................................................15

3.3 Fire Emissions................................................ 16

3.4 Meteorology.................................................. 17

3.5 Smoke Concentration and Trajectory Model.............................19

3.6 Development of $\mathrm{PM}_{2.5}$ Concentration Scenarios.........................20

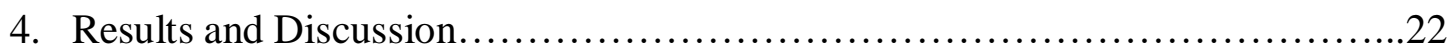

4.1 2007-2009 Asthma Emergency Department Data Analysis..............22

4.2 Data Correlations..............................................24

4.3 Ground Observations for $\mathrm{PM}_{2.5 \ldots \ldots \ldots \ldots \ldots \ldots \ldots \ldots \ldots \ldots \ldots \ldots \ldots \ldots \ldots \ldots \ldots \ldots \ldots \ldots \ldots \ldots}$

4.4 Meteorological Conditions........................................ 31

4.5 GIS and CALPUFF Modeling.....................................43

5. Conclusion and Future Work............................................ 58

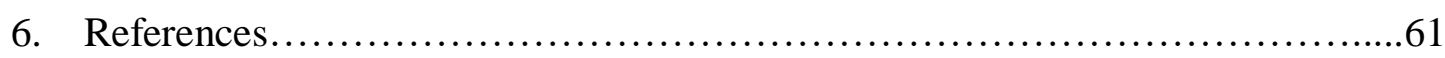

7. APPENDIX A: MODELS AND ACRONYMS ...............................67 


\section{LIST OF TABLES}

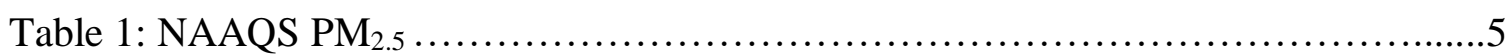

Table 2: BlueSky Smoke Modeling Framework pathway..........................14

Table 3: Average Asthma ED visits per ten million people by year....................23

Table 4: Los Angeles and Riverside correlation differences (2007-2009)...............25

Table 5: Los Angeles and Riverside correlation differences (2007)...................26

Table 6: Los Angeles and Riverside correlation differences $(9 / 1 / 0711 / 31 / 07) \ldots \ldots \ldots \ldots . .27$ 


\section{LIST OF FIGURES}

Fig. 1: NASA/MODIS Terra Satellite passing over Southern California (10/23/07 1925 UTC)

Fig. 2: Terrain elevations and land use over CALPUFF domain... 15

Fig. 3: Location of Land-Based weather stations and terrain elevation .19

Fig. 4: Location of discrete receptors and terrain elevation. .22

Fig. 5: Time series of Asthma ED visits Los Angeles and Riverside (2007-2009) .23

Fig. 6: Time series of surface average $\mathrm{PM}_{2.5}$ Los Angeles and Riverside (2007-2009) .24

Fig. 7: Scatter plot $\mathrm{PM}_{2.5}$ and asthma ED visits Los Angeles (9/1/07-11/31/07). .28

Fig. 8: Scatter plot $\mathrm{PM}_{2.5}$ and asthma ED visits Riverside (9/1/07-11/31/07).

Fig. 9: Time series of surface average $\mathrm{PM}_{2.5}$ Los Angeles and Riverside (Oct. 2007) 30

Fig. 10: Vertical temperature profile (10/23/07 1200 UTC). 31

Fig. 11: NCEP 500-millibar and surface analysis (10/23/07 1200 UTC) .33

Fig. 12: NCEP 500-millibar and surface analysis (10/24/07 1200 UTC) , 34

Fig. 13: NCEP 500-millibar and surface analysis (10/25/07 1200 UTC) .35

Fig. 14: NCEP 500-millibar and surface analysis (10/26/07 1200 UTC) .36 
Fig. 15: Time series surface daily max temperature and dew point (Oct. 2007)

Fig. 16: CALMET 10-meter wind vectors (10/20/2007 1900 UTC)...................39

Fig. 17: CALMET 10-meter wind vectors (10/21-10/23 1900 UTC) .................40

Fig. 18: CALMET 10-meter wind vectors (10/25-10/27 1900 UTC)...................42

Fig. 19: GIS wildfire footprints for Southern California $(10 / 20-10 / 31) \ldots \ldots \ldots \ldots \ldots \ldots . . .43$

Fig. 20: NASA Terra Satellite over Southern California $(10 / 23-10 / 24) \ldots \ldots \ldots \ldots \ldots \ldots \ldots . . .44$

Fig. 21: NASA Terra Satellite over Southern California $(10 / 25-10 / 26) \ldots \ldots \ldots \ldots \ldots \ldots \ldots . . . \ldots 5$

Fig. 22: 1-hour averaged total emissions CALPUFF all schemes $(10 / 23 / 07) \ldots \ldots \ldots \ldots . . .46$

Fig. 23: 1-hour averaged total emissions CALPUFF all schemes $(10 / 24 / 07) \ldots \ldots \ldots \ldots . . .47$

Fig. 24: 1-hour averaged total emissions CALPUFF all schemes $(10 / 25 / 07) \ldots \ldots \ldots \ldots . . .48$

Fig. 25: 1-hour averaged total emissions CALPUFF all schemes $(10 / 26 / 07) \ldots \ldots \ldots \ldots . . .49$

Fig. 26: 24-hour averaged time series observed and modeled $\mathrm{PM}_{2.5}$ concentrations Anaheim (10/21/07-10/27/07) ......................................51

Fig. 27: 24-hour averaged time series observed and modeled $\mathrm{PM}_{2.5}$ concentrations Los Angeles (10/21/07-10/27/07) ...................................52

Fig. 28: 24-hour averaged time series observed and modeled $\mathrm{PM}_{2.5}$ concentrations Long Beach $(10 / 21 / 07-10 / 27 / 07)$...................................53

Fig. 29: 24-hour averaged time series observed and modeled $\mathrm{PM}_{2.5}$ concentrations Rubidoux $(10 / 21 / 07-10 / 27 / 07)$.........................................54 
Fig. 30: 24-hour average $\mathrm{PM}_{2.5}$ GIS plot observed values $(10 / 23 / 07) \ldots \ldots \ldots \ldots \ldots \ldots . \ldots 55$

Fig. 31: 24-hour average $\mathrm{PM}_{2.5}$ GIS plots No Adjustment and ISC Adjustment

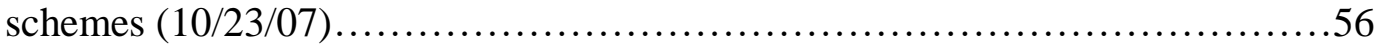

Fig. 32: 24-hour average $\mathrm{PM}_{2.5}$ GIS plots CALPUFF and Partial Plume Path

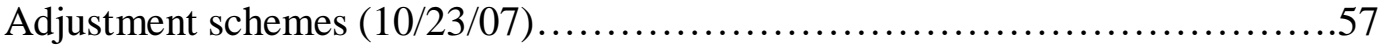




\section{Introduction}

Atmospheric conditions, including air quality and weather, influence the response of the human respiratory system. The frequency and duration of exposure to the detrimental effects of poor air quality depend on factors such as current weather conditions, location, topography, climate, and socioeconomic status. Continuous exposure to poor air quality has been linked to impairment of normal lung growth and development of diseases such as asthma (Peden 2005). Air pollutants and meteorological conditions have been found to be correlated with exacerbation of acute respiratory tract illnesses (Peden 2005), that can sometimes lead to emergency department (ED) visits or hospital admissions.

Asthma is a chronic inflammatory disorder of the airways characterized by repeated incidents of impaired breathing when the airways become congested. Approximately 26 million Americans are diagnosed with asthma, the third leading cause of hospitalization among children (American Lung Association 2014). Asthma episodes tend to occur with certain conditions and vary from one asthmatic to the next as well within the same individual over time. Common conditions, or triggers, of asthma attacks include physical activity, air pollution, infections, house dust, animal allergens, pollen allergens, and psychological factors such as watching an emotional film (Ritz et al. 2006).

During the autumn in Southern California, hot and dry westerly Santa Ana winds following a dry summer creates the optimal conditions for wildland fires. Fire season 
varies yearly depending on weather patterns, moisture content, and vegetation present and usually ends with the onset of cooler weather and precipitation (Phuleria et al. 2005).

In the Fall of 2007, California endured wildfires that burned approximately 970,977 acres (“California Fire Siege 2007: An Overview” 2008). The strong, dry Santa Ana winds dispersed smoke plumes towards the Los Angeles basin, where a large urban population was exposed to elevated concentrations of air pollutants from the fires. Past results show that quantitatively the area burned per day is 3.5-4.5 times larger on Santa Ana days than on non-Santa Ana days with relative humidity having the strongest correlation with burned area per day (Billmire et al. 2014).

In general, the Los Angeles basin is a coastal lowland area, surrounded by high mountains. The topography and common temperature inversions lead to the accumulation of airborne pollutants, predominantly in the eastern region of the basin, due to the prevailing westerly sea breeze (Lu et al. 1996).

\subsection{Weather Conditions on Air Quality and Health Effects}

Meteorological conditions affect the oxidation of air pollutants in the atmosphere. Ozone concentrations peak in the summer months when temperatures are warmest and have been shown to exacerbate asthma (Cody et al. 1992). White et al. (1994), found that the average number of visits for children in Atlanta with asthma or reactive airway disease was $37 \%$ higher on the days following a 6-day period in which maximum ozone levels equaled or exceeded $0.11 \mathrm{ppm}$.

Atmospheric inversions during winter time trap pollutants, increasing the concentrations of particulate matter. The smallest particulates caused by wood burning 
during this time penetrate deep in the lung triggering asthmatics. Passage of a cold front tends to be followed by stagnant, rain-free conditions which helps retain airborne particles and has resulted in asthma epidemics (Goldstein 1980). In three separate studies lower air temperature and lower absolute and relative humidity resulted in higher ED visits for asthma (Carey and Cordon 1986; Abe et al. 2009; Nastos et al. 2008). However, in a study by Mireku et al. (2009), significant increases in relative humidity and temperature were associated with additional ED visits for asthma.

After standardizing for temperature, $\mathrm{NO}_{2}$ concentrations were found to be correlated significantly with hospital attendances for asthma (Rossi et al. 1993). Girsh et al. (1966), found a threefold increase of bronchial asthma in children in Philadelphia during "noteworthy" air pollution days, days during which pollutant concentration scored above the highest tenth percentile of scores observed during the 2-year study period. In addition, a fourfold increase in asthma hospital visitations occurred on days when barometric pressure exceeded $1020 \mathrm{hPa}$ for a 24-hour period. When the conditions coincided, there was approximately a nine-fold increase in attacks for bronchial asthma.

\subsection{Health Effects of Wildfires}

Wildfires can have mental and physical effects on humans while also affecting the environment. For example, news of an inherently unpredictable force of nature in itself can induce psychosocial stress in the population (Kumagai et al. 2004). Pregnancy during a wildfire event can lead to slightly reduced average birth weight among infants exposed in utero (Holstius et al. 2012). Exposure to wildfire smoke is associated with 
increased eye and respiratory symptoms, medication use, and physician visits (Künzli et al. 2006).

However, the most significant health-related pollutant from wildfire events is particulate matter (PM) (Naeher et al. 2007). Air pollutants released during a wildfire such as particulate matter with aerodynamic diameter of less than $10 \mu \mathrm{m}\left(\mathrm{PM}_{10}\right)$, fine particulate matter with aerodynamic diameter of less than $2.5 \mu \mathrm{m}\left(\mathrm{PM}_{2.5}\right)$, carbon monoxide $(\mathrm{CO})$, and sulfur dioxide $\left(\mathrm{SO}_{2}\right)$, can directly affect the respiratory system. US Environmental Protection Agency (USEPA) set National Ambient Air Quality Standards (NAAQS) for $\mathrm{PM}_{10}$ in 1989 and more recently adopted new standards for primary and secondary $\mathrm{PM}_{2.5}$ seen in Table 1 . Most of the $\mathrm{PM}_{2.5}$ mass consists of the condensed products of either atmospheric chemical reactions and incomplete combustion. Epidemiologic studies have shown a correlation between PM exposure and asthma exacerbation (Nemmar et al. 2002; Penttinene et al. 2001; Utell and Frampton 2000). Due to their small size, once inhaled they penetrate deep into the lungs whereas larger size PM ends up deposited in the upper airways. Inhaled ultrafine particles diffuse rapidly into the systematic circulation, inducing oxidative stress and mitochondrial damage, relevant for the cardiovascular morbidity and mortality related to ambient particle pollution (Li et al. 2003; Nemmar et al. 2002).

Concentrations of PM are higher during wildfire episodes and more toxic to the lung than PM collected from normal ambient air in the same region (Wegesser et al. 2009). One study found that during the 2003 Southern California wildfires (21-30 October), 2-day average $\mathrm{PM}_{2.5}$ was associated with respiratory admissions that were 
greater during than before or after the fires. Average increases of $70 \mu \mathrm{gm}^{-3} \mathrm{PM}_{2.5}$ during heavy smoke conditions compared with $\mathrm{PM}_{2.5}$ in the pre-wildfire period were associated with $34 \%$ increases in asthma admissions (Delfino et al. 2009). While the primary cause for exacerbated asthma during a wildfire event is due to the air pollution effects, comparing the possibilities mentioned earlier is scientifically complex when determining quantitatively how wildfire pollution correlates to increased asthma exacerbations.

Table 1. NAAQS PM 2.5

\begin{tabular}{|c|c|c|c|c|}
\hline Pollutant & Primary/Secondary & Averaging Time & Level & Form \\
\hline \multirow[t]{3}{*}{$\mathrm{PM}_{2.5}$} & Primary & 1 year & $12.0 \mathrm{ug} / \mathrm{m} 3$ & Annual mean, averaged over 3 years \\
\hline & Secondary & 1 year & $15.0 \mathrm{ug} / \mathrm{m} 3$ & Annual mean, averaged over 3 years \\
\hline & Primary and secondary & 24 hours & $35 \mathrm{ug} / \mathrm{m} 3$ & $98^{\text {th }}$ percentile, averaged over 3 years \\
\hline
\end{tabular}

\subsection{Wildfire Modeling}

In a separate 2003 Southern California wildfire study, Phuleria et al. (2005), looked at averages of criteria pollutants in the Los Angeles basin before, during, and after the wildfire outbreak and found that coarse-particle mass concentrations measured at sampling sites downwind of the fires were 3-4 times higher than typical background concentrations. This is one example of a method used to assess air quality impacts from wildfires using ground observations. However, in order to evaluate pollutant concentrations from fires separate from background levels, further analysis and modeling is essential. Choi et al. (2007), presented a methodology that calculated PM by simulating smoke plumes from agriculture burns using the CALPUFF/CALMET/MM5 modeling system. Wiedinmyer et al. (2006), developed a modeling framework to estimate the 
emissions from fires in North and parts of Central America by combining complementary satellite and ground-based data.

The BlueSky modeling framework offers numerous pathways for running thirdparty models for the production and simulation of emissions, transport, and chemistry of smoke from fires (Larkin et al. 2009). Weather model output and fire information is run through a sequence of modeling steps in order to generate smoke trajectory and concentrations. Strand et al. (2012), used the BlueSky Gateway modeling system to evaluate predictions of $\mathrm{PM}_{2.5}$ surface concentrations during the 2007 Southern and 2008 Northern California fires. BlueSky has been coupled with SMARTFIRE (Raffuse et al. 2009), and SMOKE (Houyoux et al. 2000), in ongoing research for the US Forest Service, US EPA, and NOAA to improve the wildland fire emissions inventory (Pouliot et al. 2005; Sullivan et al. 2008).

\subsection{Objectives and Study Design}

A three-year study using data from 2007 to 2009 was conducted for the California counties of Los Angeles and Riverside. Given that air pollution is a trigger in respiratory sensitivity, this study focused on periods when air pollution concentrations were elevated to validate current findings between asthma exacerbation and $\mathrm{PM}_{2.5}$. We first look for trends in county level population who required medical attention for asthma. A dataset that includes daily rates of air pollution and meteorological variables was correlated with asthma emergency department visits. A second correlation was calculated for a new dataset that excludes all episodes of wildfire events within the study period. All statistically significant differences in both datasets were noted. 
Using the CALMET/CALPUFF/WRF pathway from BlueSky's air modeling framework, the October 2007 wildfires in Southern California were simulated to evaluate and assess the accuracy of $\mathrm{PM}_{2.5}$ concentrations produced by the pathway. WRF meteorological fields were used as a first guess into the CALMET meteorological model, adjusting the meteorological fields to more realistically reflect land use and higher terrain. To further enhance the simulation, CALMET incorporates ground observations.

A previous study by Jackson et al. 2006 found that simulating ozone concentrations using the CALMET/MM5 hybrid resulted in better agreement with observed concentrations than those simulated using only MM5 generated inputs. This study attempts to improve on the Jackson et al. (2006), study by using a CALMET/WRF hybrid, as WRF is a more physically advanced model than MM5.

\section{Methods: Statistics and Data}

\subsection{Exposure Assessment}

Meteorological variables and criteria pollutants that have potential respiratory impact were considered to analyze emergency department (ED) visits due to asthma. The data used for the analysis included daily ozone $\left(\mathrm{O}_{3}\right)$, nitrogen dioxide $\left(\mathrm{NO}_{2}\right)$, carbon monoxide (CO), particulate matter with diameter less than 2.5 microns $\left(\mathrm{PM}_{2.5}\right)$, temperature, dew point, wind speed, inversion height, and asthma count per county.

Daily time series plots for each of the variables were evaluated for trends. Correlations between asthma and all variables were conducted for the entire period from 2007 through 2009, for each individual year, and for annual season where winter is December, January, February, spring is March, April, May, summer is June, July, 
August, and fall is September, October, November. The highest seasonal correlations were reviewed further. Los Angeles and Riverside counties were chosen for comparison based on the correlations and population density.

Wildfire events have the greatest short-term impact on air quality. Wildfires were strategically excluded from the dataset, which will now be known as the modified dataset, using set rules for open burn programs by the air district. Open burn programs in California are designed to ensure that open burning is conducted in a manner that minimizes emissions and impacts, and that smoke is managed consistent with state and federal law in order to protect public health and safety. Rule 444-Open Burning from South Coast Air Quality Management District (SCAQMD) states that the Executive Officer may allow the maximum daily burn acreage of 175 for prescribed wildland and range burning for all areas within the district jurisdiction. Using Rule 444 as a guide, all fires greater than 175 acres were eliminated from the dataset. This was conducted by excluding the rows whose date fell within that specific wildfire event, with some events overlapping. Correlations were once again re-calculated.

Wildfires that occurred between 2007 and 2009 and exposed significant threat to communities surrounding Los Angeles and Riverside counties transpired during the fall seasons (CAL FIRE). One such wildfire event occurred between 20 and 31 October 2007 burning more than 100,000 acres (Fig. 1). This time period was used in the modeling of wildfires and exposure assessment. 


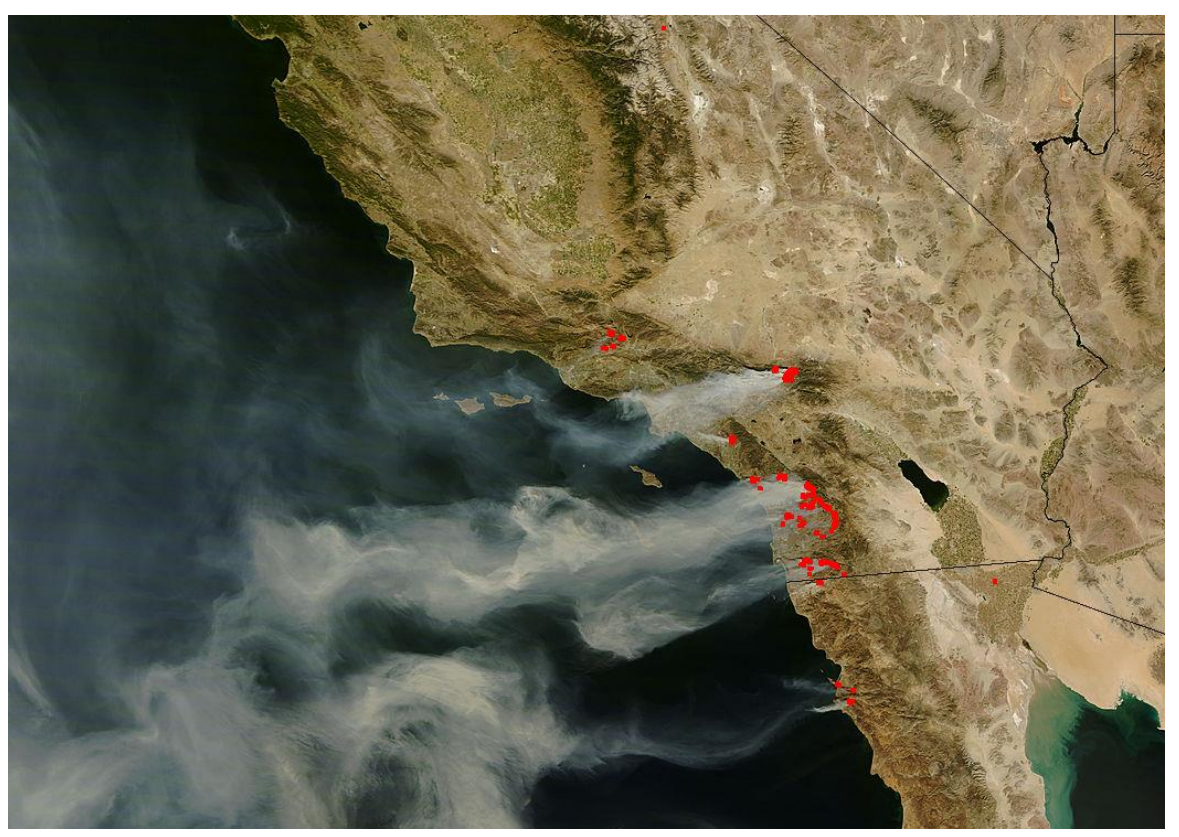

Fig. 1. NASA/MODIS Terra Satellite passing over Southern California 23 October 2007 1925 UTC.

\subsection{Synoptic Weather Data}

Daily weather maps from the National Centers for Environmental Predictions (NCEP) Weather Prediction Center were used for synoptic analysis of the observed meteorological conditions.

\subsection{Data Sources}

\subsubsection{EPA-AQS}

Criteria pollutant data acquired from the Air Quality System (AQS) database through the Environmental Protection Agency (EPA) included: daily max 1-hour nitrogen dioxide measured in parts per billion $\left(\mathrm{NO}_{2}\right)(\mathrm{ppb})$; daily max 8-hour ozone measured in parts per million $\left(\mathrm{O}_{3}\right)$ (ppm); and daily max 8-hour carbon monoxide measured in parts per million (CO) (ppm). 
All measuring sites fall under the state or local air monitoring stations (SLAMS) network. The SLAMS network comprises of ambient air quality monitoring sites that are operated by state or local agencies for comparison to the NAAQS.

\subsubsection{ARB-AQMIS}

Maximum dew point temperature $\left({ }^{\circ} \mathrm{F}\right)$ was acquired from the California Air Resources Board (ARB) Air Quality and Meteorological Information System (AQMIS) database. Meteorological data provided through ARB was collected from various outside sources and staff conducted preliminary quality assurance. Stations chosen for data retrieval were University of Southern California (USC), CA and Riverside Municipal Airport (RMA), CA. These sites best represented our area of study due to their central location in each county respectively.

\subsubsection{NOAA-NCEI}

Fastest 2-minute sustained wind speed $\left(\mathrm{ms}^{-1}\right)$ was retrieved from NOAA's National Centers for Environmental Information (NCEI) for the USC and RMA sites.

NCEI is responsible for hosting and providing access to comprehensive oceanic, atmospheric, and geophysical data. NCEI's Center for Weather and Climate acquires, preserves, monitors, and assesses historical weather data and information (NCEI, 2016).

\subsubsection{NLDAS-CDC WONDER}

Data obtained through The North America Land Data Assimilation System (NLDAS) from the Centers for Disease Control Wide-ranging Online Data for Epidemiologic Research (CDC WONDER) database included county-level maximum air temperature $\left({ }^{\circ} \mathrm{F}\right)$ and outdoor daily average fine particulate matter $\left(\mu \mathrm{gm}^{-3}\right)$. 
The modified regional surfacing algorithm of Al-Hamdan et al. (2009), used EPA AQS PM $\mathrm{PM}_{2.5}$ measured in micrograms per cubic meter $\left(\mu \mathrm{gm}^{-3}\right)$ in-situ data and NASA MODIS aerosol optical depth remotely sensed data. Using a geographic information system (GIS) they identified the associated geographic locations of the centroids of the gridded $\mathrm{PM}_{2.5}$ datasets, by county and state, to enable aggregation to different geographic levels in CDC WONDER. County-level data aggregated from 10-kilometer square spatial resolution grids were used. The data used in CDC WONDER were acquired as part of the mission of NASA's Earth Science Division and archived and distributed by the Goddard Earth Sciences (GES) Data and Information Services Center (DISC).

\subsubsection{UW-Department of Atmospheric Science}

Raw radiosonde data from the University of Wyoming Department of Atmospheric Science was used to calculate the inversion height. The maximum mixing depth is calculated using the following equation:

$$
I H=\frac{\Delta \theta}{\Delta Z}
$$

where $\theta$ is potential temperature in degrees Kelvin and $\mathrm{Z}$ is geopotential height in meters. Radiosonde data produces a vertical profile of temperature, moisture and wind shear between 200 and $850 \mathrm{hPa}$. To understand the dispersion of pollutants in the lower

atmosphere it is essential to determine the depth of the mixing layer where $\frac{\Delta \theta}{\Delta Z}>0$, the height at which the atmospheric temperature reverses its profile. The greater the height, also known as the maximum mixing depth, the larger the volume of atmosphere that is available to dilute the pollutant concentration. 


\subsubsection{OSHPD}

Data on emergency department (ED) visits for asthma by county, day, and type for the years 2007 to 2009 for all ages was obtained from the Office of Statewide Health Planning and Development (OSHPD) database. The ED data set includes information from hospitals licensed to provide emergency medical services. The ED visits included those patients who had face-to-face contact with the provider. Per legislation, hospitals are required to report patient data to OSHPD using the Medical Information Reporting for California manual to ensure quality of data. In healthcare, diagnoses codes are used to classify diseases, illnesses and injuries known as the International Statistical Classification of Diseases and Related Health Problems (ICD). For this study the type of diagnoses for asthma with their respective ICD code were extrinsic (493.00, 493.01, 493.02), intrinsic $(493.10,493.11,493.12)$, chronic $(493.20,493.21,493.22)$, other (493.81, 493.82), and unspecified $(493.90,493.91,493.92)$. The daily sum for all types of asthma was calculated and imported to the dataset.

\subsection{Population Data Collection}

Data on population estimates by county were obtained and produced by the State of California Department of Finance Demographic Research Unit. The data file provides population estimates by single years of age, gender, race for California and its counties. These estimates were for the time period of July 1, 2000 through 2010. A baseline cohort-component method was used to estimate population by age, gender, and race (Department of Finance, 2012). The sum of population estimates was calculated per county per year for the years 2007, 2008, and 2009. 


\subsection{Statistical Software}

MATLAB version $\mathrm{R} 2014 \mathrm{a}$ and the $\mathrm{RHO}=\mathrm{CORR}(\mathrm{X}, \mathrm{Y})$ function was used to perform a pairwise linear correlation coefficient between each pair of columns in the dataset.

In addition, the CORREL function under the EXCEL Data Analysis Tool was used. The correlation analysis tool examines each pair of measurement variables to determine whether the two measurement variables tend to move together - that is, whether large values of one variable tend to be associated with large values of the other (positive correlation), whether small values of one variable tend to be associated with large values of the other (negative correlation), or whether values of both variables tend to be unrelated (correlation near 0 (zero)). The value of any correlation coefficient must be between -1 and +1 inclusive.

A two-tail Pearson correlation significance test was performed to calculate $P$ values.

\section{Methods: Modeling}

\subsection{Modeling Template}

The BlueSky smoke modeling framework (Table 2), was utilized to model both the meteorology and pollutant dispersion and transport of the wildfires. BlueSky is a modular framework that integrates existing datasets and models into a uniform structure. It enables a user to compare models. If ran as a complete system, it needs meteorological data, fire location, and size to produce smoke concentrations and trajectories (Larkin et al. 2009). BlueSky has been adopted by various government agencies to predict smoke 
from wildfires and has been used as a decision-making tool for prescribed burns. The framework has also been used for air quality forecasting.

BlueSky requires four-dimensional $(\mathrm{x}, \mathrm{y}, \mathrm{z}, \mathrm{t})$ meteorological information, daily fire growth, and fire location (longitude, latitude). Additional information can be manually inserted, overriding default model settings. Once fire information is loaded into the framework, fuel loadings and moisture conditions are determined, consumption is calculated, and the emissions from the consumption are speciated and allocated diurnally (Larkin et al. 2009). The results are then used to run the dispersion or trajectory models. The following sections describe the models used for the October 2007 wildfires as seen in Table 2.

Table 2. BlueSky Smoke Modeling Framework pathway

\begin{tabular}{|c|c|}
\hline PATH NAME & MODEL \\
\hline METEOROLOGY & $\begin{array}{l}\text { Advanced Weather Research and Forecasting Model (WRF-ARW) v3.4 } \\
\text { [Shamarock et al. 2008] } \\
\text { CALMET [Scire et al. 2000b] }\end{array}$ \\
\hline FIRE INFORMATION & US Incident Command System (ICS)-209 Incident Status Summary \\
\hline FUEL LOADING & $\begin{array}{l}\text { US National Fire Danger Rating Systems (NFDRS) [Cohen and Deeming } \\
\text { 1985] }\end{array}$ \\
\hline FUEL CONSUMED & Fire Emissions Production Simulator v1 (FEPS) [Anderson et al., 2004] \\
\hline TIME PROFILE & FEPS \\
\hline EMISSIONS & FEPS \\
\hline $\begin{array}{l}\text { SMOKE CONC. \& } \\
\text { TRAJECTORY }\end{array}$ & CALMET-CALPUFF v.8.2 [Scire et al. 2000b] \\
\hline
\end{tabular}




\subsection{Model Domain}

The area of interest over Southern California is depicted in Fig. 2. The horizontal CALPUFF modeling domain in UTM coordinates was centered at $11 \mathrm{~N} 419.981 \mathrm{~km} \mathrm{E}$, $3764.959 \mathrm{~km} \mathrm{~N}$ with size $183 \times 157 \mathrm{~km}^{2}$.

a)
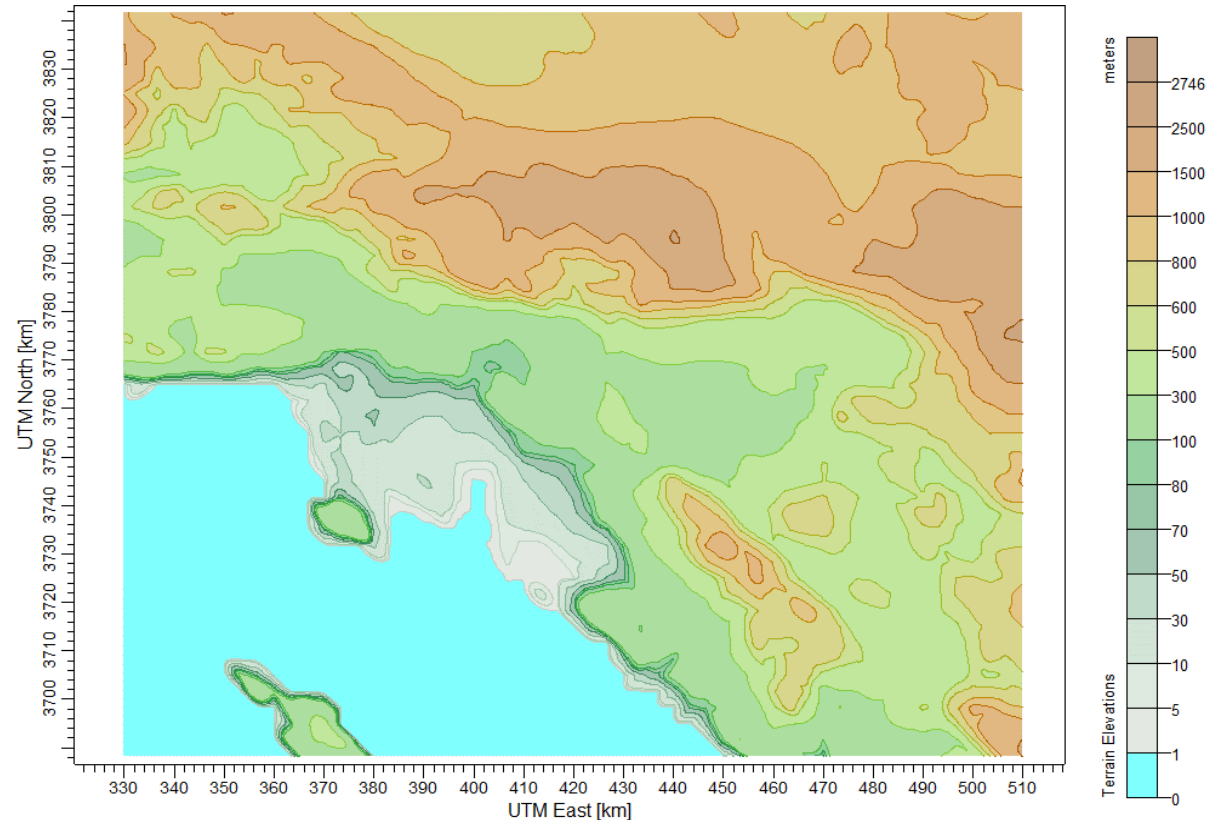

b)
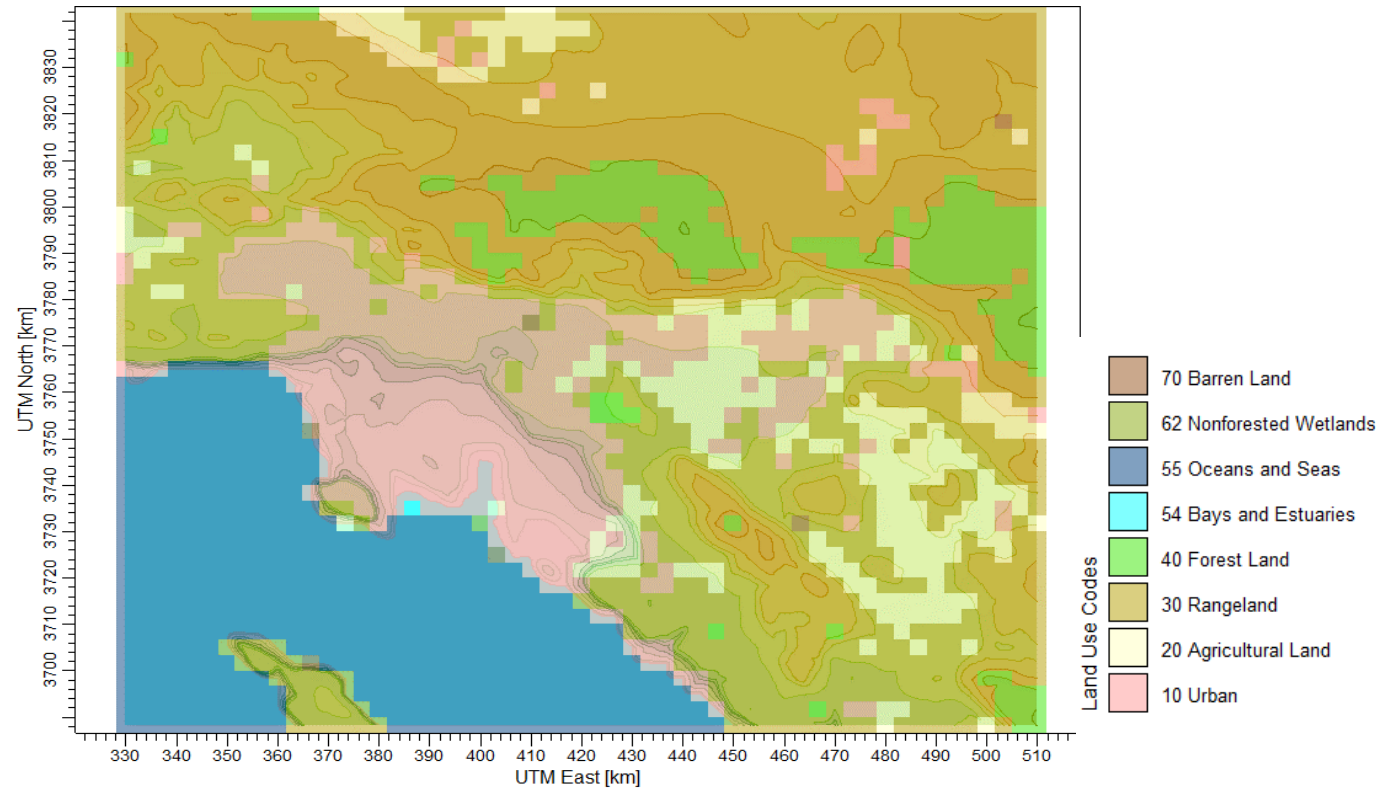

Fig. 2. (a) Terrain Elevations and (b) Land Use with terrain elevation over CALPUFF domain 


\subsection{Fire Emissions}

The Fire Emissions Production Simulator, version 1 (FEPS) [Anderson et al. 2004], was used to estimate emissions of trace gases and particulate matter from wildland fires that occurred during the October 2007 fire outbreak. The model manages data concerning consumption, emissions, and heat release characteristics of prescribed burns and wildland fires (Anderson et al. 2004). Total fuels consumption values are distributed over the life of the fire to generate hourly emission and release information.

FEPS can be used for most forest, shrub and grassland types in North America and the world. A list of fuel loading profiles based on the National Fire Danger Rating System (NFDRS) [Cohen and Deeming, 1985], is provided. The NFDRS is a model that allows for predictions of potential fire danger. It combines the effects of existing and expected states of selected fire danger factors into one or more qualitative or numeric indices that reflect an area's fire protection needs (USDA Forest Service, 2016). Fuels, weather, topography, and risks are main inputs into the NFDRS model. For our purposes, Fuel Model B best represented the setting of our domain. This model is described as mature, dense fields of brush 6 feet or more in height. One-fourth or more of the aerial fuel in such stands is dead and foliage burns instantly. Model B fuels are potentially very dangerous, fostering intense fast-spreading fires. This model is for California mixed chaparral, generally 30 years or older.

To estimate plume rise, FEPS requires cumulative area burned in acres and daily extreme temperature and relative humidity values as input. Wildfire incident information for the state of California was made available through The California Department of 
Forestry and Fire Protection (CALFIRE). Incidents involving any fire under a full suppression management strategy that exceeds 100 acres in timber (fuel models $\mathrm{H}-\mathrm{N}$ ), 300 acres in grass and brush (fuel models A-G), or has a Type 1 or 2 incident management team assigned, require an Incident Status Summary (ICS-209) report. This is provided by the Federal Emergency Management Agency (FEMA) and submitted to the Geographic Area Coordination Center (GACC) that serves the Federal and State wildland fire agencies through logistical coordination and mobilization of resources. Frequency of reporting varies with strategies employed.

Temperature and relative humidity extremes were retrieved from the weather observation data archive through University of Utah's MesoWest network made available by governmental agencies, commercial firms, and educational institutions participating in MesoWest (Horel et al. 2002). Individual station data was provided and only those close to the proximity of the wildfire were selected and used for input to the Fire Emission Production Simulator (FEPS).

FEPS is complementary to CALPUFF for the simulation of fire area source buoyancy. The FEPS buoyancy and emission results file are converted to a Buoyant AREA Source Variable Emissions File (BAEMARB.DAT) for input into CALPUFF.

\subsection{Meteorology}

The Advanced Weather and Research Forecasting Model, Version 3.4 (WRFARW) [Skamarock et al. 2008], was used to generate meteorological fields on a 30km Lambert Conformal horizontal grid with 3 nested domains at dimensions of 43 by 43 for the parent grid, 61 by 61 for the $2^{\text {nd }}$ domain, and 85 by 85 for the $3^{\text {rd }}$ domain. 
The WRF Pre-Processing System (WPS) version 3.4 was used to prepare data for input into the real case program. For the initial and time-dependent lateral boundary conditions, the National Centers for Environmental Prediction (NCEP) North American Mesoscale Forecast System (NAM) 3-hourly reanalysis data at $34.5 \mathrm{~km}$ horizontal resolution was used. The YSU planetary boundary layer scheme was used along with RRTM's longwave radiation scheme and Dudhia (1985), shortwave radiation scheme. The meteorological fields developed by WRF were integrated into CALMET (Scire et al. 2000b). CALMET is a diagnostic meteorological model that interpolates surface observations retrieved from NCEI (Fig. 3), and upper air prognostic data to produce an enhanced wind field. It develops hourly wind and temperature fields on a three-dimensional gridded modeling domain and mixing height, surface characteristics, and dispersion properties on a two-dimensional gridded domain. The data interpolation takes into account terrain effects and ensures the preservation of air-mass continuity (Scire et al., 2000). CALMET is coupled with CALPUFF to develop hourly concentration amounts. The horizontal CALMET modeling domain mirrors the CALPUFF domain with a 3.33-km resolution grid space. Vertically, the domain consisted of 10 fixed-height layers to $4000 \mathrm{~m}$. 

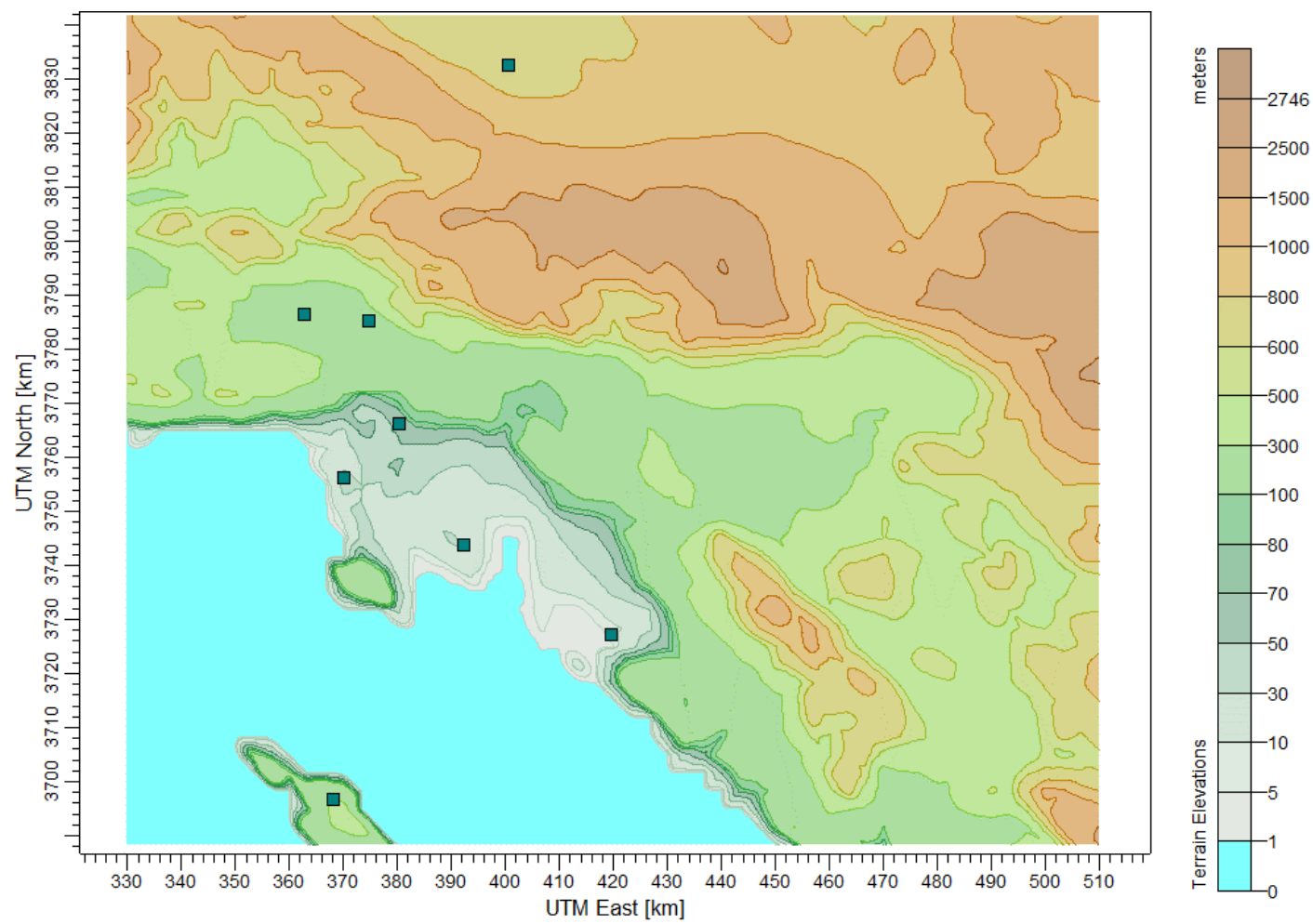

Fig. 3. Location of Land-Based Weather Stations (NCEI) and terrain elevation.

\subsection{Smoke Concentration and Trajectory Model}

California Mesoscale Puff Model (CALPUFF), a multi-layer, multi-species nonsteady-state Lagrangian Gaussian puff dispersion model, adopted and approved by U.S. EPA as a regulatory model of choice, simulates the effects of time and space-varying meteorological conditions on pollution transport, transformation, and removal (Scire et al., 2000). For this study CALPUFF model version 8.2, the latest version, is set to simulate fire as a buoyant area source. This version accounts for effects of vertical wind shear, large initial plume size, and density differences between the plume and ambient air. Continuous puffs of pollutants are released from an area source into the ambient wind flow and as the wind flow changes temporally and spatially, the puff diffuses. As the puff 
travels over a surface receptor point, the receptor simulates the total concentration value from the contribution of multiple puffs.

\subsection{Development of $\mathrm{PM}_{2.5}$ Concentration Scenarios}

The Southern California 2007 wildfire outbreak started the night of 20 October 2007 and lasted through the end of the month ("California Fire Siege: An Overview", 2008). The peak fire-smoke action within the CALPUFF domain occurred between 20 and 27 October 2007. The CALPUFF run was initiated on 20 October 2007 00:00 Local Time (LT) and terminated 28 October 2007 23:00 LT. Species modeled included PM 2.5 , $\mathrm{CO}$, and $\mathrm{CH}_{4}$. No chemical transformation was modeled due to the strict purpose of obtaining $\mathrm{PM}_{2.5}$ concentration values from the wildfires.

The Partial Plume Penetration-Buoyant Area (MPARTLBA) option was selected under the Plume Rise option. For dispersion options (MDISP), the Puff Plume Element Modeling Method was used along with the dispersion coefficient option that uses turbulence computed from micrometeorology. This option internally calculates $\sigma-\mathrm{v}$ and $\sigma-\mathrm{w}$ using input meteorological data from CALMET. No puff splitting or turbulence advection was selected.

A sensitivity analysis was conducted for the four Terrain Adjustment Method options. The terrain adjustment is applied to gridded and discrete receptors and adds variation to the model and consequently its results. The four adjustment schemes and descriptions are as follows:

1. No Adjustment: Holds the puffs at a constant height above the surface, using only 'flat-terrain' calculations. 
2. ISC Terrain Adjustment: Puff remains at 'stack-height'. The distance between the ground and the puff reduces when the terrain rises and all elevations above 'stackheight' are eliminated.

3. CALPUFF Terrain Adjustment: The vertical size of the puff is modified rather than its height above the ground.

4. Partial Plume Path Adjustment: Adjusts puff height based on stability class and local terrain elevation above 'stack-height'. Adjustment coefficient 0.5 is used on the original puff height in non-stable conditions and reduces with increasing stability.

An evaluation of the performance of all four adjustments was made by comparing receptor results, including background values, with measurements from EPA's local monitoring stations. The receptor locations (Fig. 4), were configured using EPA's active site coordinates. 


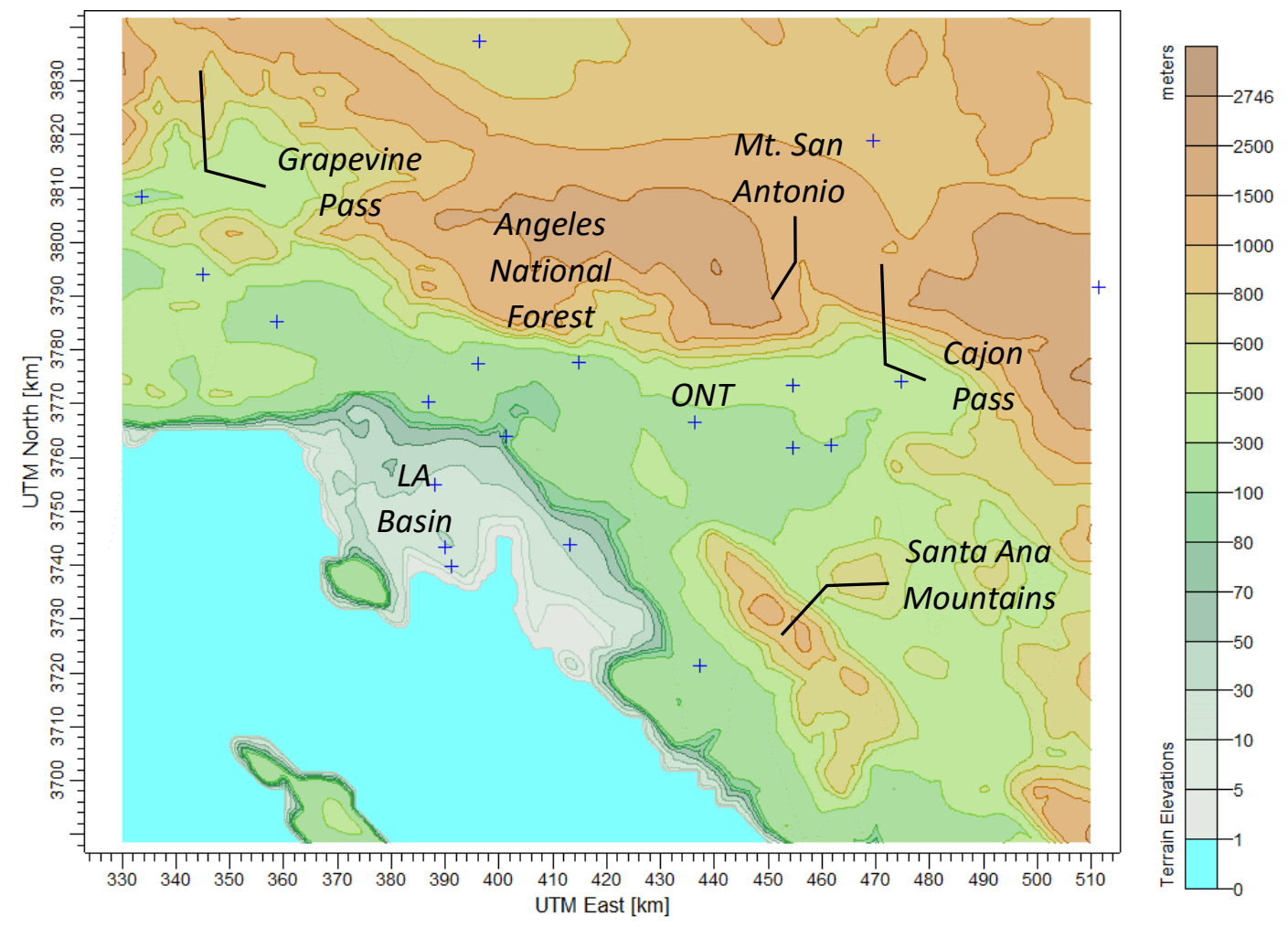

Fig. 4. Location of discrete receptors (+) and terrain elevation.

\section{Results and Discussion}

\subsection{7-2009 Asthma Emergency Department Data analysis}

Fig. 5 depicts daily time series plots for asthma ED visits per ten million people for Los Angeles and Riverside counties. As shown in the graph, asthma follows an evident seasonal pattern in which asthma rates are higher in the fall and winter and lower during the spring and summer with Riverside having greater variability. For Los Angeles, asthma counts ranged between 34 and 245 while for Riverside they ranged between 19 and 227. A maximum of 215 occurred on 24 October 2007 in Los Angeles and 202 on 27 October 2007 for Riverside. The average for each year is shown in Table 3. It is clear that between 2007-2009, the averages for asthma ED visits increased over time. 

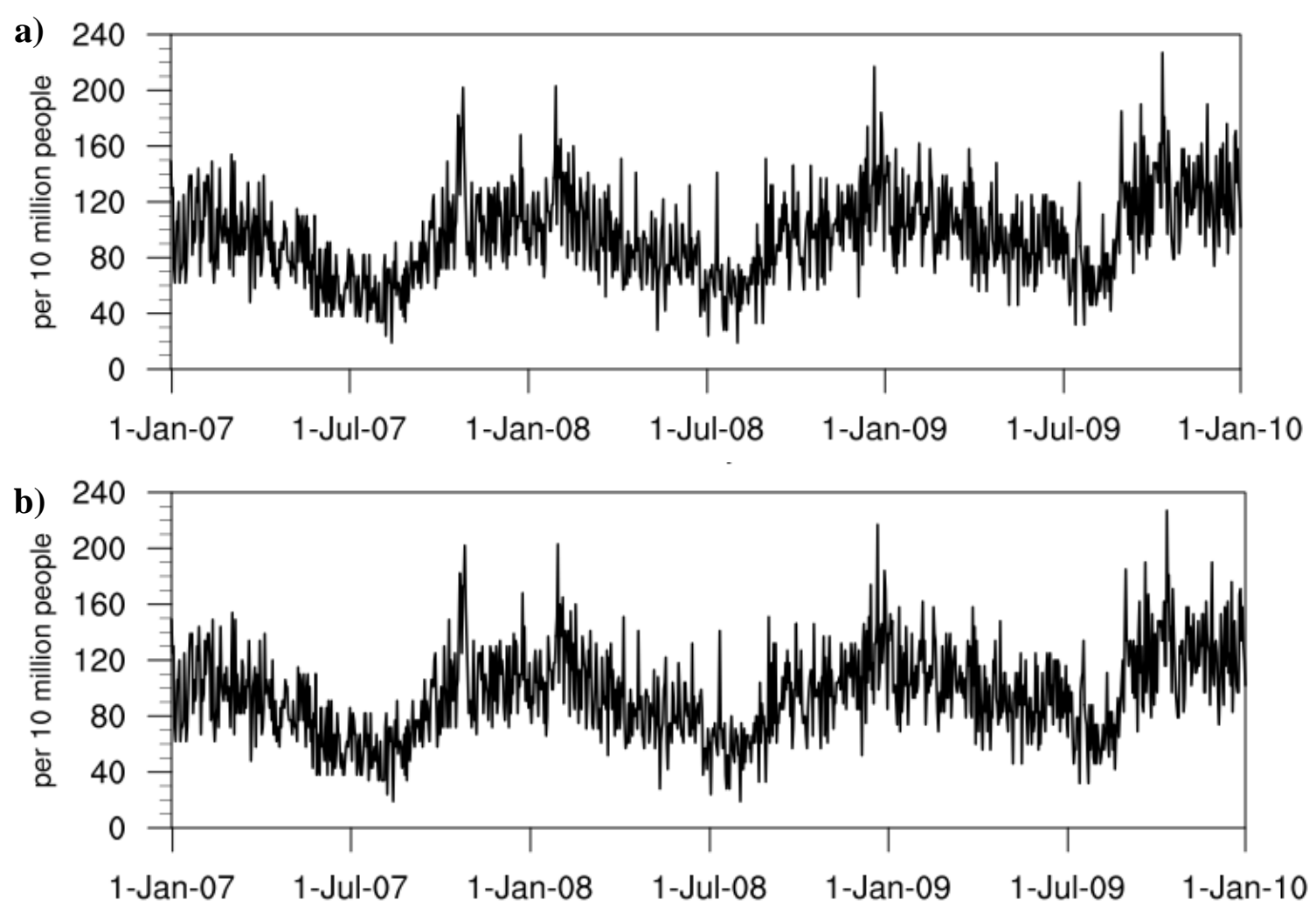

Fig. 5. Time Series of Asthma ED counts per ten million people for all hospitals in (a) Los Angeles County and (b) Riverside County during the years 2007-2009

Table 3. Average Asthma ED visits per ten million people by year

\begin{tabular}{|c|c|c|c|}
\hline & 2007 & 2008 & 2009 \\
\hline LOS ANGELES & 102 & 105 & 119 \\
\hline RIVERSIDE & 85 & 91 & 105 \\
\hline
\end{tabular}

Fig. 6 illustrates daily time series plots of county-level average surface $\mathrm{PM}_{2.5}$.

There is no clear seasonal trend for minimums. Short-term peaks are seen for maximums as opposed to minimums in both counties. Maximums occurred during the fall and winter seasons. Los Angeles and Riverside both had a maximum value on 23 October 2007 at 65

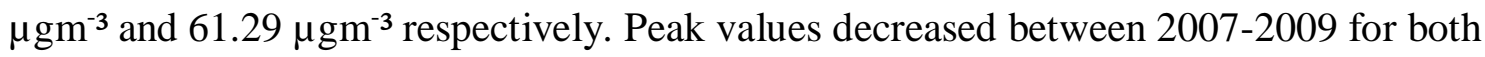


counties. Values for Los Angeles ranged between $0.11 \mu \mathrm{gm}^{-3}$ to $65 \mu \mathrm{gm}^{-3}$ with an average of $11.95 \mu \mathrm{gm}^{-3}$ for all three years. Values for Riverside ranged between $2.06 \mu \mathrm{gm}^{-3}$ to $61.29 \mu \mathrm{gm}^{-3}$ with an average of $12.57 \mu \mathrm{gm}^{-3}$ for all three years.
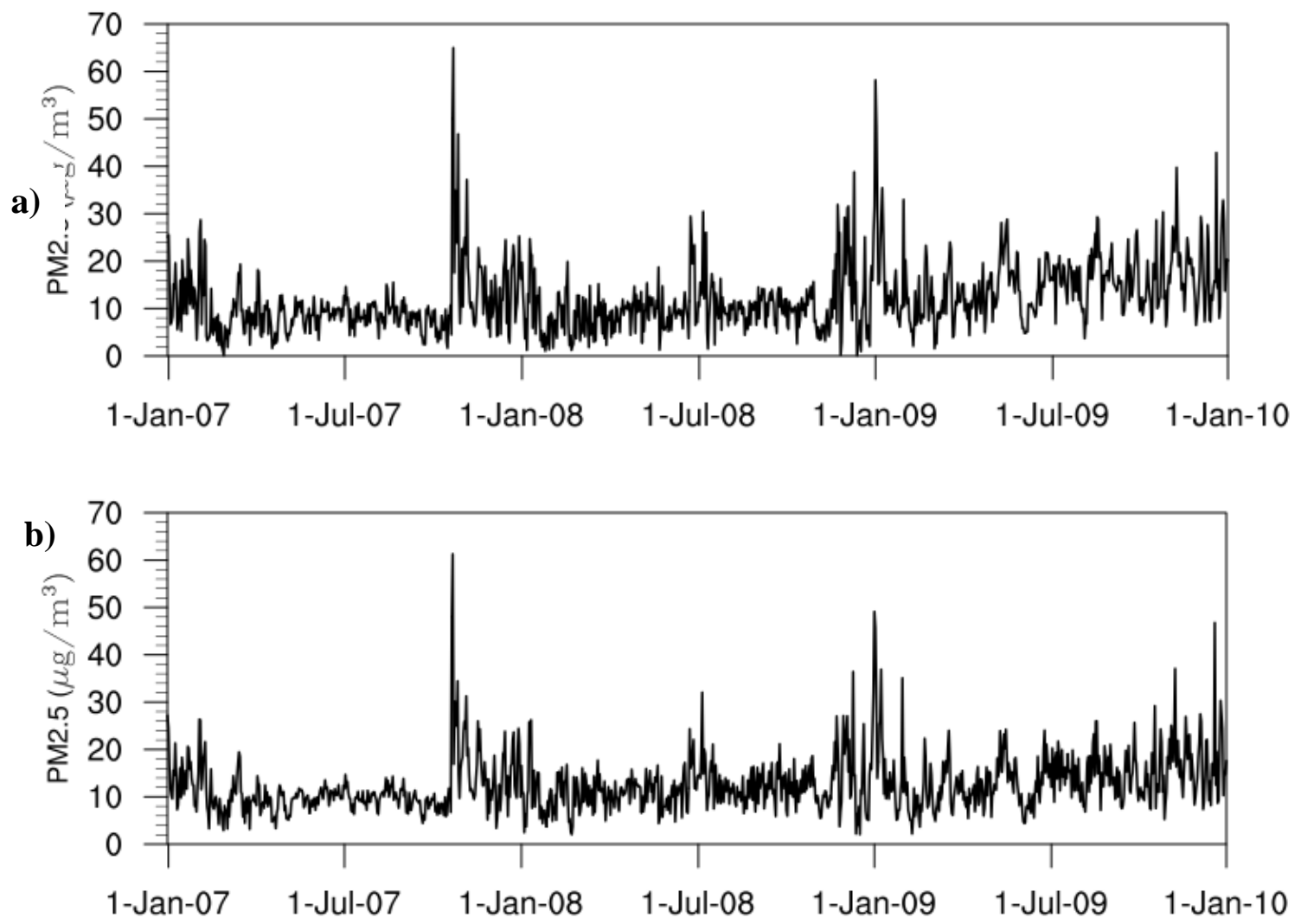

Fig. 6. Daily fine particulate matter $\left(\mathrm{PM}_{2.5}\right)\left(\mu \mathrm{g} / \mathrm{m}^{3}\right)$ for years 2007-2009 on CDC WONDER Online Database, released 2012, for (a) Los Angeles County and (b) Riverside County.

\subsection{Data correlations}

$\mathrm{NO}_{2}, \mathrm{CO}, \mathrm{PM}_{2.5}$, and inversion height were positively correlated with asthma for the entire 2007-2009 period and per individual year while $\mathrm{O}_{3}$, dew point, temperature, and wind speed were negatively correlated with asthma (Table 4). 
Table 4. Correlations for original dataset and modified dataset with difference between both datasets for (a) Los Angeles and (b) Riverside Counties 1-Jan-07 to 31-Dec-09.

\begin{tabular}{lcccccccc}
\hline $\begin{array}{l}\text { Los Angeles } \\
\text { 2007-2009 }\end{array}$ & $\mathrm{O} 3$ & $\mathrm{NO} 2$ & $\mathrm{CO}$ & $\mathrm{PM} 2.5$ & $\mathrm{Dew}$ Pt & Temp & WSF2 & Inv. H \\
\hline Asthma $(\mathrm{n}=1096)$ & $-0.449^{* *}$ & $0.196^{* *}$ & $0.326^{* *}$ & $0.180^{* *}$ & $-0.481^{* *}$ & $-0.544^{* *}$ & $-0.136^{* *}$ & $0.289^{* *}$ \\
Asthma+ $(\mathrm{n}=966)$ & $-0.502^{* * *}$ & $0.199^{* *}$ & $0.339^{* * *}$ & $0.143^{* *}$ & $-0.530^{* *}$ & $-0.611^{* *}$ & $-0.107^{* *}$ & $0.299^{* *}$ \\
\hline Difference & 0.053 & 0.003 & 0.013 & 0.037 & 0.048 & 0.067 & 0.029 & 0.010
\end{tabular}

\begin{tabular}{lcccccccc}
\hline $\begin{array}{l}\text { Riverside } \\
\text { 2007-2009 }\end{array}$ & $\mathrm{O} 3$ & $\mathrm{NO} 2$ & $\mathrm{CO}$ & $\mathrm{PM} 2.5$ & Dew Pt & Temp & WSF2 & Inv. H \\
\hline Asthma $(\mathrm{n}=1096)$ & $-0.441^{* *}$ & $0.128^{* * *}$ & $0.192^{* *}$ & $0.188^{* *}$ & $-0.366^{* *}$ & $-0.441^{* *}$ & $-0.150^{* *}$ & $0.256^{* *}$ \\
Asthma+ $(\mathrm{n}=1045)$ & $-0.464^{* *}$ & $0.124 * *$ & $0.185^{* *}$ & $0.142^{* *}$ & $-0.375^{* *}$ & $-0.480^{* *}$ & $-0.151^{* * *}$ & $0.269^{* *}$ \\
\hline $\begin{array}{l}\text { Difference } \\
* P \text {-value }<0.05\end{array}$ & $\begin{array}{l}* * 023 \\
P \text {-value }<0.01\end{array}$ & 0.004 & 0.007 & 0.047 & 0.010 & 0.039 & 0.001 & 0.012 \\
\end{tabular}

Analyzing the differences between both datasets (Table 4), we found that all correlations increased from the original to modified version with the exception of $\mathrm{PM}_{2.5}$ and wind speed in Los Angeles. Riverside saw increases in correlations for $\mathrm{O}_{3}$, dew point, temperature, wind speed, and inversion height and decreases in $\mathrm{NO}_{2}, \mathrm{CO}$, and $\mathrm{PM}_{2.5}$. Differences ranged between 0.001 and 0.067 .

Datasets were broken down by year as shown in Table 5. Differences ranged between 0.001 and 0.144 with $\mathrm{PM}_{2.5}$ having the highest difference, approximately 2.5 times more than the second highest value in both Los Angeles and Riverside. All variables followed the same positive or negative correlation pattern as per Table 4. 
Table 5. Correlations for original dataset and modified dataset with difference between both datasets for (a) Los Angeles and (b) Riverside Counties 1-Jan-07 to 31-Dec-07.

\begin{tabular}{lrrrrrrrr}
\hline Los Angeles-2007 & $\mathrm{O} 3$ & $\mathrm{NO} 2$ & $\mathrm{CO}$ & $\mathrm{PM} 2.5$ & Dew Pt & Temp & WSF2 & Inv. H \\
\hline Asthma $(\mathrm{n}=365)$ & $-0.547^{* *}$ & $0.268^{* *}$ & $0.398^{* *}$ & $0.290^{* *}$ & $-0.541^{* *}$ & $-0.610^{* *}$ & $-0.175^{* *}$ & $0.369^{* *}$ \\
Asthma+ $(\mathrm{n}=327)$ & $-0.575^{* *}$ & $0.231^{* *}$ & $0.374^{* *}$ & $0.147^{* *}$ & $-0.543^{* *}$ & $-0.668^{* *}$ & $-0.136^{*}$ & $0.368^{* *}$ \\
\hline Difference & 0.028 & 0.037 & 0.024 & 0.143 & 0.001 & 0.058 & 0.039 & 0.001
\end{tabular}

\begin{tabular}{lcccccccc}
\hline Riverside-2007 & $\mathrm{O} 3$ & $\mathrm{NO} 2$ & $\mathrm{CO}$ & $\mathrm{PM} 2.5$ & Dew Pt & Temp & WSF2 & Inv. H \\
\hline Asthma $(\mathrm{n}=365)$ & $-0.490^{* *}$ & $0.174 * *$ & $0.310^{* *}$ & $0.376^{* *}$ & $-0.480^{* *}$ & $-0.504^{* *}$ & $-0.111^{*}$ & $0.315^{* *}$ \\
Asthma+ $(\mathrm{n}=350)$ & $-0.501 * *$ & $0.168 * *$ & $0.316^{* *}$ & $0.232^{* *}$ & $-0.481^{* *}$ & $-0.562^{* *}$ & -0.102 & $0.332^{* *}$ \\
\hline $\begin{array}{l}\text { Difference } \\
* P \text {-value }<0.05\end{array}$ & $\begin{array}{l}0.011 \\
\text { P-value }<0.01\end{array}$ & 0.005 & 0.006 & 0.144 & 0.001 & 0.058 & 0.009 & 0.017 \\
\end{tabular}

Fall of 2007 (Table 6), had the highest positive correlation for $\mathrm{PM}_{2.5}$ in the original dataset for both Los Angeles and Riverside counties compared to all other variables. $\mathrm{PM}_{2.5}$ also had the greatest differentiation between the original and modified version. Delta values ranged between 0.021 and 0.471 with $\mathrm{PM}_{2.5}$ being 3.5 times more than the second highest difference in Riverside and 1.5 times more in Los Angeles. A two-tail Pearson correlation significance test was applied for Fall of 2007 values. $\mathrm{PM}_{2.5}$, dew point, temperature, wind speed, and inversion height were statistically significant with a $P$-value less than 0.01 in the original set for Los Angeles while only significant for temperature in the modified dataset. For Riverside's original dataset, at the same $P$-value, $\mathrm{O}_{3}, \mathrm{PM}_{2.5}$, dew point, and temperature were statistically significant while for the modified dataset ozone and temperature were. 
Table 6. Correlations for original dataset and modified dataset with difference between both datasets for (a) Los Angeles and (b) Riverside Counties 1-Sep-07 to 30-Nov-07.

\begin{tabular}{|c|c|c|c|c|c|c|c|c|}
\hline $\begin{array}{l}\text { Los Angeles- } \\
\text { Fall } 07 \\
\end{array}$ & $\mathrm{O} 3$ & $\mathrm{NO} 2$ & $\mathrm{CO}$ & PM2.5 & Dew Pt & Temp & WSF2 & Inv. $\mathrm{H}$ \\
\hline Asthma $\quad(n=91)$ & -0.200 & 0.124 & 0.206 & $0.372 * *$ & $-0.490 * *$ & $-0.354 * *$ & $-0.263 * *$ & $0.306 * *$ \\
\hline Asthma+ $(n=67)$ & -0.088 & -0.026 & 0.019 & -0.045 & -0.211 & $-0.415^{* *}$ & -0.123 & 0.171 \\
\hline Difference & 0.112 & 0.150 & 0.187 & 0.417 & 0.279 & 0.061 & 0.140 & 0.135 \\
\hline $\begin{array}{l}\text { Riverside- } \\
\text { Fall } 07\end{array}$ & $\mathrm{O} 3$ & $\mathrm{NO} 2$ & $\mathrm{CO}$ & PM2.5 & Dew Pt & Temp & WSF2 & Inv. $\mathrm{H}$ \\
\hline Asthma $\quad(n=91)$ & $-0.271 * *$ & 0.024 & 0.176 & $0.481 * *$ & $-0.357 * *$ & $-0.285^{* *}$ & -0.166 & $0.212^{*}$ \\
\hline Asthma+ $(n=76)$ & $-0.307 * *$ & 0.004 & 0.144 & 0.010 & -0.211 & $-0.414 * *$ & $-0.238^{*}$ & 0.128 \\
\hline Difference & 0.036 & 0.021 & 0.033 & 0.471 & 0.146 & 0.129 & 0.072 & 0.084 \\
\hline
\end{tabular}

It is important to note that the modified dataset that excludes fire events do not take into account fires whose plume might have dispersed into the county. Wind direction was considered but excluded from the study.

Fig. 7 and Fig. 8 are graphical representations of the correlations between $\mathrm{PM}_{2.5}$ and asthma for Los Angeles and Riverside during fall of 2007. Set (a) original dataset and set (c) fires-only dataset had a $P$-value $<0.01$ making them statistically significant while set (b) modified dataset was not. Set (c) had a significant positive correlation at 0.571 for Los Angeles and 0.687 for Riverside. 


\section{LOS ANGELES FALL 2007 \\ ORIGINAL DATASET**}

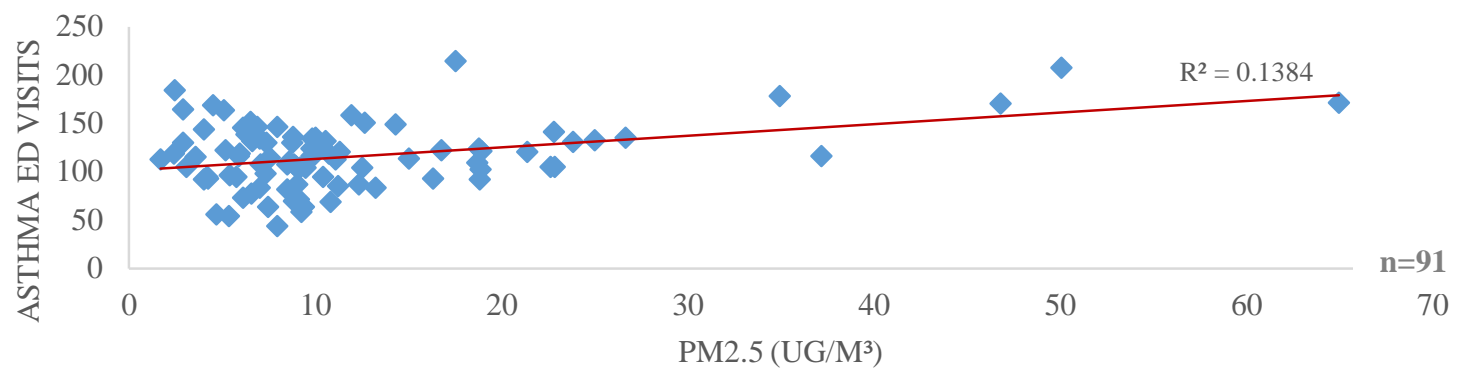

LOS ANGELES FALL 2007

MODIFIED DATASET

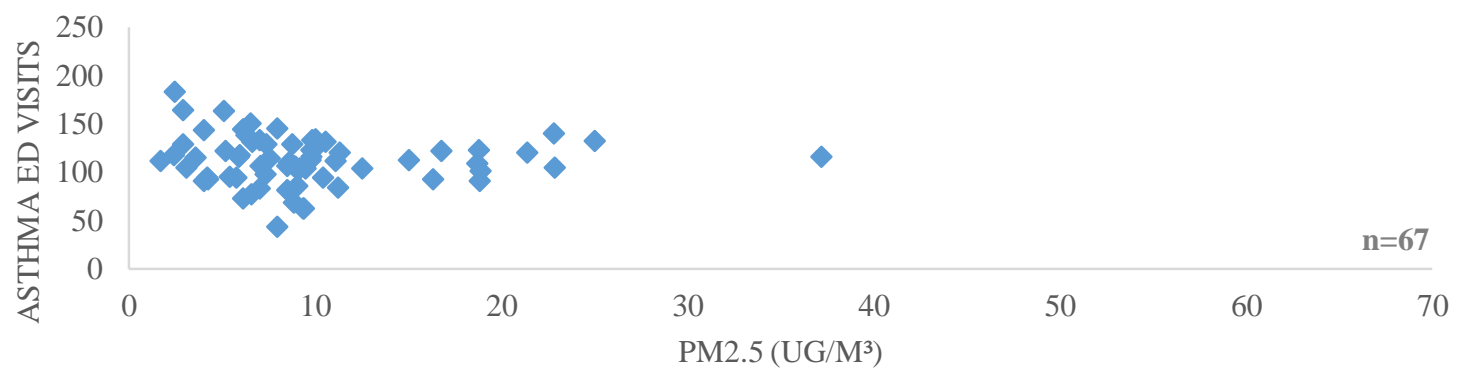

LOS ANGELES FALL 2007

FIRES ONLY**

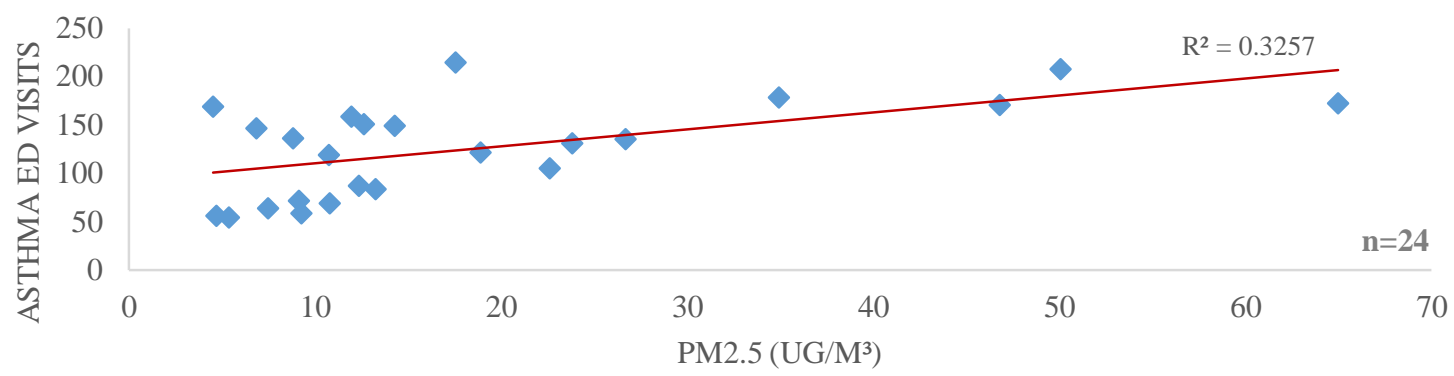

** P-value $<0.01$

Fig. 7. Scatter diagrams for daily average $\mathrm{PM}_{2.5}$ and Asthma ED Visits from 1-Sep-07 to 31-Nov-07 in Los Angeles County for (a) original dataset (b) modified dataset and (c) dataset during fire events. The regression line is included when correlation data is statistically significant. 
RIVERSIDE FALL 2007

ORIGINAL DATASET**

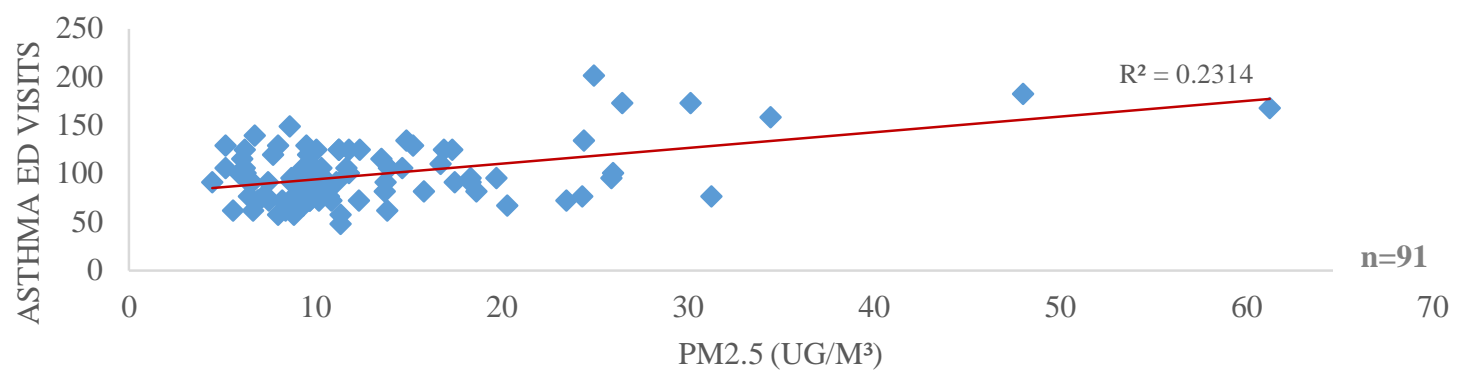

RIVERSIDE FALL 2007

MODIFIED DATASET

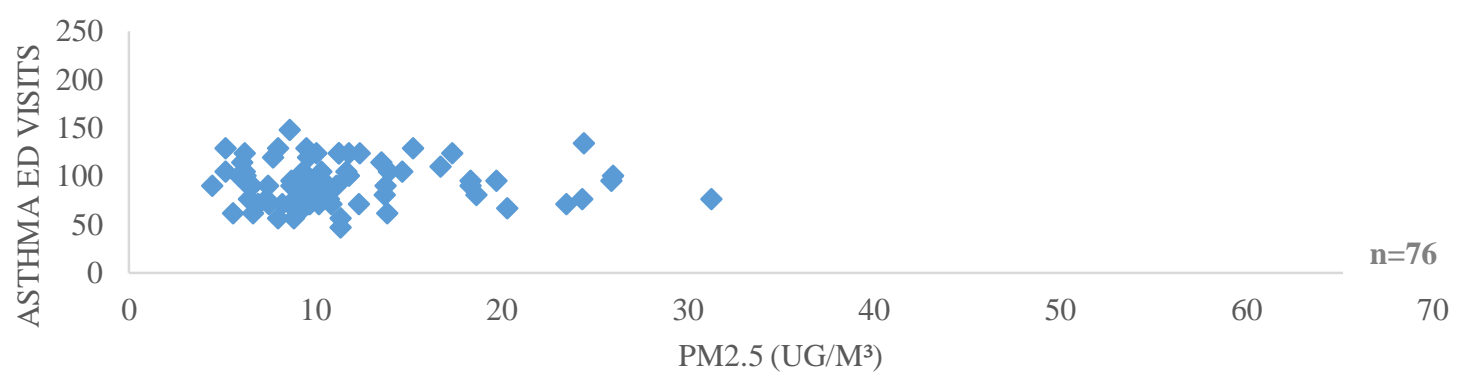

RIVERSIDE FALL 2007

FIRES ONLY**

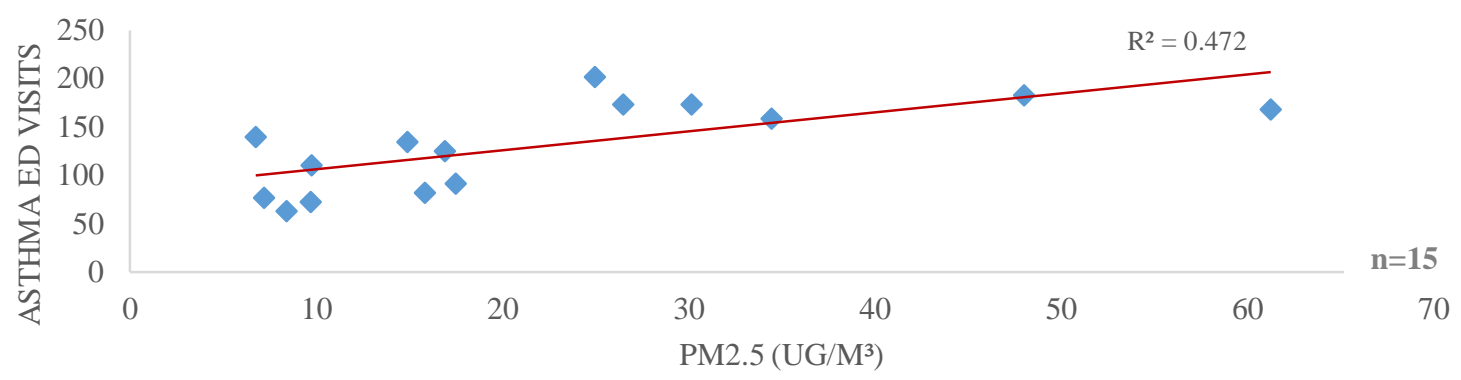

** P-value $<0.01$

Fig. 8. Scatter diagrams for daily average $\mathrm{PM}_{2.5}$ and Asthma ED Visits from 1-Sep-07 to 31-Nov-2007 in Riverside County for (a) original dataset (b) modified dataset and (c) dataset during fire events. The regression line is included when correlation data is statistically significant. 


\subsection{Ground Observations for $P M_{2.5}$}

A time series of $\mathrm{PM}_{2.5}$ was produced to analyze particulates during October 2007.

Ground observations (Fig. 9), show higher than average values of $\mathrm{PM}_{2.5}$ between October 22 and October 28. The average $\mathrm{PM}_{2.5}$ was $13.96 \mu \mathrm{gm}^{-3}$ for Los Angeles and $14.79 \mu \mathrm{gm}^{-3}$ for Riverside. The highest amount of $\mathrm{PM}_{2.5}$ occurred on October $23^{\text {rd }}$ at a value of 64 $\mu \mathrm{gm}^{-3}$ for Los Angeles and $61.29 \mu \mathrm{gm}^{-3}$ for Riverside, both approximately 1.8 times higher than the National Ambient Air Quality Standard (NAAQS) of $35 \mu \mathrm{gm}^{-3}$ per 24hour period. Most significant increase was noticed on October $22^{\text {nd }}$, approximately 4 times higher than average levels.
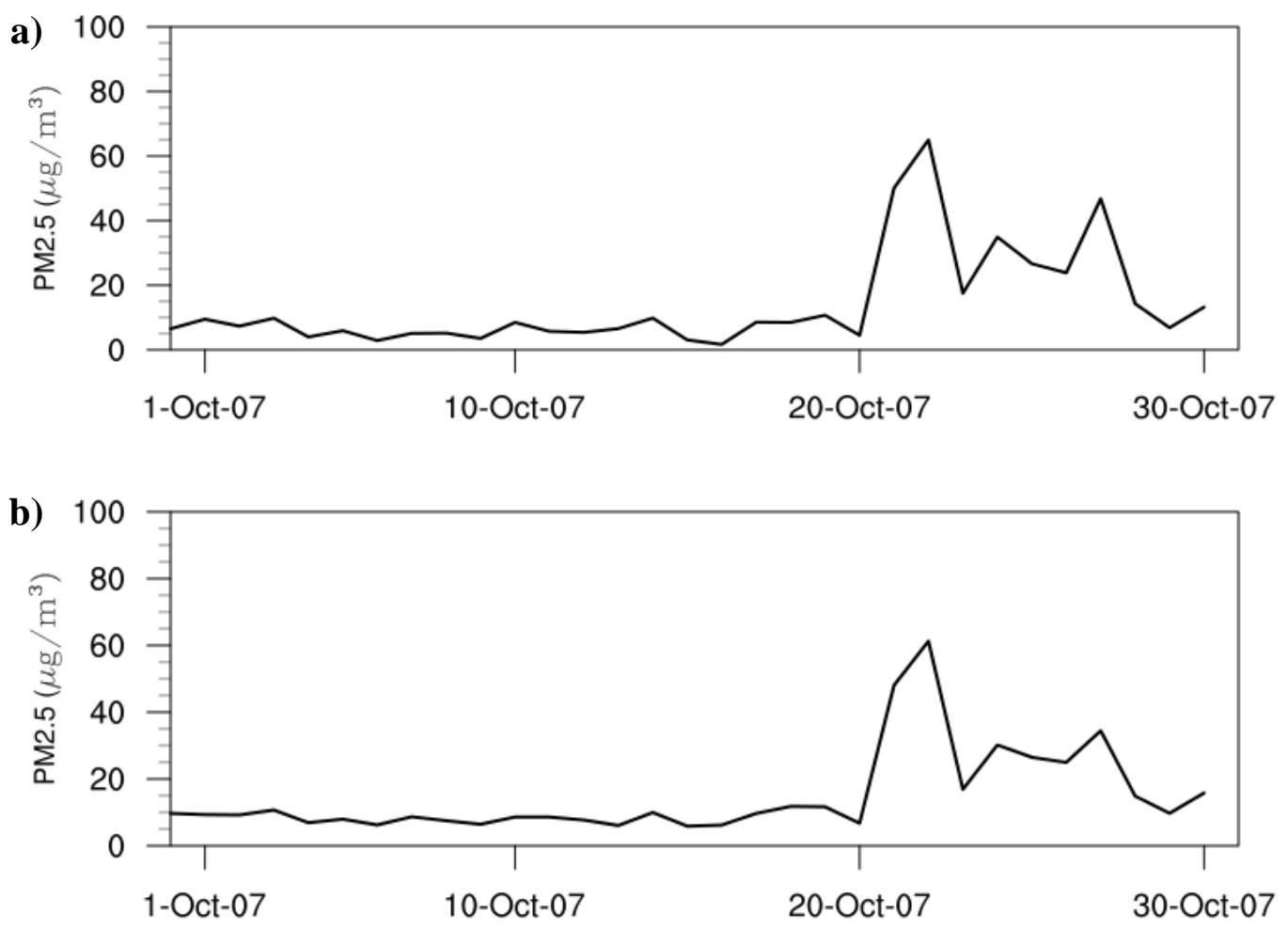

Fig. 9. Daily average fine particulate matter $\left(\mathrm{PM}_{2.5}\right)\left(\mu \mathrm{gm}^{-3}\right)$ from 1-Oct-07 to 31-Oct-07 on CDC WONDER Online Database, released 2012, for (a) Los Angeles County and (b) Riverside County. 


\subsection{Meteorological Conditions}

The outbreak of fires and its containment are directly impacted by existing weather conditions. Fire weather is a term used to describe the meteorological conditions that are routinely observed during wildfire events (Clements 2011). Radiosonde data indicated a weakly stable atmosphere with a shallow inversion from 22 to 27 October. A strong inversion was evident on October $23^{\text {rd }}$ (Fig. 10).

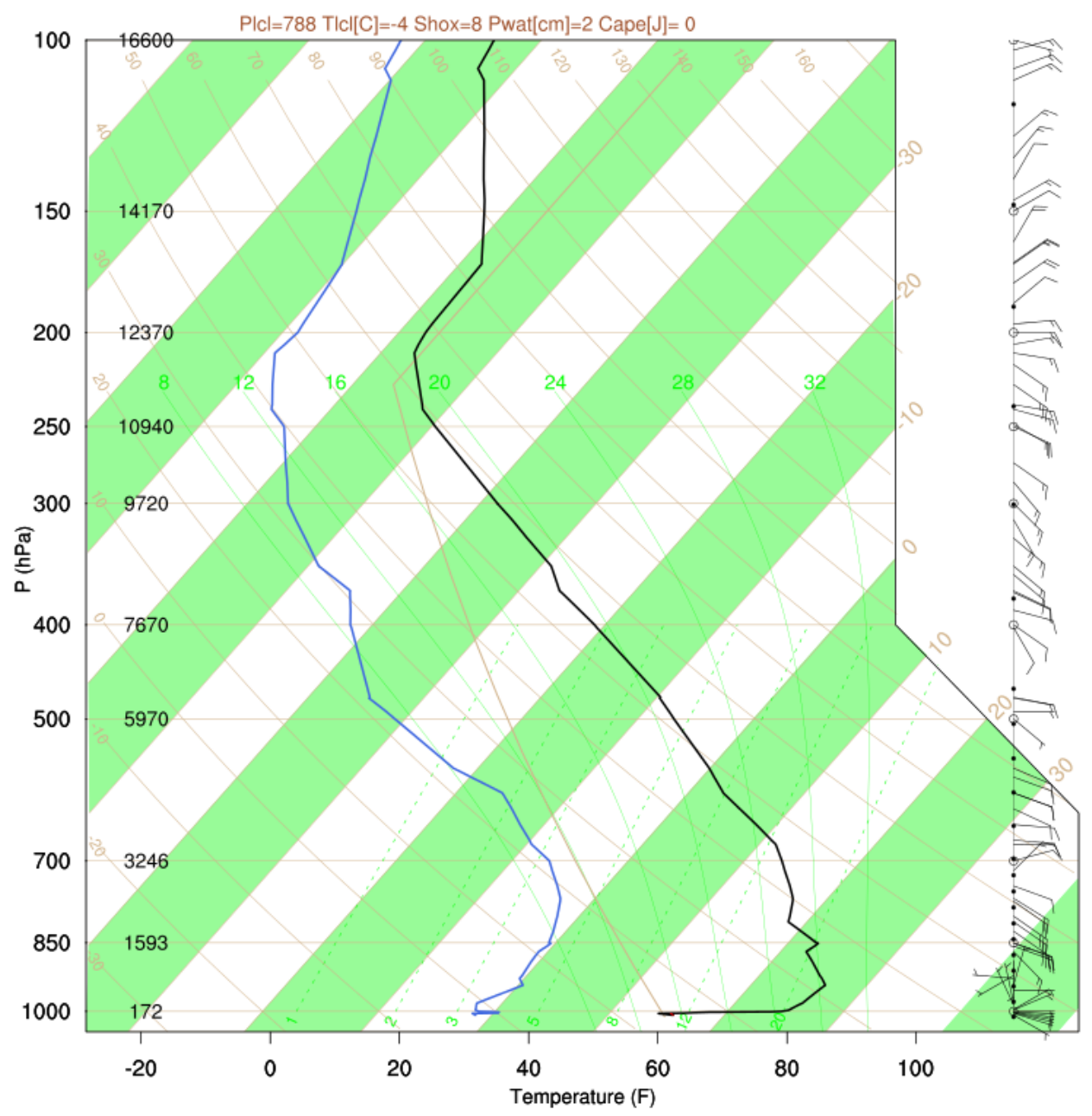

Fig. 10. Vertical temperature profile at Vandenberg Air Force Base 1200 UTC 23 October 2007. 
A subsidence inversion creates a stagnant atmosphere and can lead to an accumulation of pollutants at or near the surface, such was the case for our study period. In addition, winds were offshore from the surface to the 100-millibar level with slight veering (Fig. 10), an indication of warm advection in the upper atmosphere. Eventually, a shift in winds and the eastward movement of the high pressure system eroded the inversion.

A dominant ridge at the 500-millibar level (Fig. 11a), indicated a warm air mass over the region. At this same level a high pressure system was centered over the Sierra Nevada and western Nevada. At the surface (Fig. 11b), a high pressure system was centered over the border of Nevada, Utah, Idaho, and Colorado. High pressure at the surface and aloft generates northeasterly sinking air and offshore winds in the southeast quadrant of the high pressure system. By October $25^{\text {th }}$ (Fig. 13a), the high pressure system at the 500-millibar level moved eastward and weakened.

In addition, a strong pressure gradient at the surface was located over Southern California (Fig. 11b), due to a low pressure system off the coast of Baja California. A strong pressure gradient produces high winds. The pressure gradient weakened (i.e. isobars are more widespread) by October $24^{\text {th }}$ (Fig. 12a,b), and further on October 25th (Fig. 13b), reducing the speed of the winds. By October $26^{\text {th }}$ (Fig. 14a,b), the high pressure system passed the region at the surface and aloft. A low pressure system is now visible at the surface with the return of onshore winds. 
a)

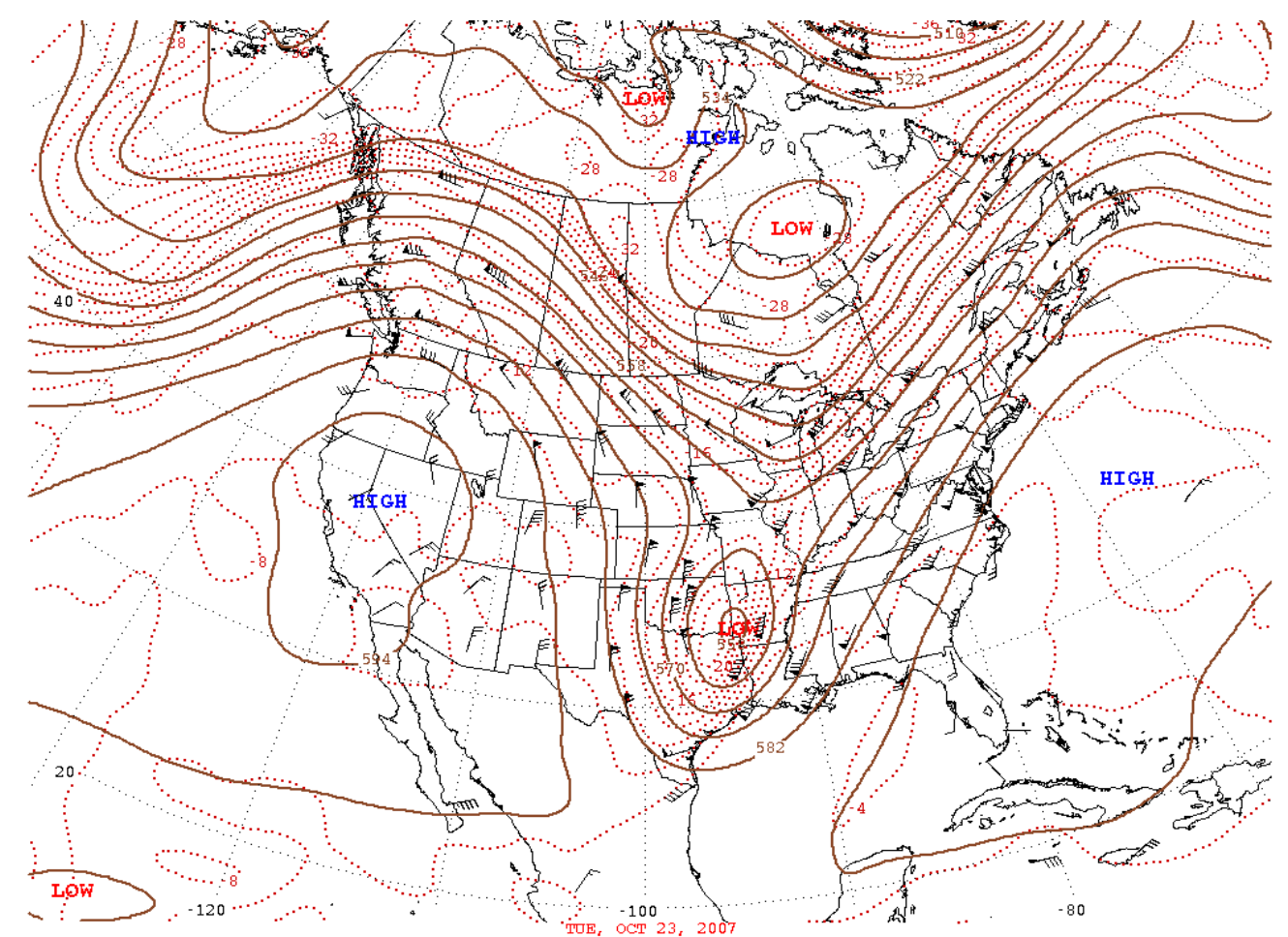

b)

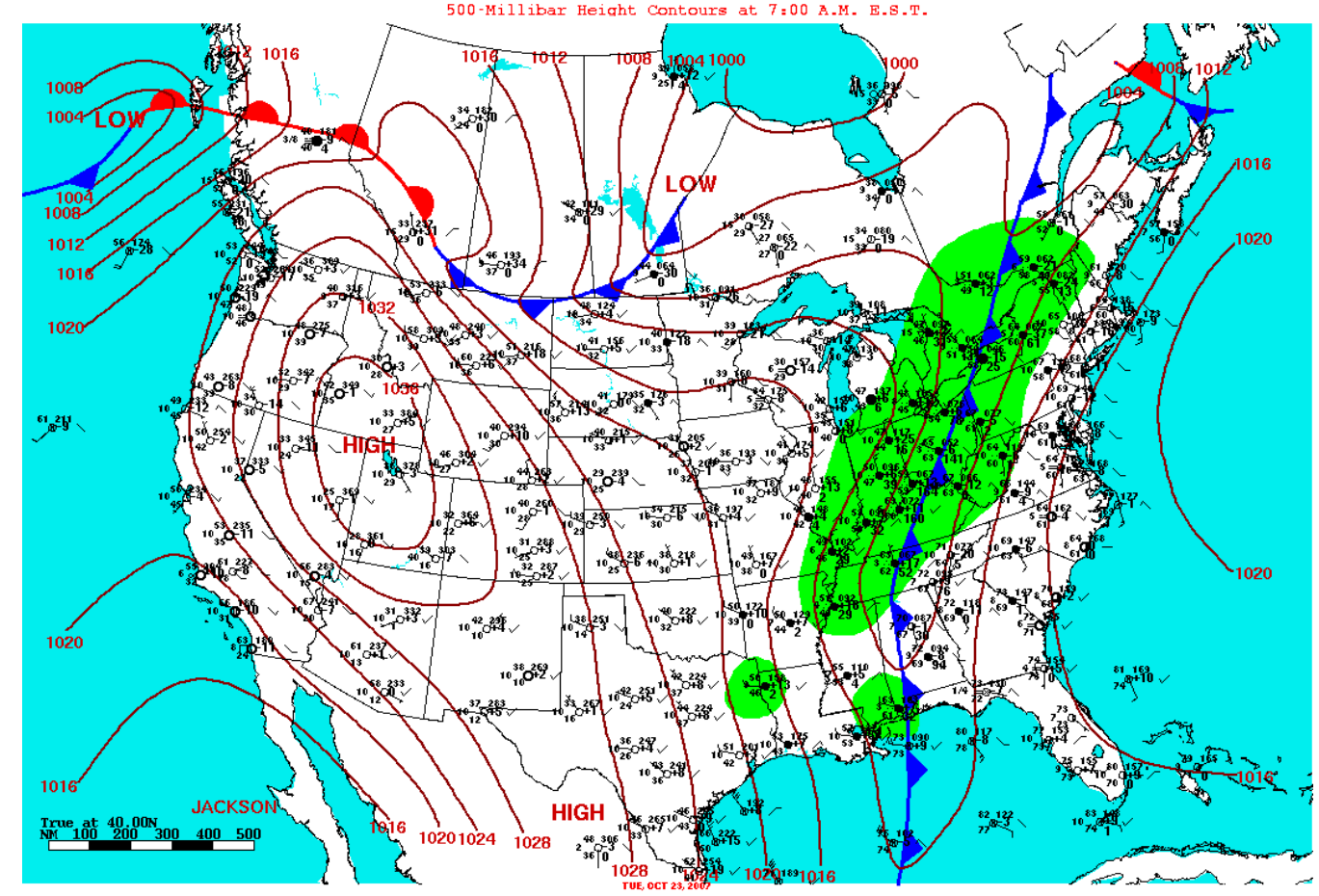

Surface Weather Map and Station Heather at 7:00 A.M. E.S.T.

Fig. 11. National Centers for Environmental Prediction, Weather Prediction Center daily weather map at 23 October 20071200 UTC for (a) 500-millibar height observations and (b) surface analysis 
a)

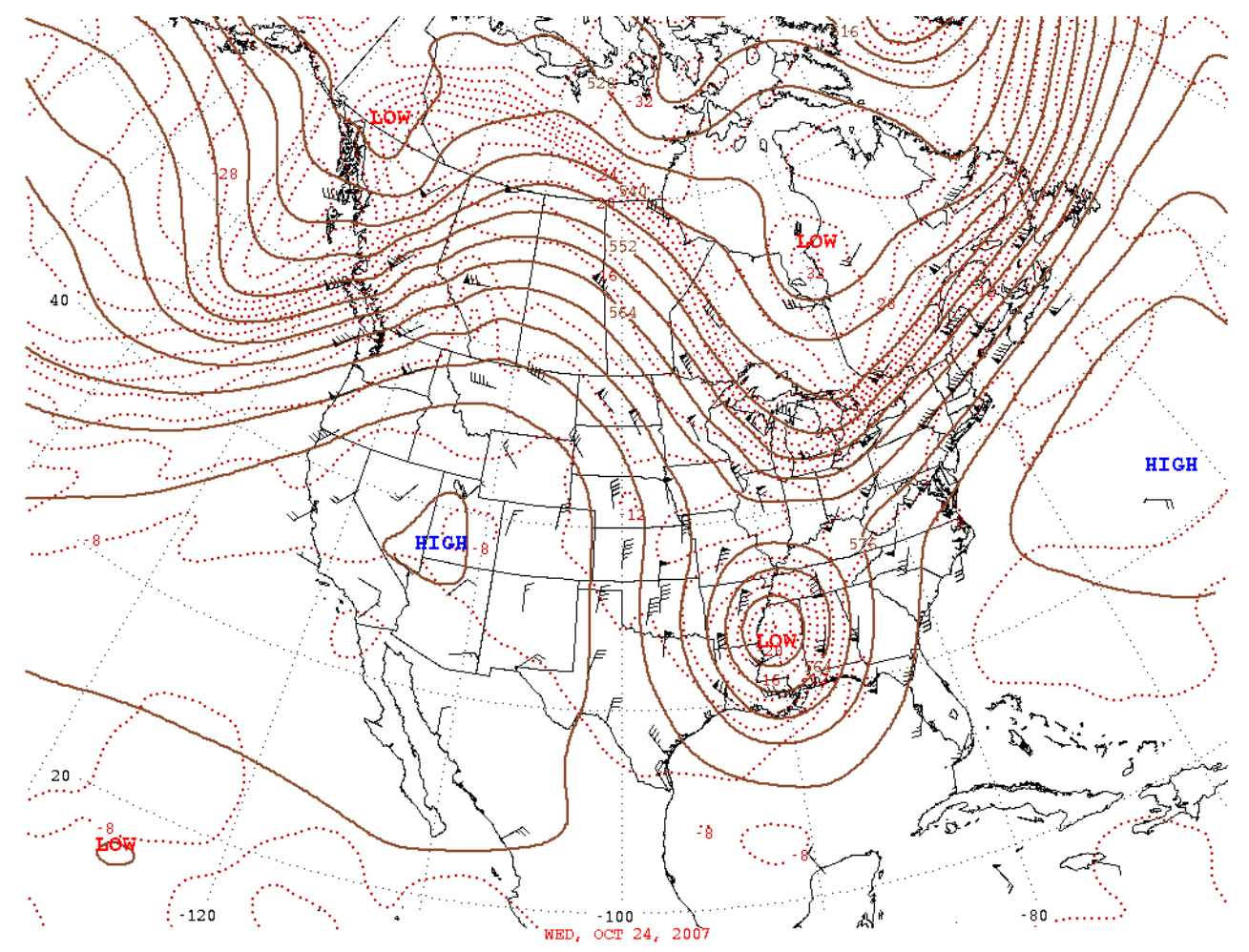

b)

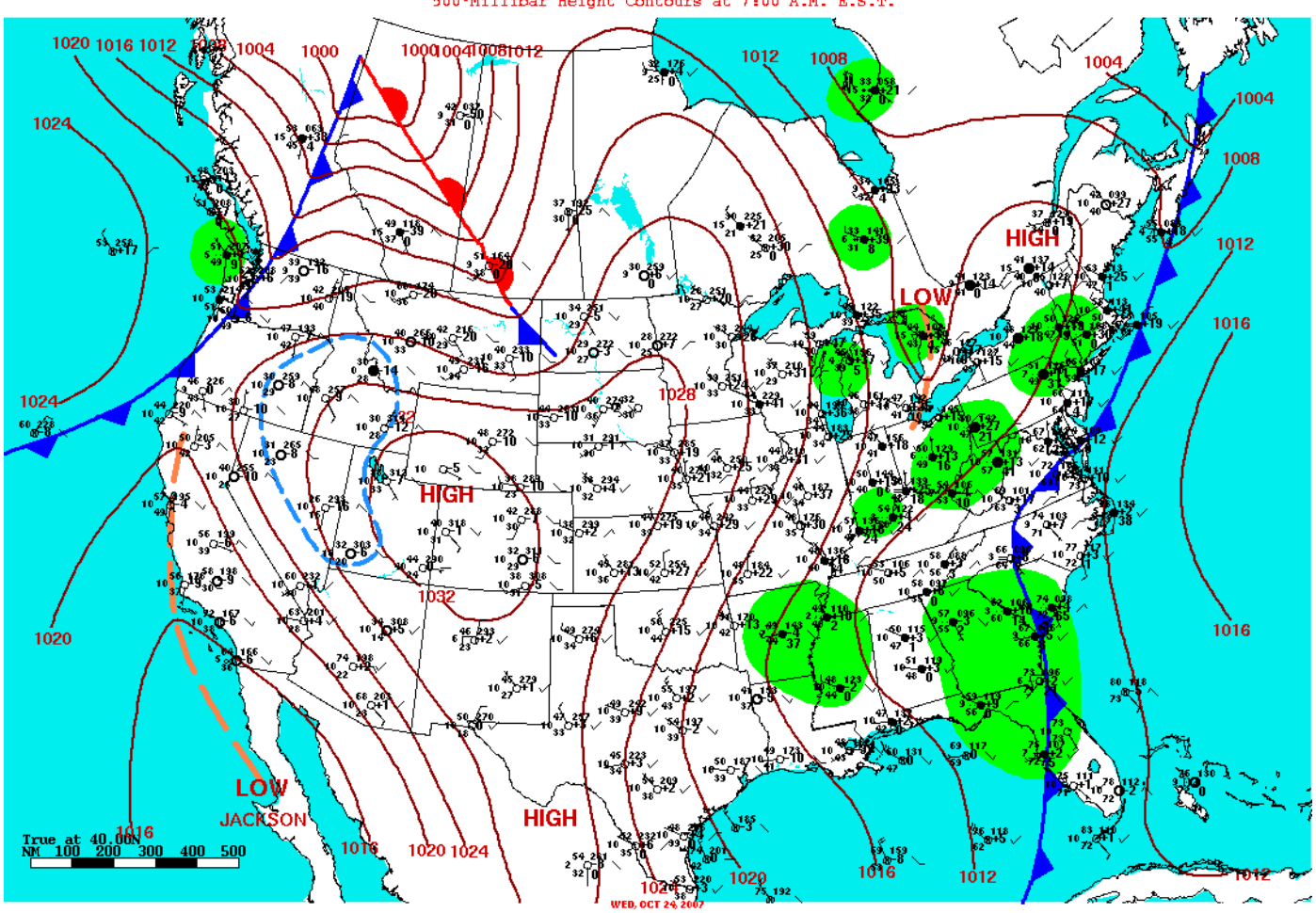

Surface Weather Map and station Weather at 7:00 A.M. E.S.T.

Fig. 12. Continued 24 October 20071200 UTC. 
a)

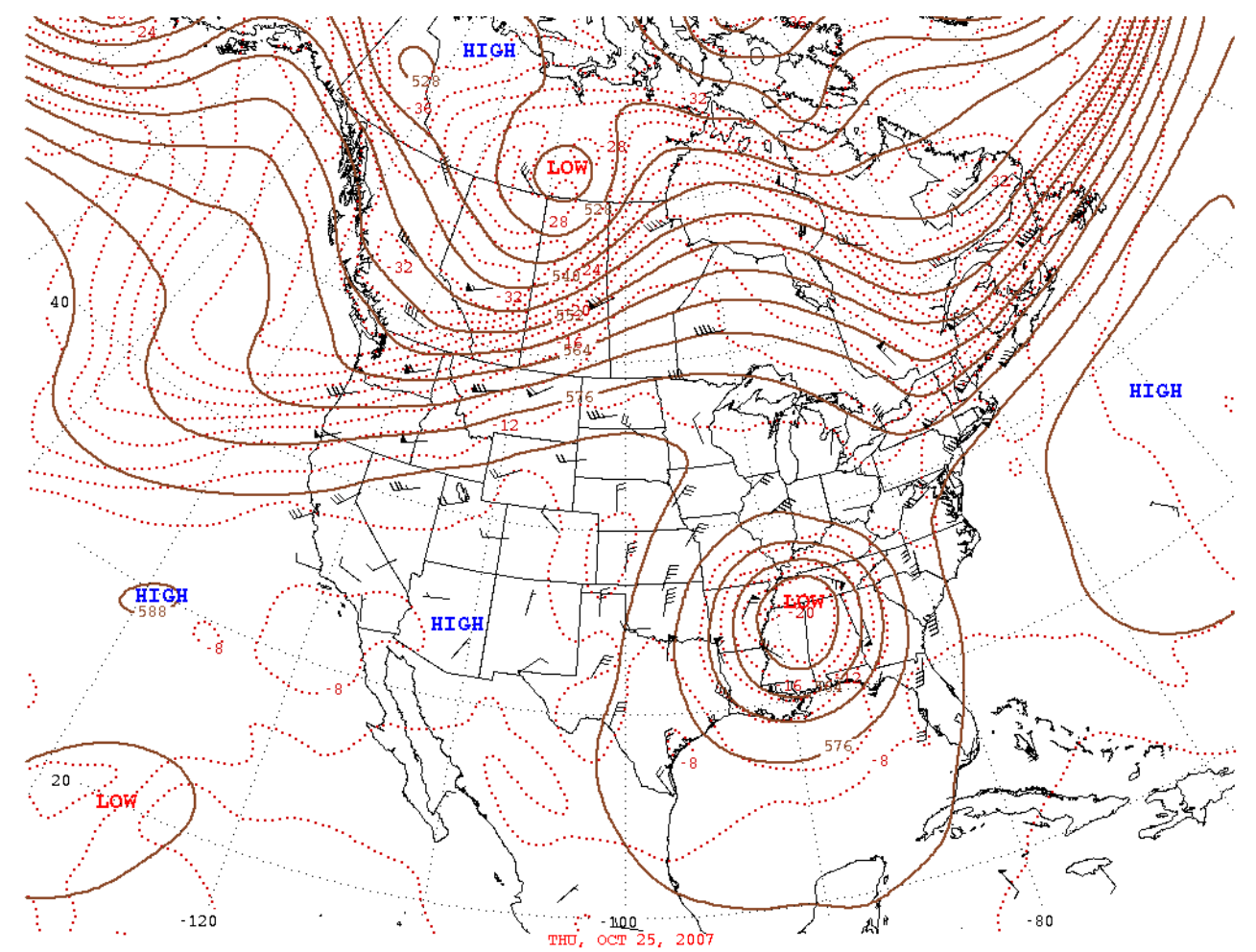

b)

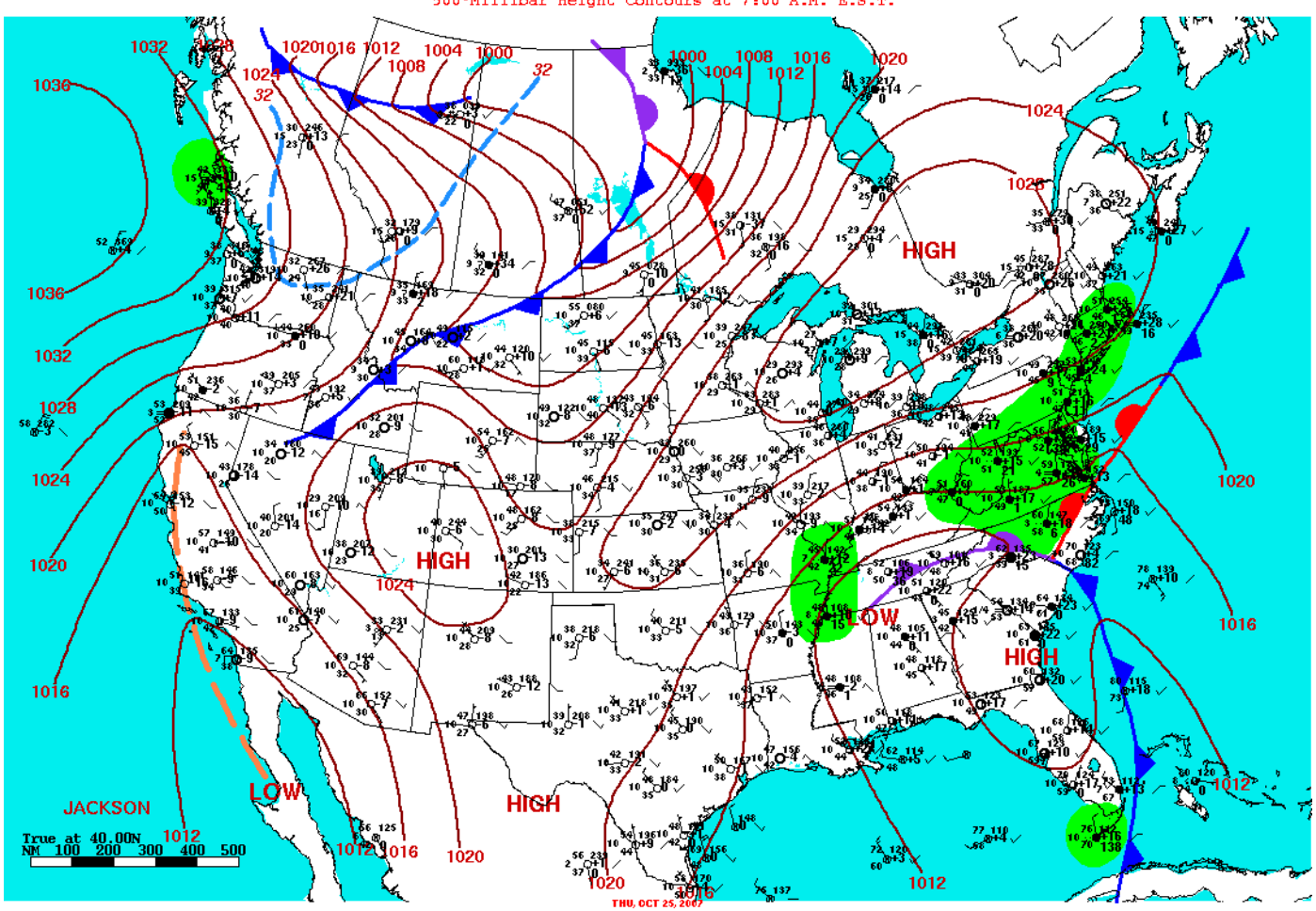

Surface Weather Map and station Weather at 7:00 A.M. E.S.T.

Fig. 13. Continued 25 October 20071200 UTC. 
a)

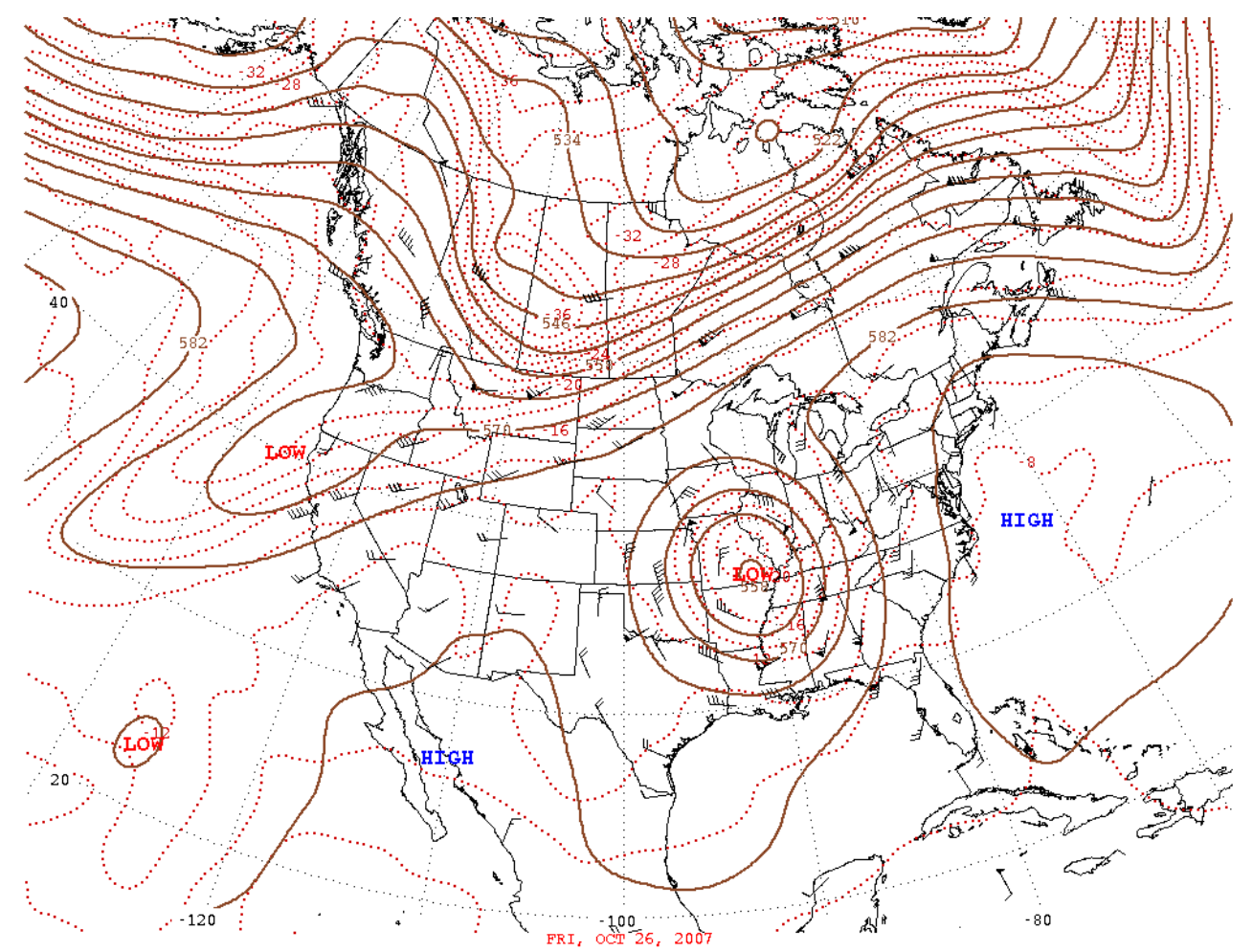

b)

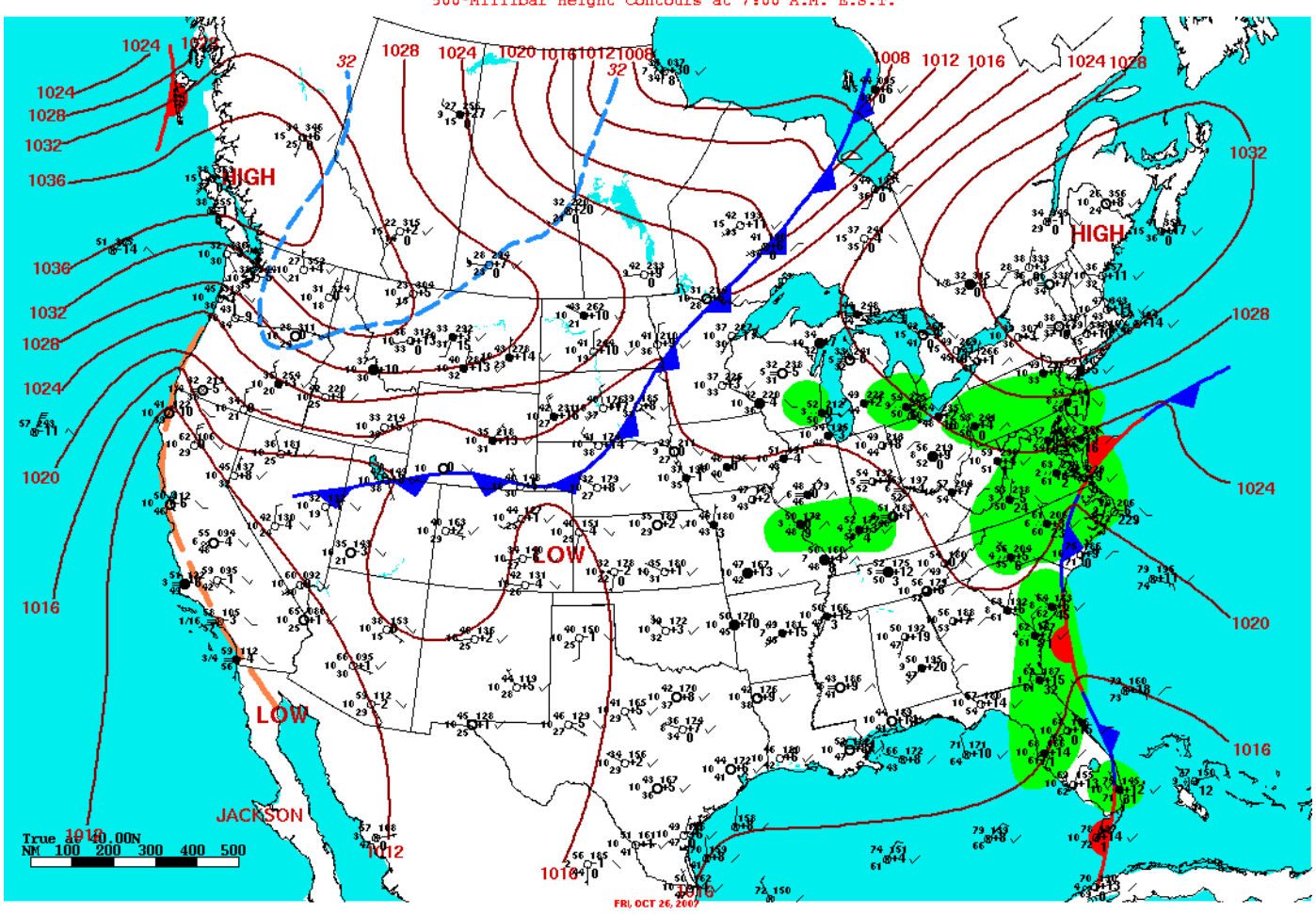

Surface Weather Map and station Weather at 7:00 A.M. E.S.T.

Fig. 14. Continued 26 October 20071200 UTC. 
A common and important factor affecting fire behavior are winds produced by mountainous terrain known as foehn winds. Foehn winds are warm dry winds that develop on the leeside of a mountain range and are associated with extreme fire behavior because of their near-surface high wind speeds, warm temperatures, and low relative humidity (Durran 1990, Whiteman 2000). The most prominent foehn wind related to extreme fire cases in the Southern California region are the Santa Ana winds. Santa Ana winds develop as a result of a high pressure over the Great Basin and development of a surface low off the Southern California coast, with an upper level trough to the east and a ridge in the eastern North Pacific (Barry 2008). Surface Santa Ana winds are due to two factors according to Hughes and Hall (2009). The first is strong mid-tropospheric winds that touch the mountaintops in a stable environment causing midlevel momentum from gravity waves transferring to the surface and thus strong lee-side surface winds. The second factor is cold air that is trapped in the Great Basin by topography. A pressure gradient forms due to the hydrostatic desert and ocean air interaction. This results in a negatively buoyant gravity current to flow through mountain gaps, accelerating the air as it is channeled through the passes and canyons. During the October 2007 wildfire event, Santa Ana winds were considered a factor in the outbreak ("California Fire Siege 2007: An Overview", 2008).

Between 22 and 25 October Los Angeles had temperatures above $80^{\circ} \mathrm{F}$ and dew points at its lowest during the same period (Fig. 15a), plunging to $39^{\circ} \mathrm{F}$ on October $22^{\text {nd }}$. Riverside (Fig. 15b), had temperatures above $80^{\circ} \mathrm{F}$ between 23 and 29 October and its minimum dew point on October $22^{\text {nd }}$ at $16^{\circ} \mathrm{F}$. Dew point, a measurement of water vapor 
in the air, indicates how dry the atmosphere is. Riverside County appears to be warmer and dryer than Los Angeles County.
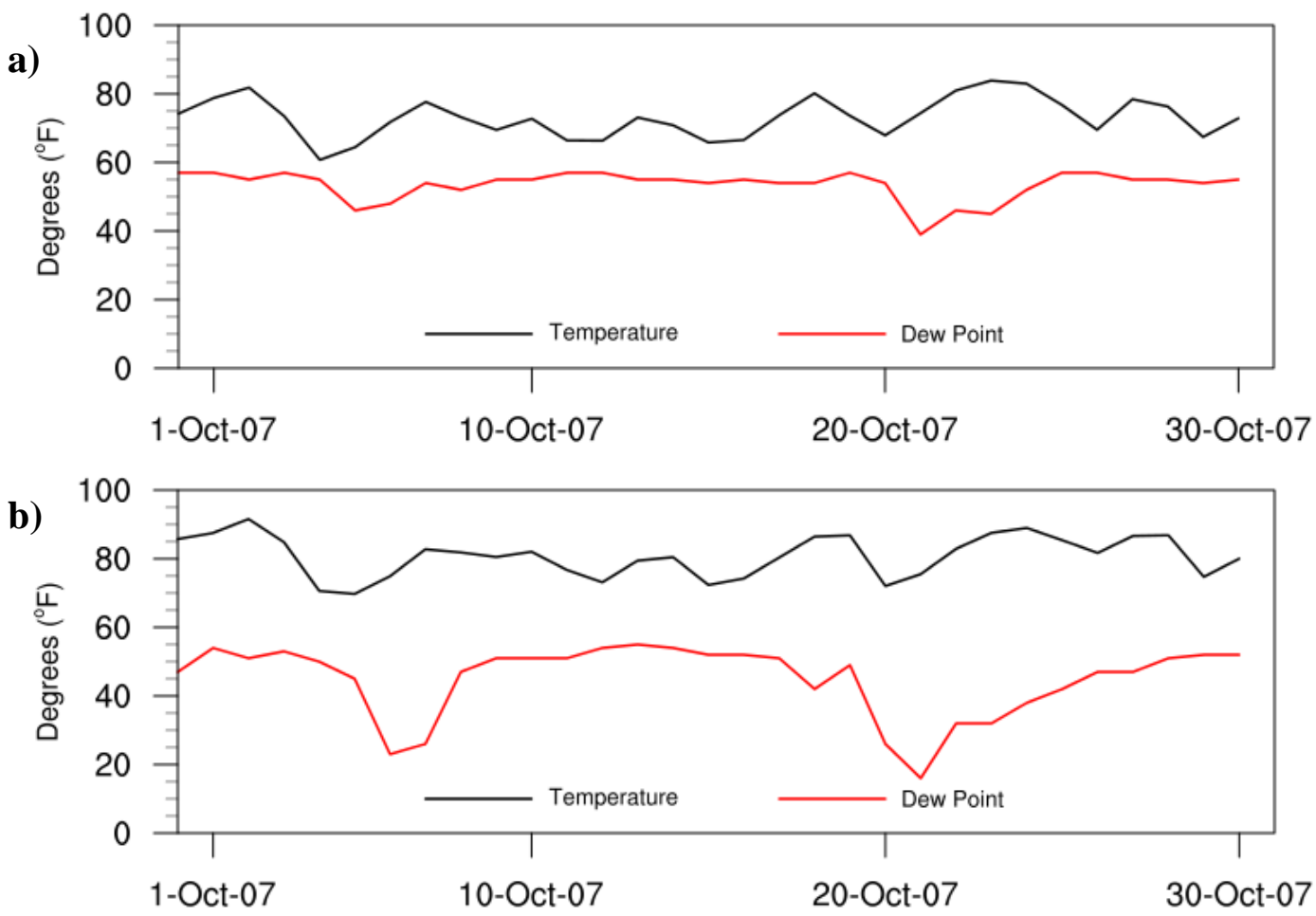

Fig. 15. Surface maximum temperature and dew point for (a) Los Angeles and (b) Riverside from 1-Oct-07 to 31-Oct-07.

The existence of Santa Ana winds dried out the surface further. Hot, dry winds lead to a drop in humidity values and under these conditions fires burn at a higher rate. By October $25^{\text {th }}$ (Fig. 13), onshore winds advected moisture into the area and subsequently increased dew point values.

Fig. 16 through 18 show surface wind vectors along with terrain elevations. On October $20^{\text {th }}$ (Fig. 16), winds were northwesterly through the Grapevine Pass (Fig. 4), at speeds between 12 and $16 \mathrm{~ms}^{-1}$. A diversion of winds around the Angeles National Forest and Mt. San Antonio was evident (Fig. 4), spilling into the Los Angeles basin. There is 
mild channeling of southerly winds through the Cajon Pass (Fig. 4) at speeds between 2 and $4 \mathrm{~ms}^{-1}$. An onshore flow in the Los Angeles basin diverted around the Santa Ana Mountains at wind speeds between 2 and $6 \mathrm{~ms}^{-1}$. Further inland at Ontario International Airport (ONT) (Fig. 4), mild westerly winds can be found between 2 and $4 \mathrm{~ms}^{-1}$.

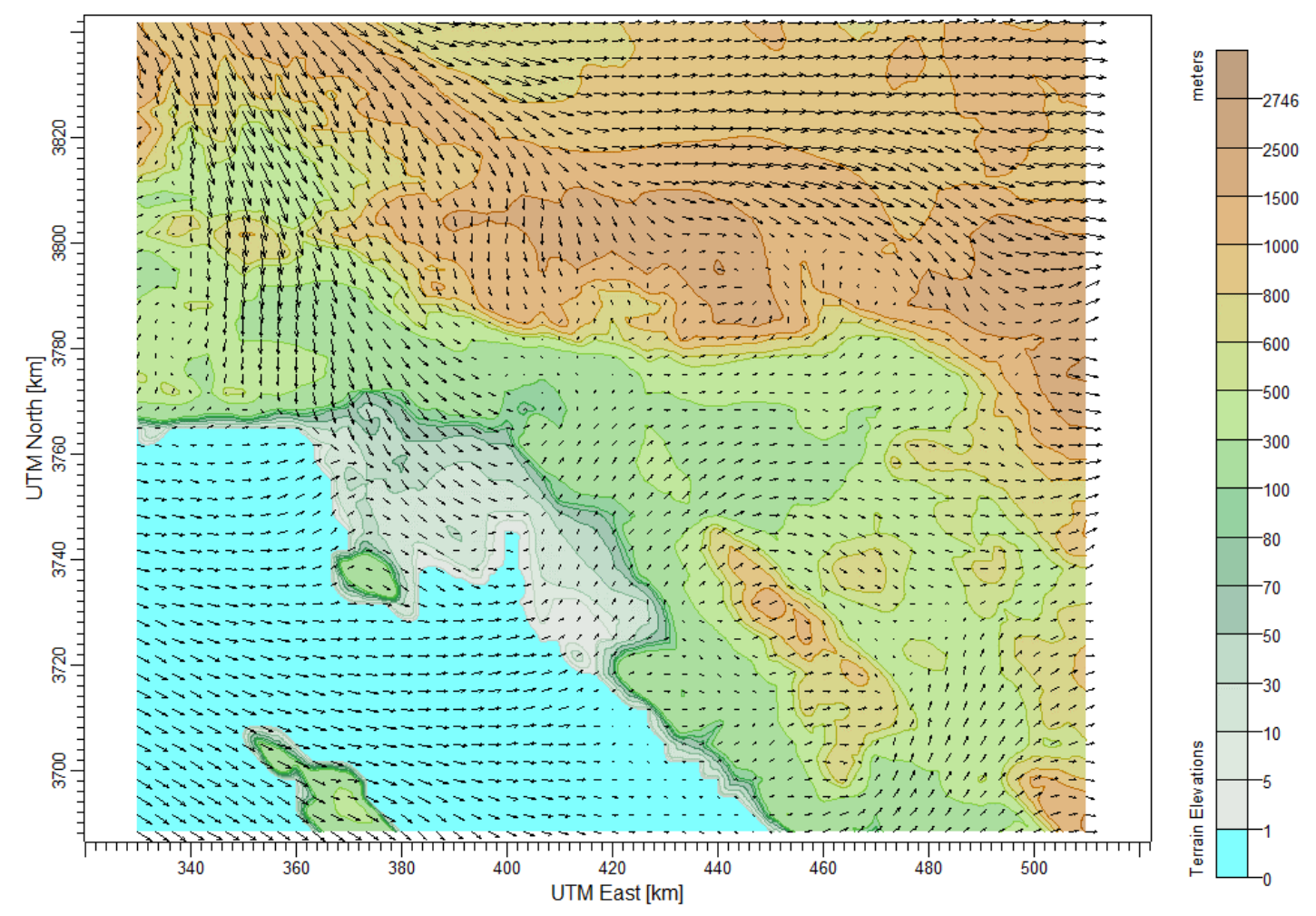

Fig. 16. CALMET 10-meter wind vectors extracted from WRF simulation on 20 October 20071900 UTC. 

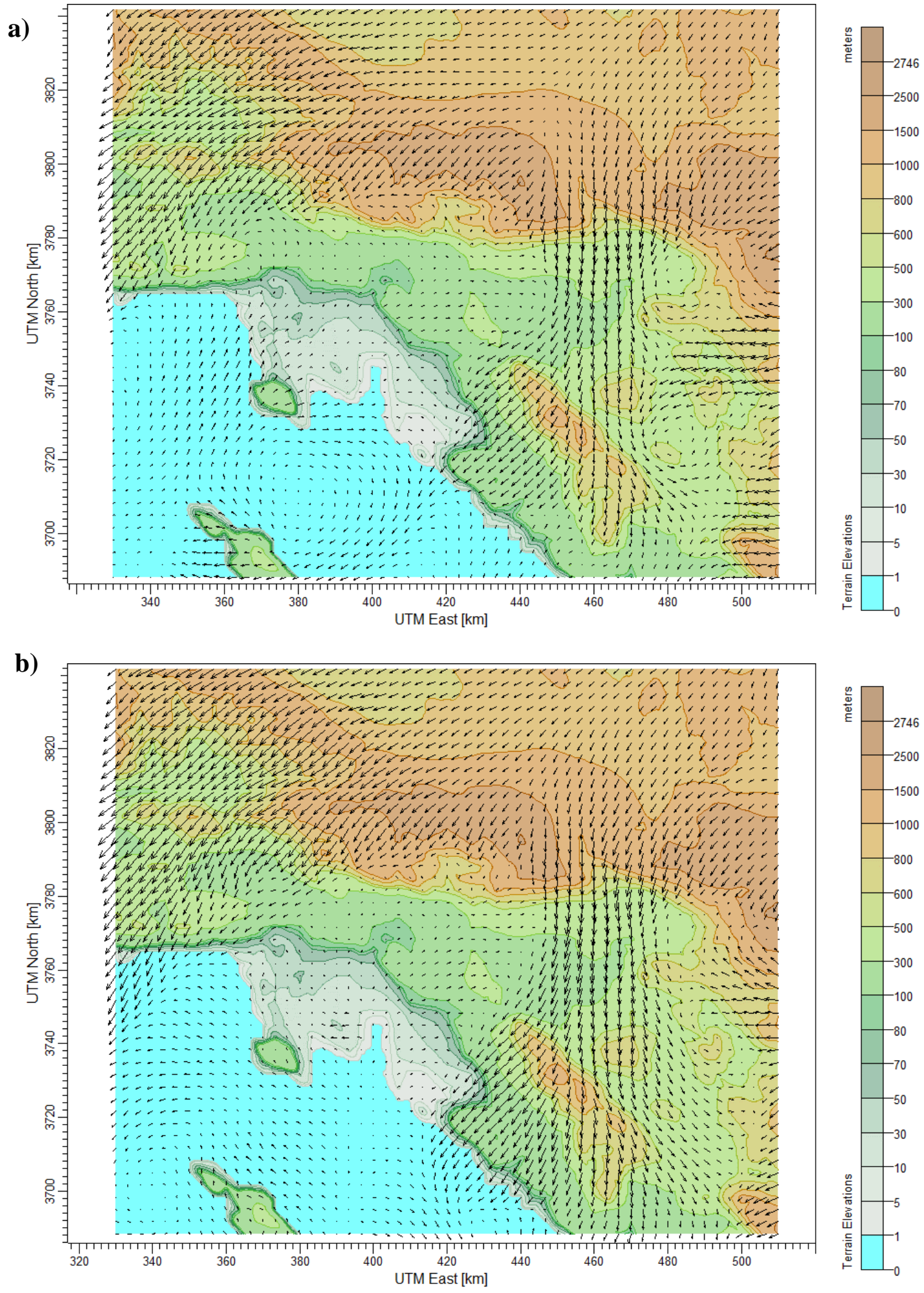

Fig. 17. Continued for (a) 21 October 2007 and (b) 23 October 20071900 UTC. 
On October $21^{\text {st }}$ (Fig. 17a), there was a noticeable shift in wind direction and speed with winds coming from the northeast diverted around the Angeles National Forest and Mt. San Antonio and channeling through the Grapevine and Cajon Pass. Winds were northeasterly at the Grapevine Pass between 12 and $18 \mathrm{~ms}^{-1}$ and northerly at the Cajon Pass at speeds between 10 and $14 \mathrm{~ms}^{-1}$ Winds passing through the Cajon Pass continued offshore, reaching the Orange County coastline at speeds between 10 and $16 \mathrm{~ms}^{-1}$ along the way. Winds at ONT were northeasterly between 6 and $8 \mathrm{~ms}^{-1}$.

On October $23^{\text {rd }}$ (Fig. 17b), winds continued its pattern channeling through the Grapevine and Cajon Pass, diverting around Angeles National Forest and Mt. San Antonio and continued offshore.

By October $25^{\text {th }}$ (Fig. 18a), a change in wind speed and direction throughout Southern California was visible. Most winds north of Angeles National Forest and Mt. San Antonio shifted northwesterly. An onshore flow was apparent, spreading inland to the Cajon Pass where it experienced both southerly winds at the south end and northwesterly winds at the north end. Wind speeds were between 0 and $4 \mathrm{~ms}^{-1}$ throughout the region. ONT experienced another shift in wind direction with winds coming from the northwest.

On October $27^{\text {th }}$ (Fig. 18b), an onshore flow from the south made its way into the Los Angeles Basin at speeds between 0 and $4 \mathrm{~ms}^{-1}$. Southerly winds were apparent at the Grapevine and Cajon Pass while ONT had a new shift in wind direction, from the southwest. 

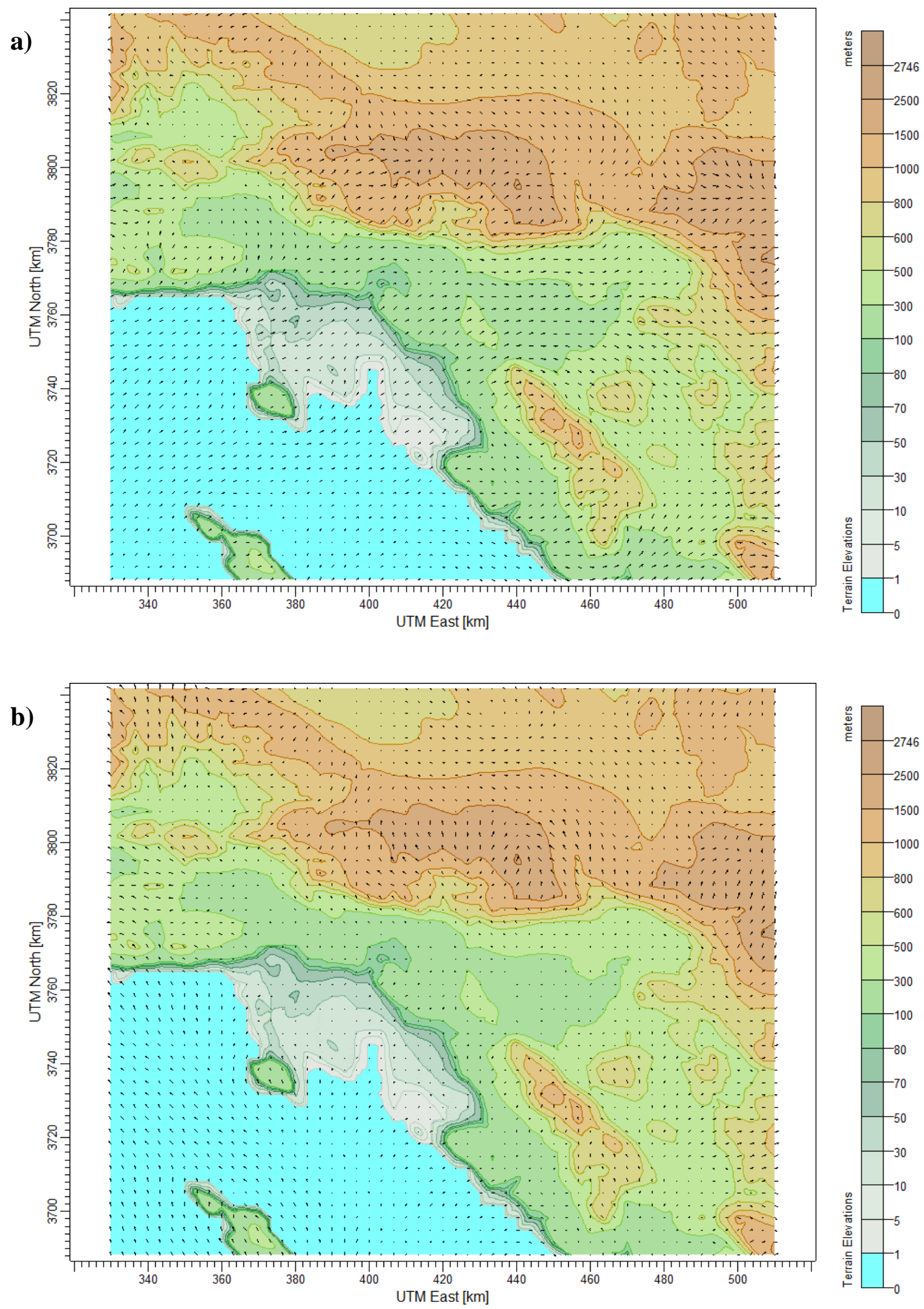

Fig. 18. Continued for (a) 25 October 2007 and (b) 27 October 20071900 UTC. 


\subsection{GIS and CALPUFF Modeling}

Fig. 19 displays fires that burned over 175 acres between 20 and 31 October provided by the Air Resources Board. Georeferenced fire "footprints" (polygons of total area burned) were retrieved from an interagency wild and prescribed fire geodatabase (FRAP 2012). Data included location, final extent of the fire perimeter (burn area), timing, and other attributes associated with wildfires. The geodatabase classifies wildfires according to management objective: suppression or non-suppression (wildfire use for resource benefit).

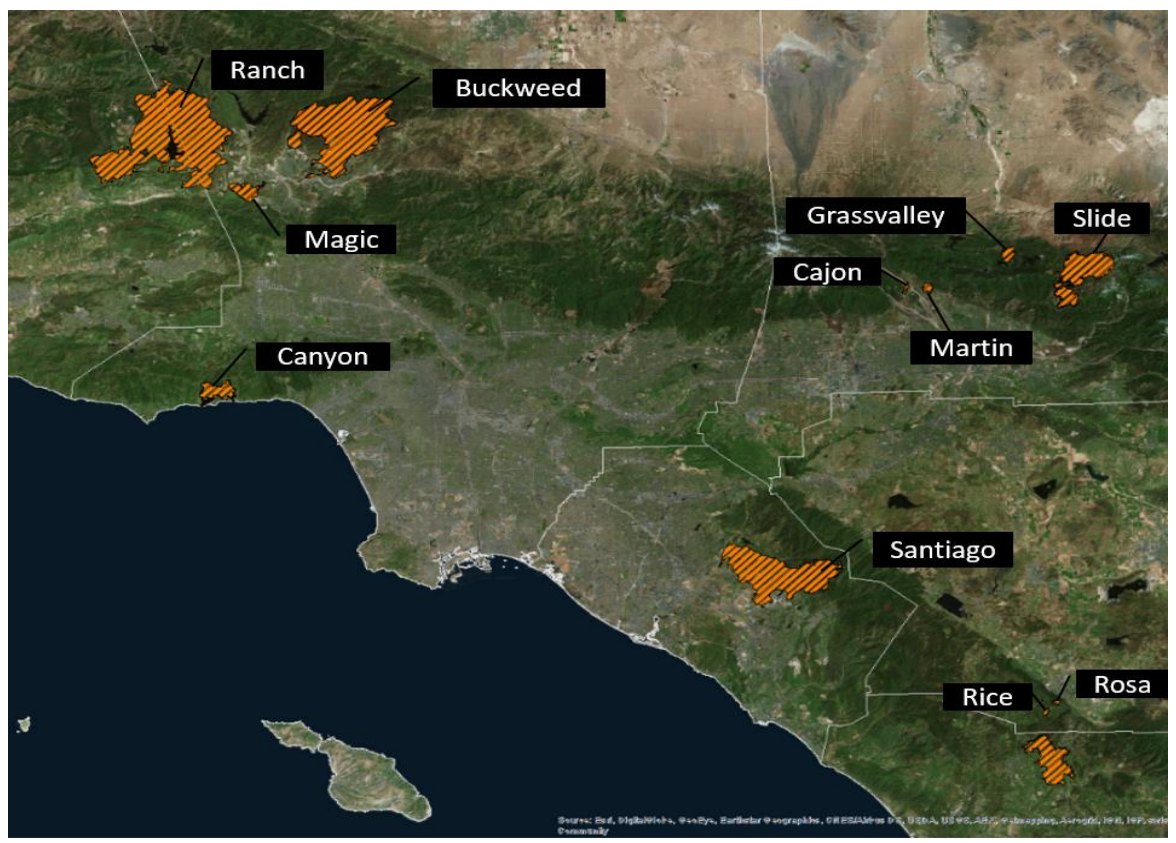

Fig. 19. GIS "footprints" (polygons of total area burned) of wildfires for Southern California from 20-Oct-07 to 31-Oct-07. (Air Resources Board, 2015).

Satellite imagery by NASA (Fig. 20), shows the behavior of smoke plumes between 23 and 25 October. It is apparent that the smoke plume was being blown offshore on October $23^{\text {rd }}$ (Fig. 20a). On October $24^{\text {th }}$ (Fig. 20b), a shift in wind caused the plume to 
diffuse closer to the fires and recirculated the smoke onshore. By the $25^{\text {th }}$ (Fig. 21a), winds are weaker (Fig. 18a), and the offshore marine layer forced the smoke back over land. On October $26^{\text {th }}$ (Fig. 21b), plumes veered northward.

a)

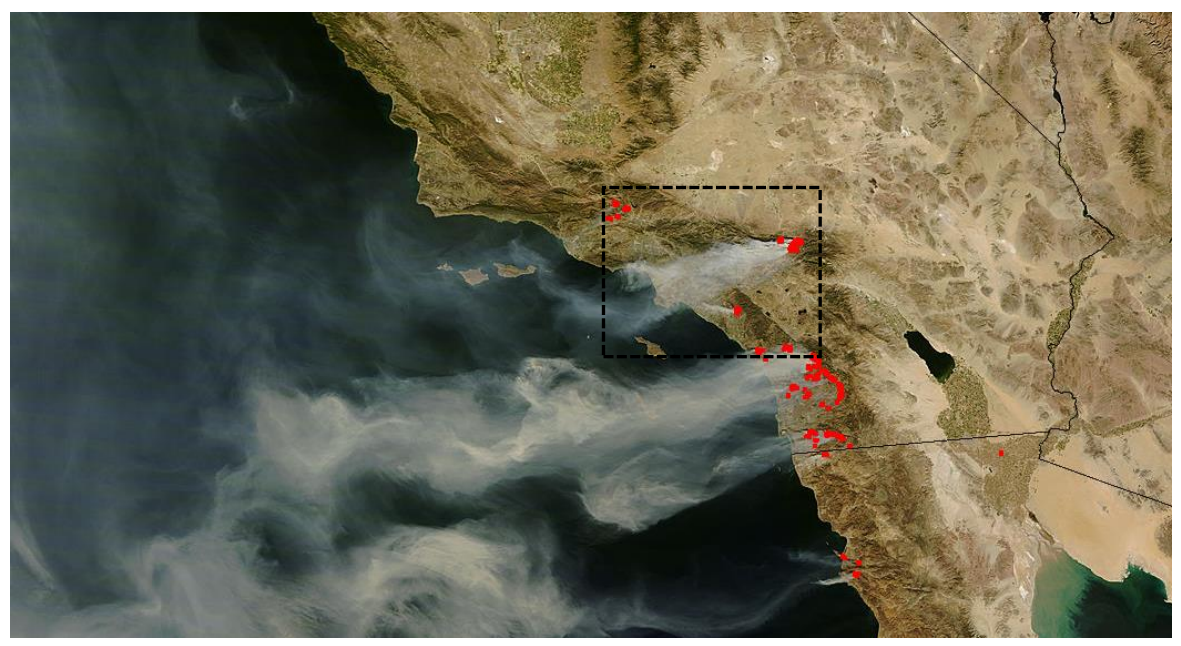

b)

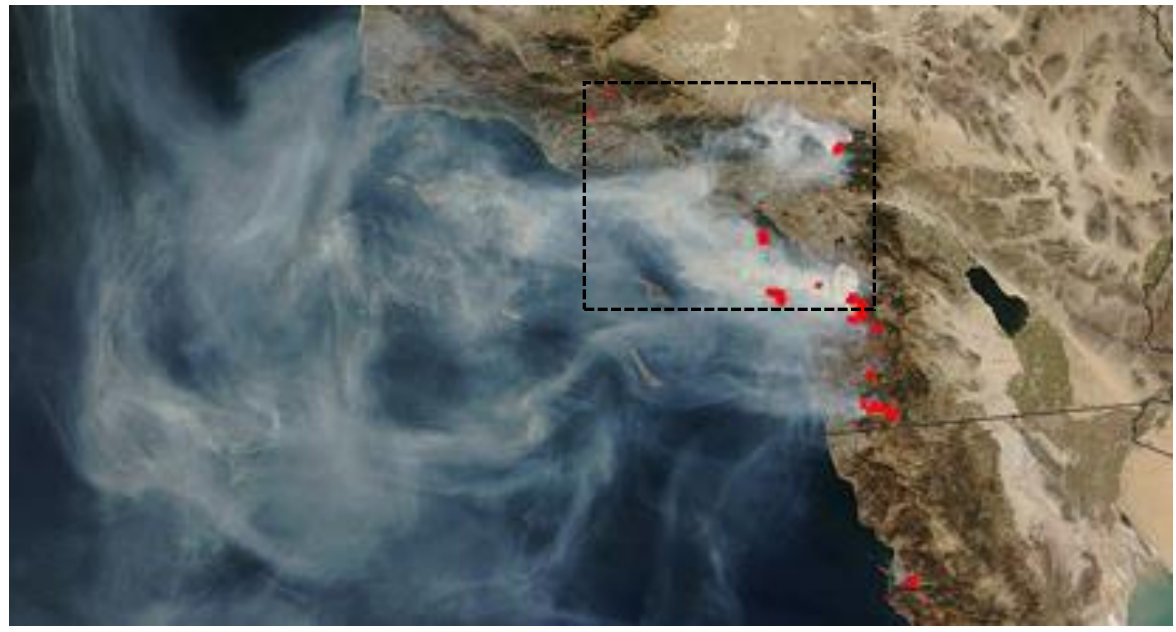

Fig. 20. NASA's Terra Satellite passage over southern California on (a) 23-Oct-2007 1825 UTC (b) 24-Oct-2007 1910 UTC. 
a)

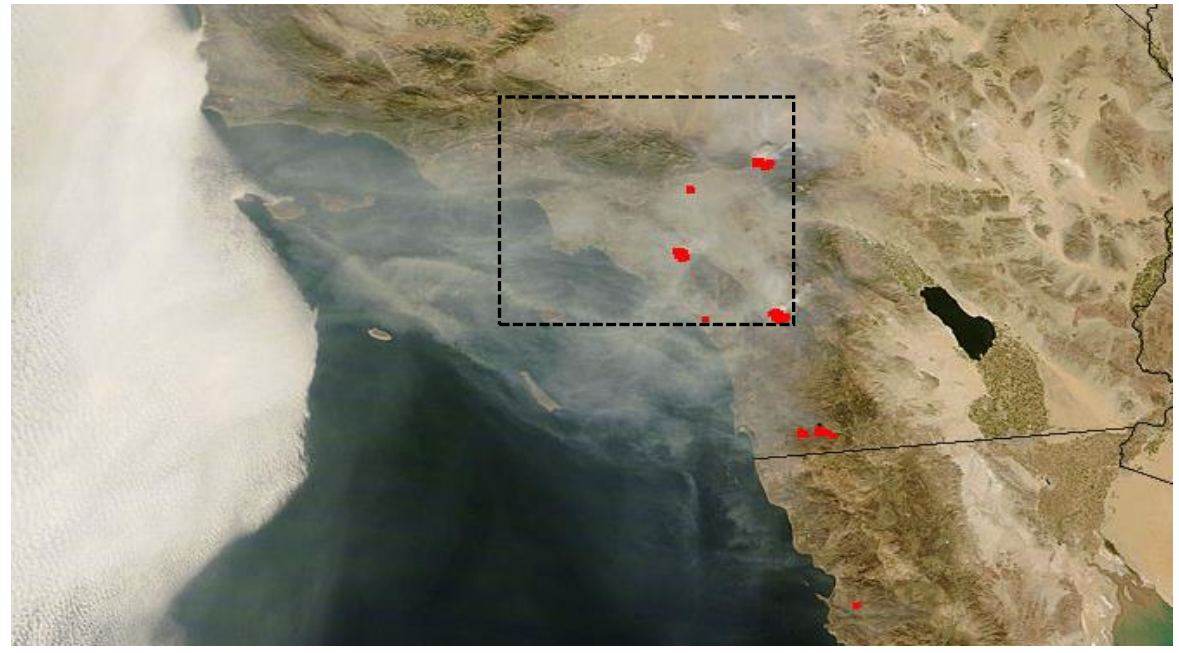

b)

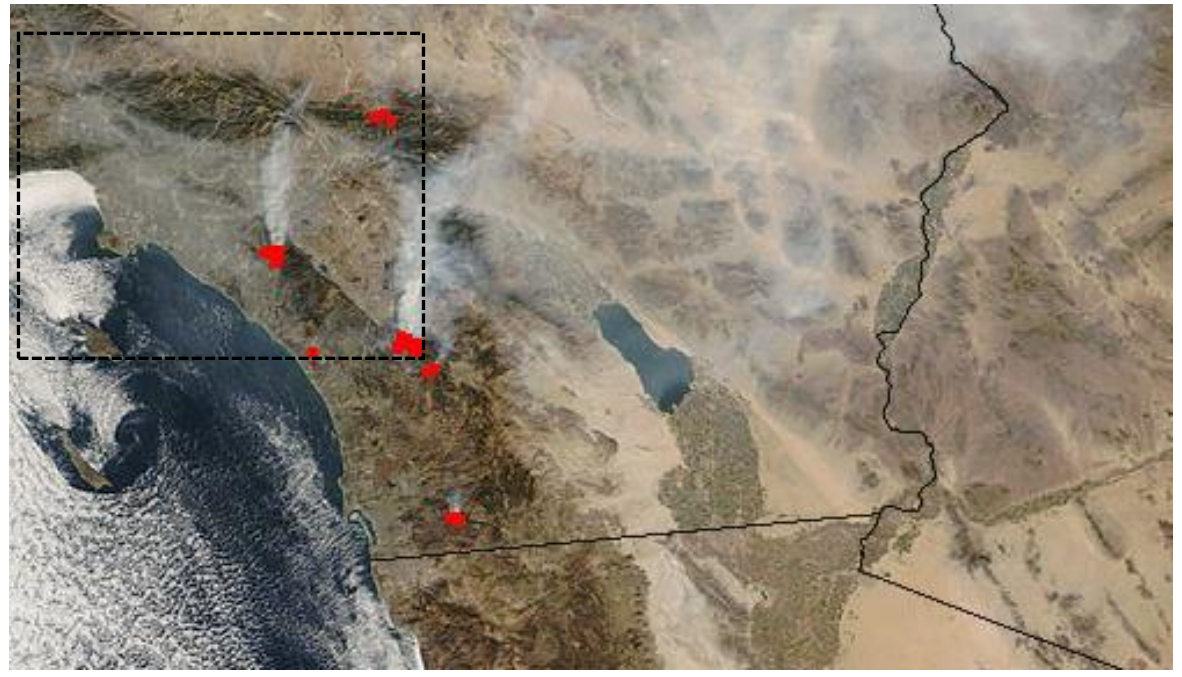

Fig. 21. Continued for (a) 25-Oct-2007 1815 UTC and (b) 26-Oct-2007 1855 UTC.

The plume for all four schemes on October $23^{\text {rd }}$ (Fig. 22), appeared qualitatively similar to the satellite image (Fig. 20a), and their directions were alike. The ISC scheme had the highest levels of $\mathrm{PM}_{2.5}$ at the Buckweed and Ranch fire sites, up to $2000 \mu \mathrm{gm}^{-3}$. Compared to satellite observations (Fig. 20a), simulations of the plume appeared slightly toward the south. The difference was likely due to wind effects. In addition, it is uncertain from looking at satellite imagery how high the plume was in the atmosphere. 
a)

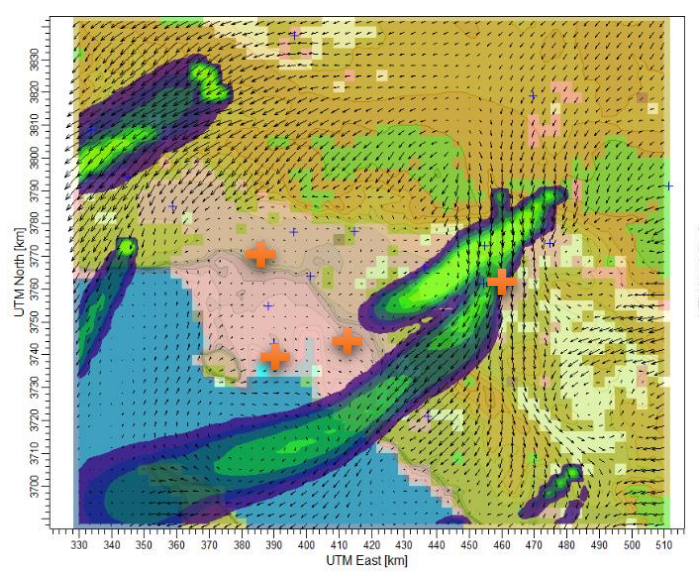

c)

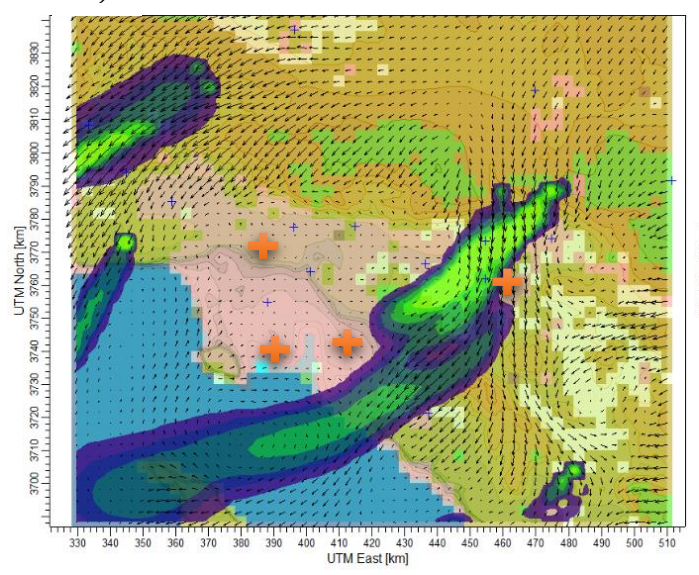

b)

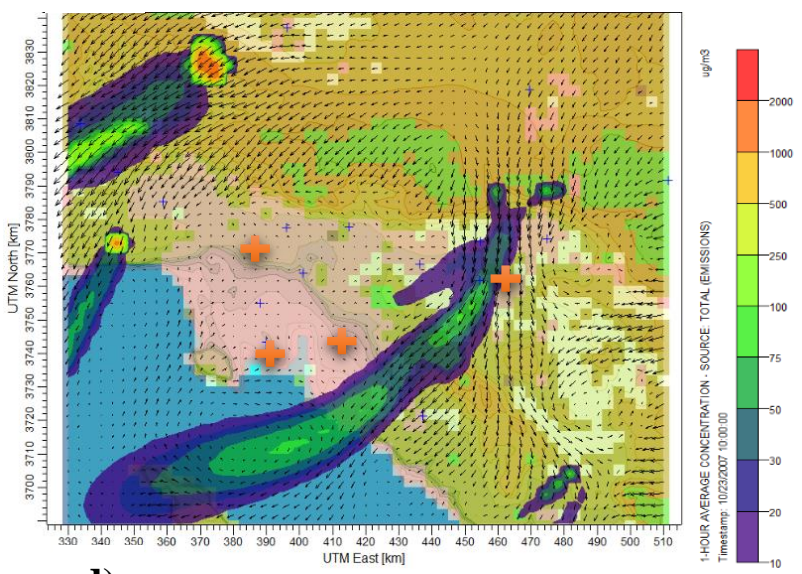

d)

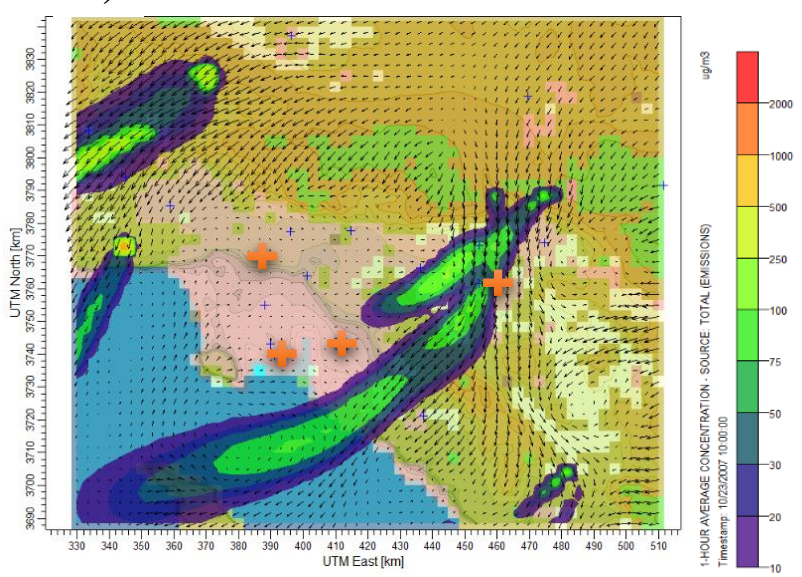

Fig. 22. 23 October 20071800 UTC 10-meter height 1-hour average Total Emissions Concentrations for complex terrain effects options (a) No Adjustment (b) ISC Adjustment scheme (c) CALPUFF Adjustment scheme (d) Partial Plume Path Adjustment with wind vectors, land use, and terrain elevations.

On October $24^{\text {th }}$ (Fig. 23), most of the plumes diminished and dispersed laterally, likely due to the decrease in Santa Ana winds. Canyon fire (Fig. 19), was fully contained with no plume visible. The CALPUFF scheme appeared to have a greater dispersal impact from the Cajon and Martin fires compared to the other schemes. Ranch, Buckweed, and Magic fires had $\mathrm{PM}_{2.5}$ levels close to its source between 250-2000 $\mu \mathrm{gm}^{-3}$, the highest levels compared to all other fires. Satellite observations (Fig. 20b), showed a 
steady plume recirculation throughout the region, including smoke from the San Diego county fires, but were not visible within the domain.

a)

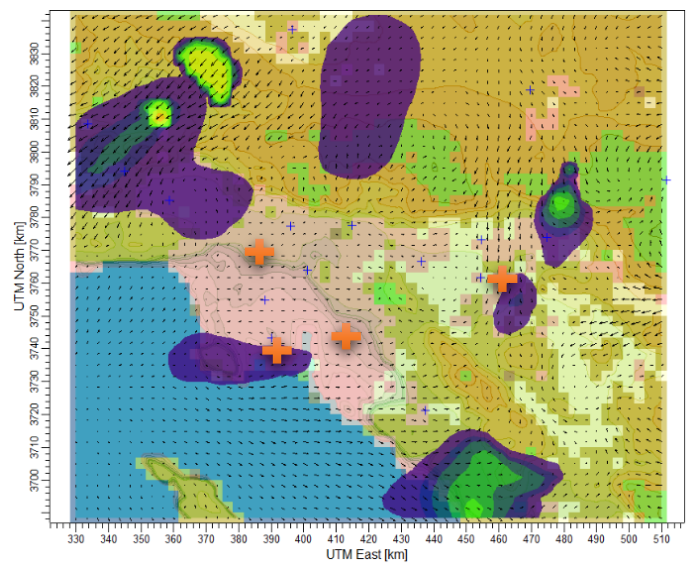

c)

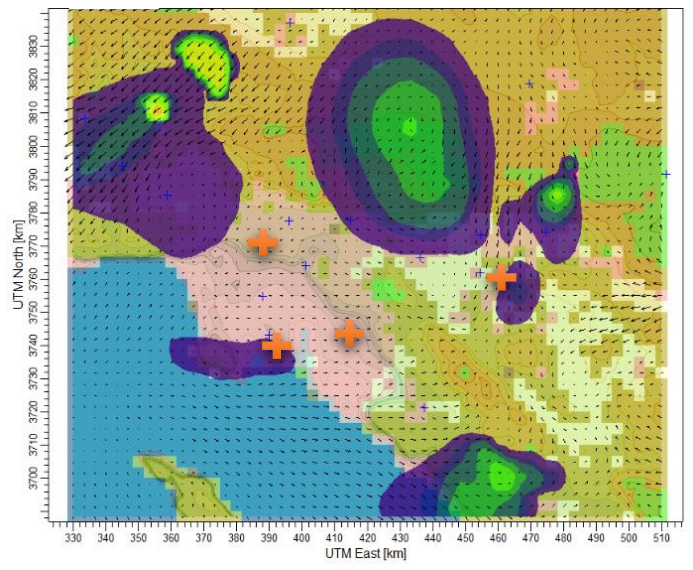

b)

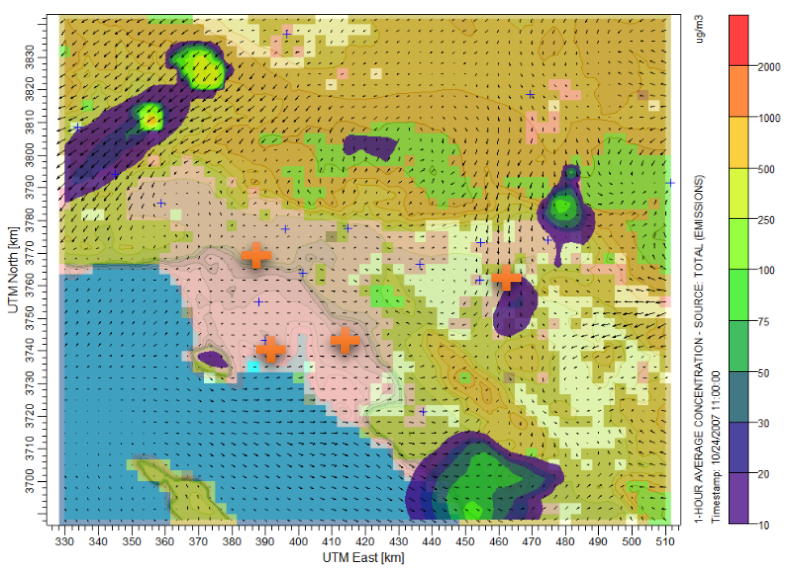

d)

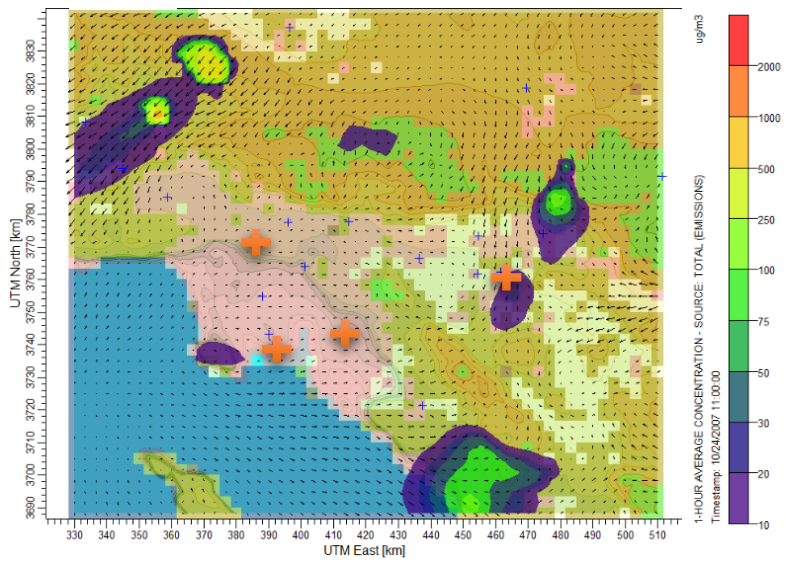

Fig. 23. Continued for 24 October 20071900 UTC.

On October $25^{\text {th }}$ (Fig. 24), winds shifted and speeds were close to zero (Fig. 18a). The CALPUFF scheme modeled greater plume dispersal from the Slide and Grassvalley fires that extended to the Orange County coasts. Compared to satellite observations (Fig. 21a), smoke continued to be re-circulated from the San Diego County fires into the domain but such smoke was not visible in the runs. The Rubidoux ground receptor (Fig. 
29), showed an increase in $\mathrm{PM}_{2.5}$ levels whereas the models did not capture that increase, likely due to the recirculation of smoke.

a)

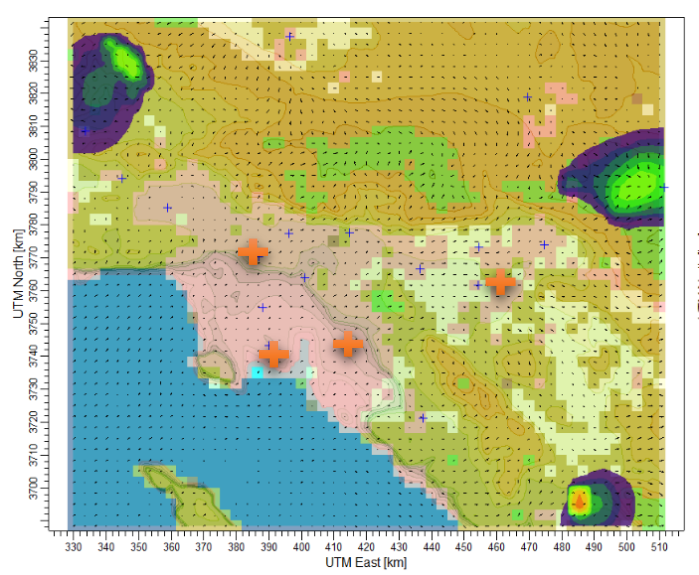

c)

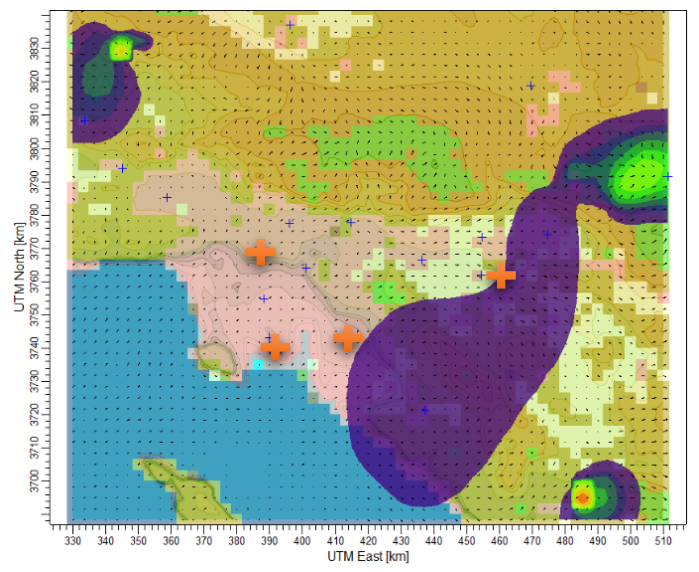

b)

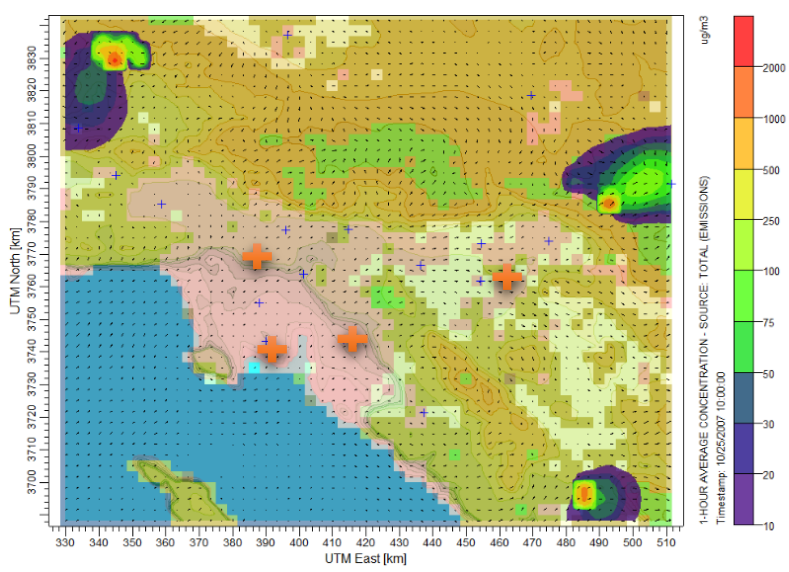

d)

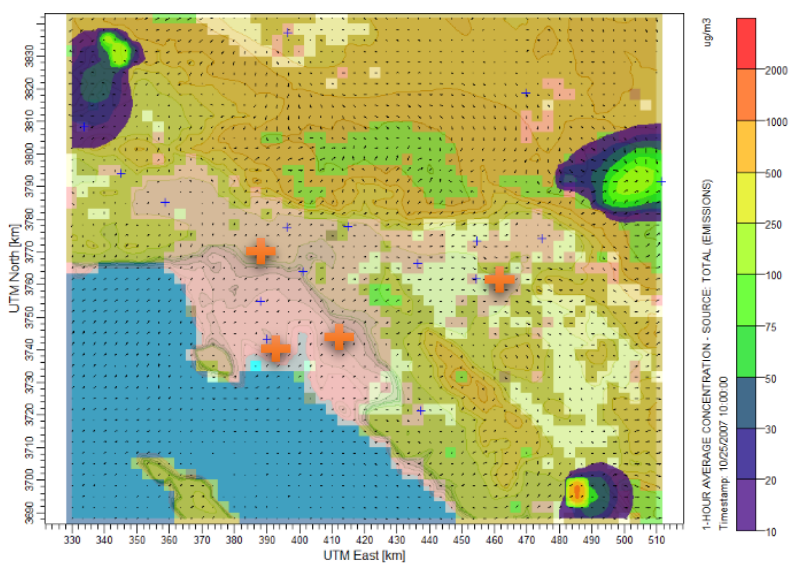

Fig. 24. Continued for 25 October 20071800 UTC.

By October $26^{\text {th }}$ (Fig. 25), very little of the fires remain, with plumes being shifted northward consistent with satellite observations (Fig. 21b), and wind observations. However, the time series (Fig. 26-29), for ground observations showed higher $\mathrm{PM}_{2.5}$ levels than all modeled runs. Because winds shifted northward, smoke from San Diego 
county fires made its way into the domain, only visible on satellite but not in any of the runs.

a)

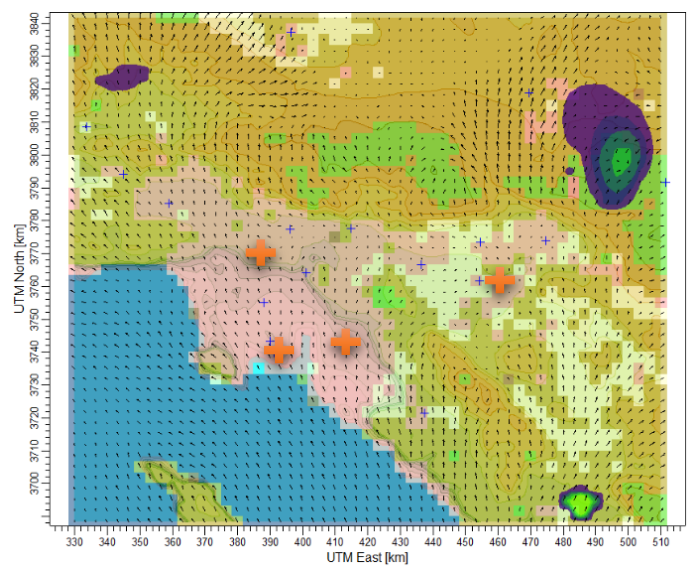

c)

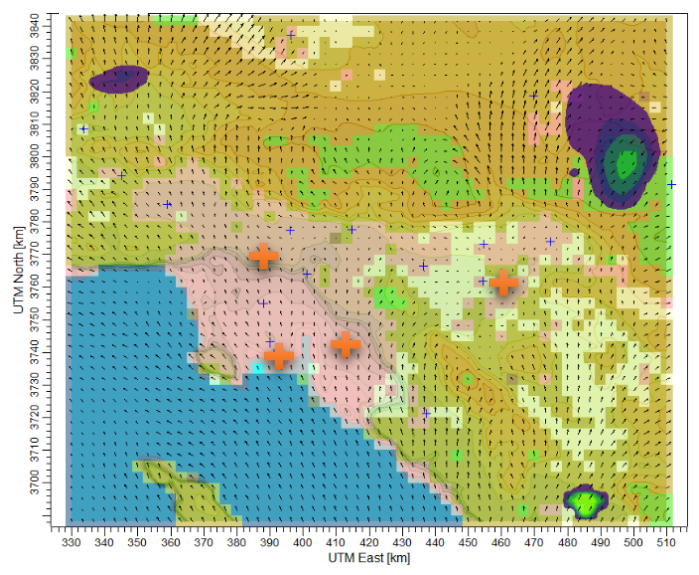

b)

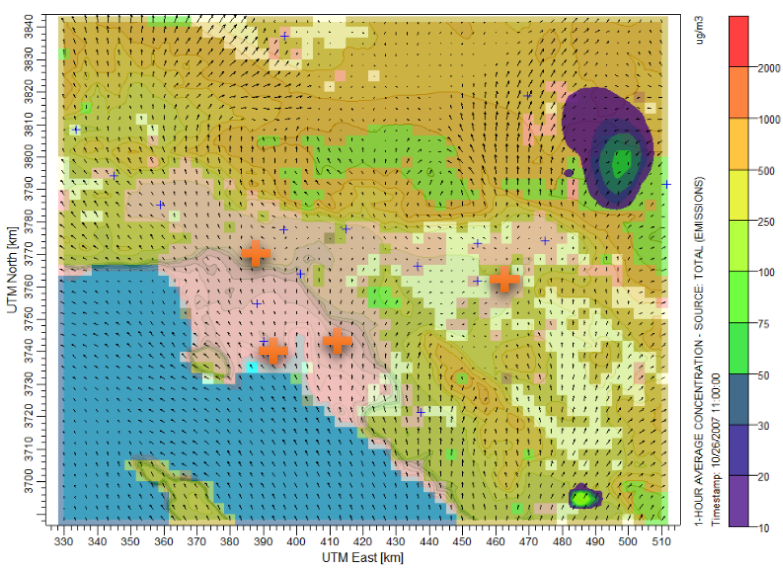

d)

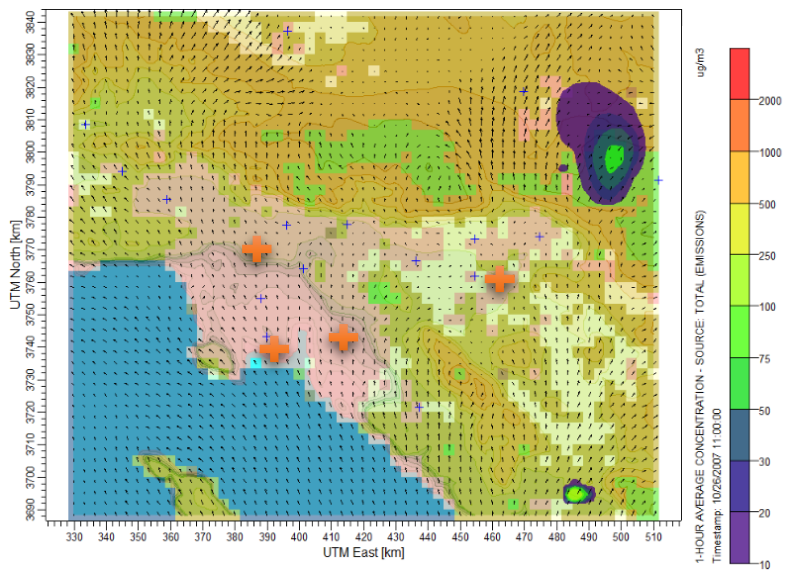

Fig. 25. Continued for 26 October 20071900 UTC.

Time series of daily mean $\mathrm{PM}_{2.5}$ concentrations and their difference between observed and modeled levels are shown in Fig. 26 through 29 for ground observations and all four terrain adjustment schemes. As reference, the NAAQS for $\mathrm{PM}_{2.5}$ was plotted. It is important to note that $\mathrm{PM}_{2.5}$ devices vary between filter and continuous monitoring. Filter device measurements are usually conducted every $3^{\text {rd }}$ day as opposed to daily measurements by continuous monitoring devices. Of the 20 receptor points modeled, we 
focused on sites that provided $80 \%$ or more data for ground observations during the 7-day period. Rubidoux (Fig. 29), was the only site with continuous monitoring and available measurements.

Background values were computed per county by using the average $\mathrm{PM}_{2.5}$ for all October months (2007-2009). The following formula was used to find the difference between ground observation and modeled $\mathrm{PM}_{2.5}$ :

$$
\Delta=\text { Observed-(modeled }+ \text { background) }
$$

The most significant differences in estimates were visible between October $22^{\text {nd }}$ and October $24^{\text {th }}$. These differences were due to the small displacements in the dispersion of the plume. At the Anaheim site (Fig. 26), the CALPUFF scheme overestimated emissions on October $23^{\text {rd }}$ by a factor of nearly 2 , greater than all other schemes. CALPUFF again overestimated emissions at Los Angeles (Fig. 27), by a factor of 1 and Long Beach (Fig. 28), by a factor of 1.5. At the Rubidoux site (Fig. 29), the No Adjustment scheme had the greatest overestimation by a factor of over 2. The ISC scheme was the most conservative at Anaheim, Los Angeles, and Long Beach. The No Adjustment scheme was closest to the observed values at Anaheim and Long Beach, Partial Plume Path scheme at Los Angeles, and ISC scheme at Rubidoux. 


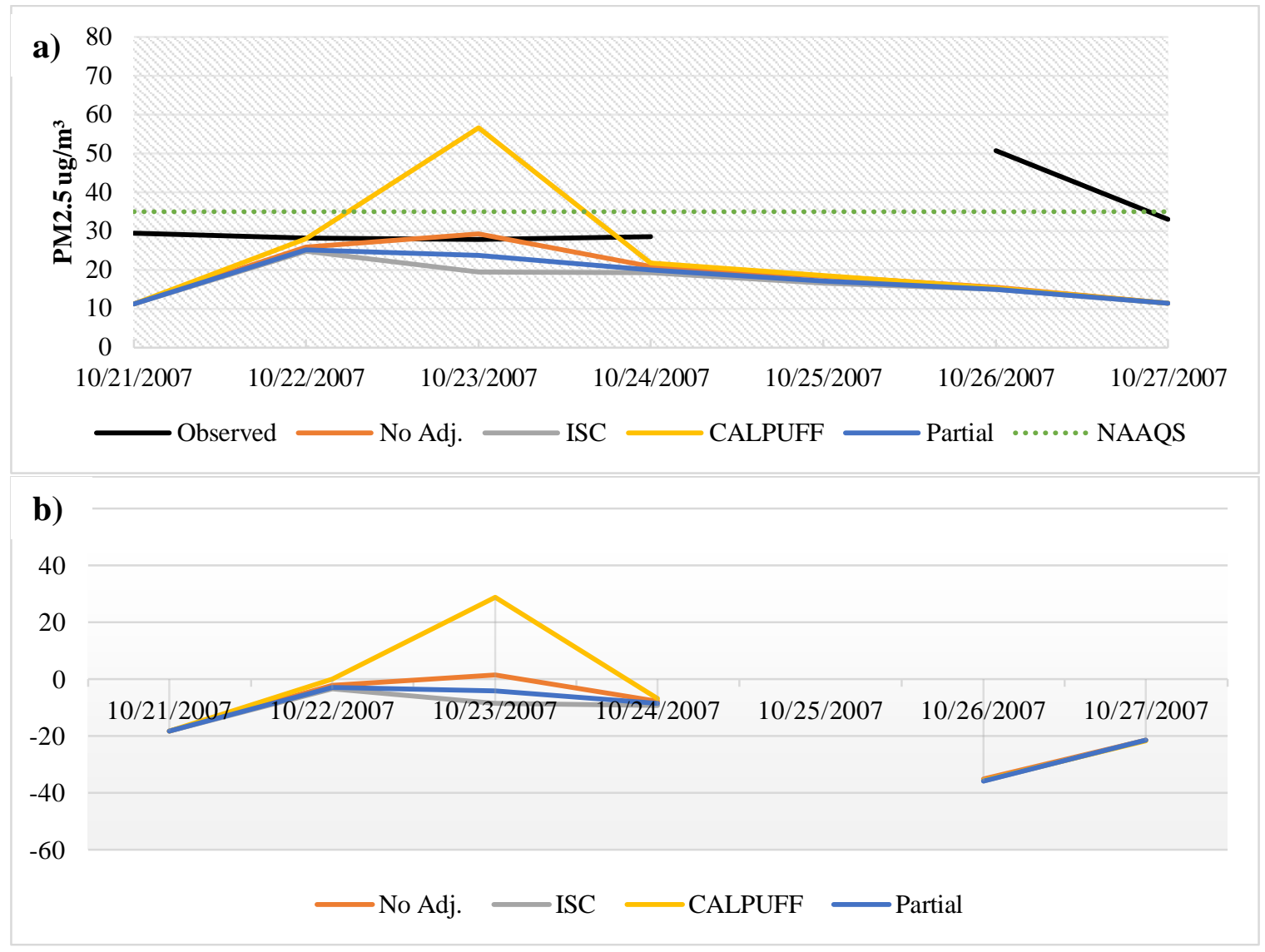

Fig. 26. (a)24-hour averaged time series of observed and modeled $\mathrm{PM}_{2.5}$ concentrations and (b) difference between observed and modeled concentrations for receptor site Anaheim from 21-Oct-07 to 27-Oct-07.

On October $24^{\text {th }}$ Anaheim, Long Beach, and Rubidoux, had predicted emissions for all four schemes at differences less than $10 \mu \mathrm{gm}^{-3}$ from ground observations. At the Los Angeles site ISC and Partial Plume Path schemes performed best at differences less than $4 \mu \mathrm{gm}^{-3}$.

From October $25^{\text {th }}$ and onward, all schemes had a similar trend with a near equivalent underestimation from the observed values by a factor of 1.5. These predictions included emissions from the wildfires within the domain but not the emissions from the 359,670 acres that burned in the San Diego region (Fig. 21). 


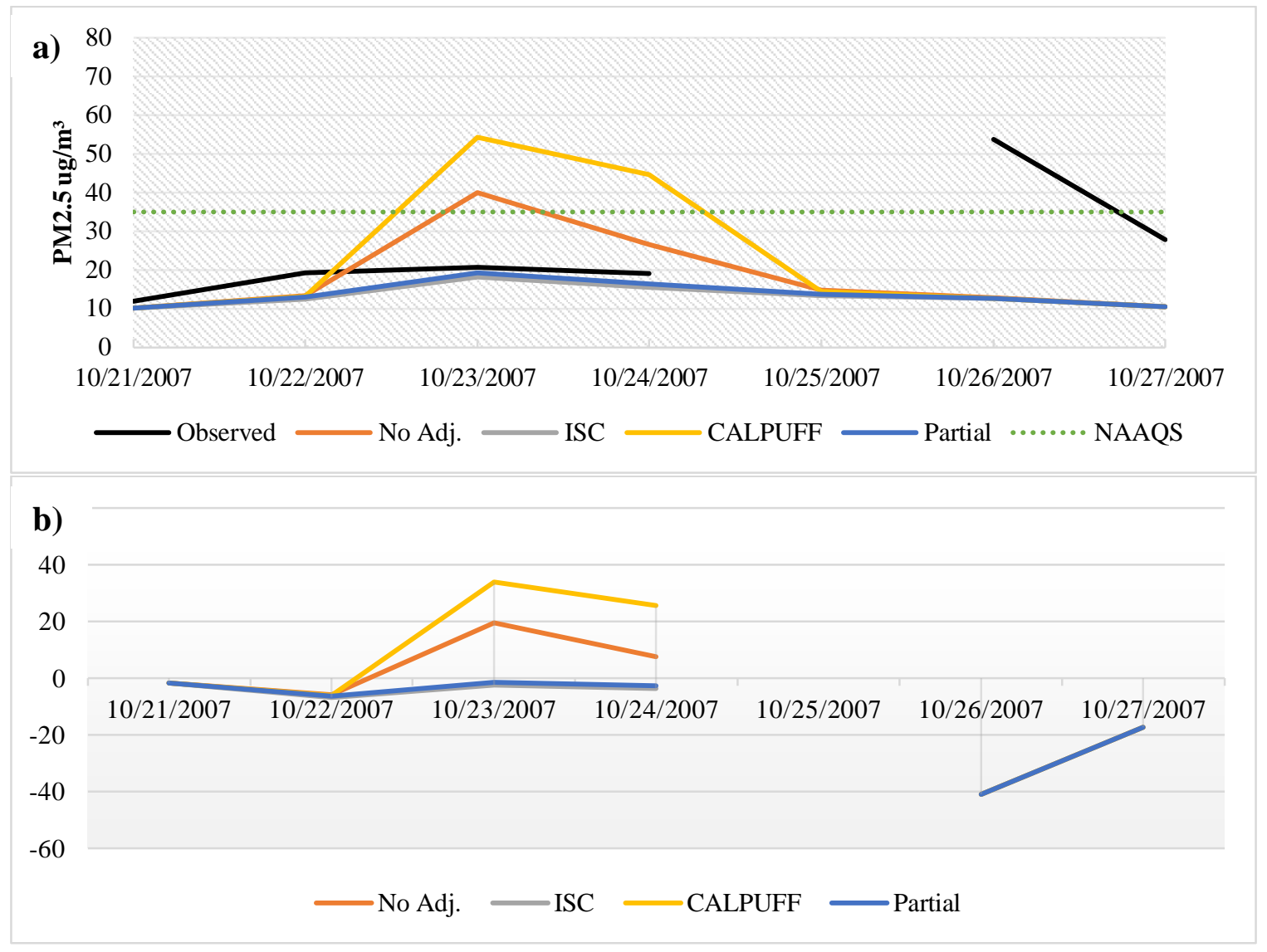

Fig. 27. Continued for Los Angeles.

Strictly looking at performance of the models two types of observations were noted. First, all four sites were evaluated daily between 21 and 27 October. The scheme with the smallest difference between the observed value and the modeled value on that day was marked. CALPUFF scheme performed best at the Anaheim and Long Beach sites, Partial Plume Path performed best at Los Angeles, ISC scheme performed best at Rubidoux. Second, we looked at individual days for all receptors whose ground observations were given between 21 and 27 October and noted all schemes whose difference were closest to the observed value and below $10 \mu \mathrm{gm}^{-3}$. Out of 19 available 
ground observations CALPUFF scheme performed best in 8 instances, No Adjustment and Partial Plume Path schemes tied at second with 4 instances each, and ISC scheme with 3.
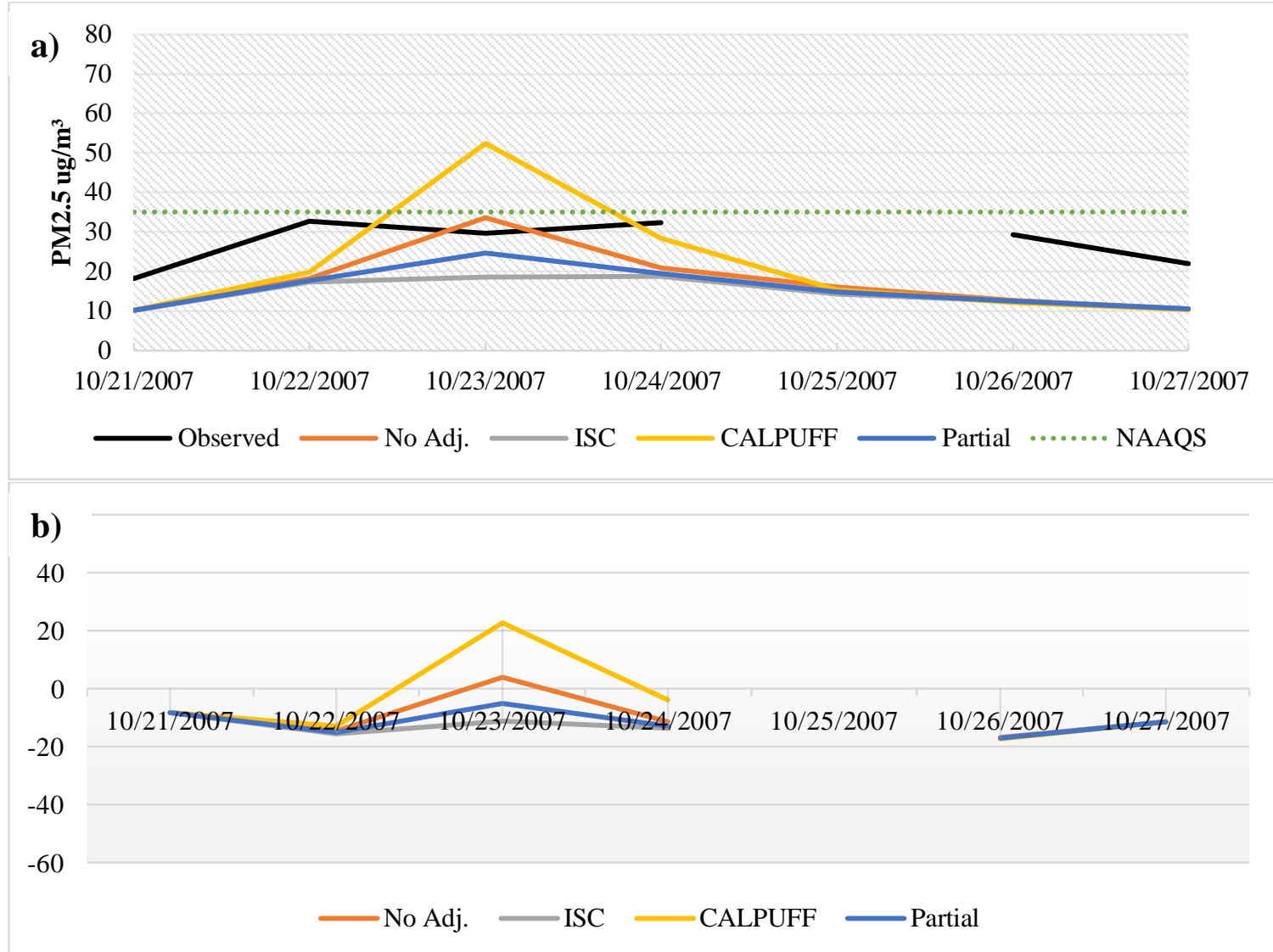

Fig. 28. Continued for Long Beach. 


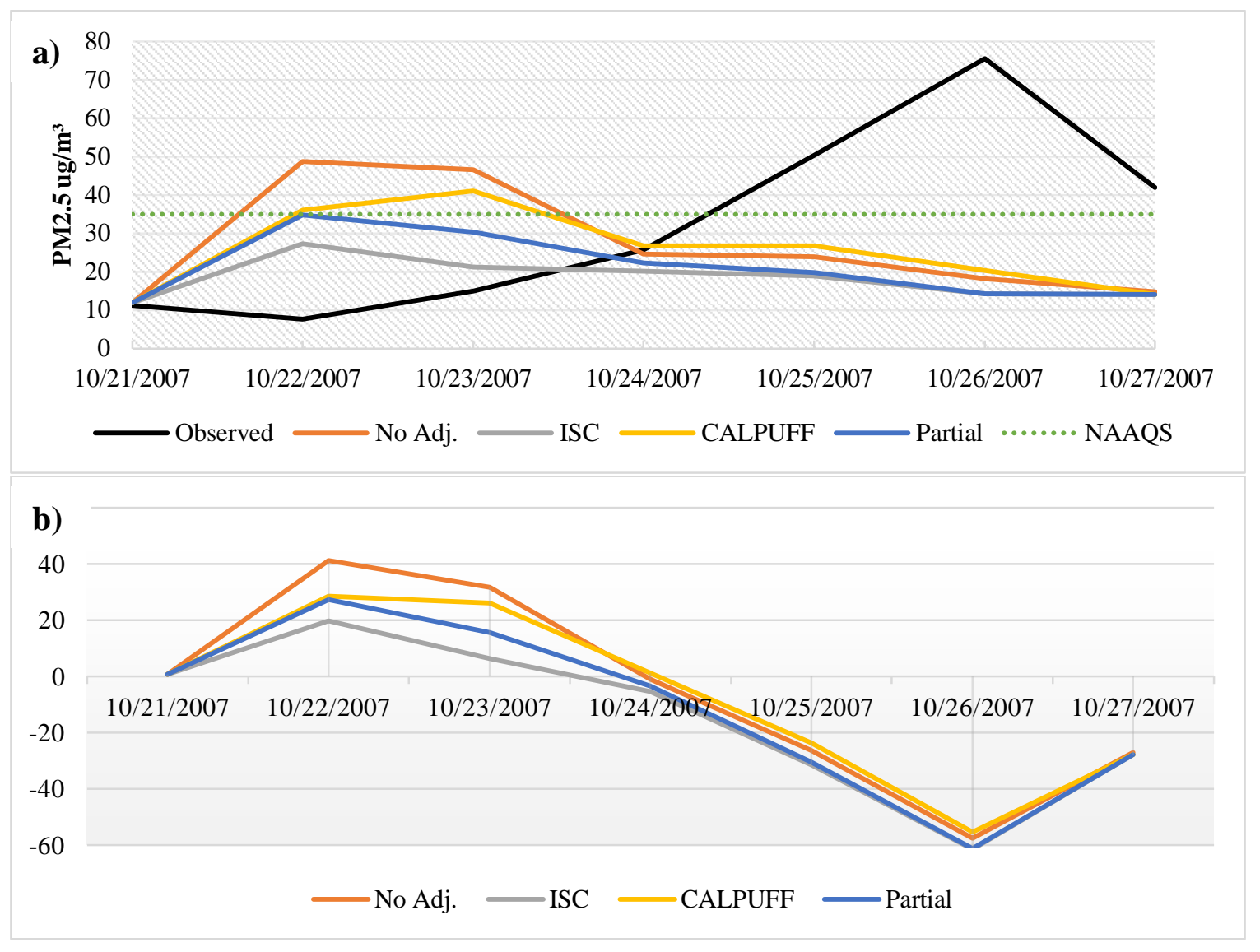

Fig. 29. Continued for Rubidoux. 
Fig. 30 through 32 show observed and modeled concentrations for all receptors on October $23^{\text {rd }}$. Four receptors had ground observations (Fig. 30), on this date with $\mathrm{PM}_{2.5}$ levels between 11 and $30 \mu \mathrm{gm}^{-3}$.

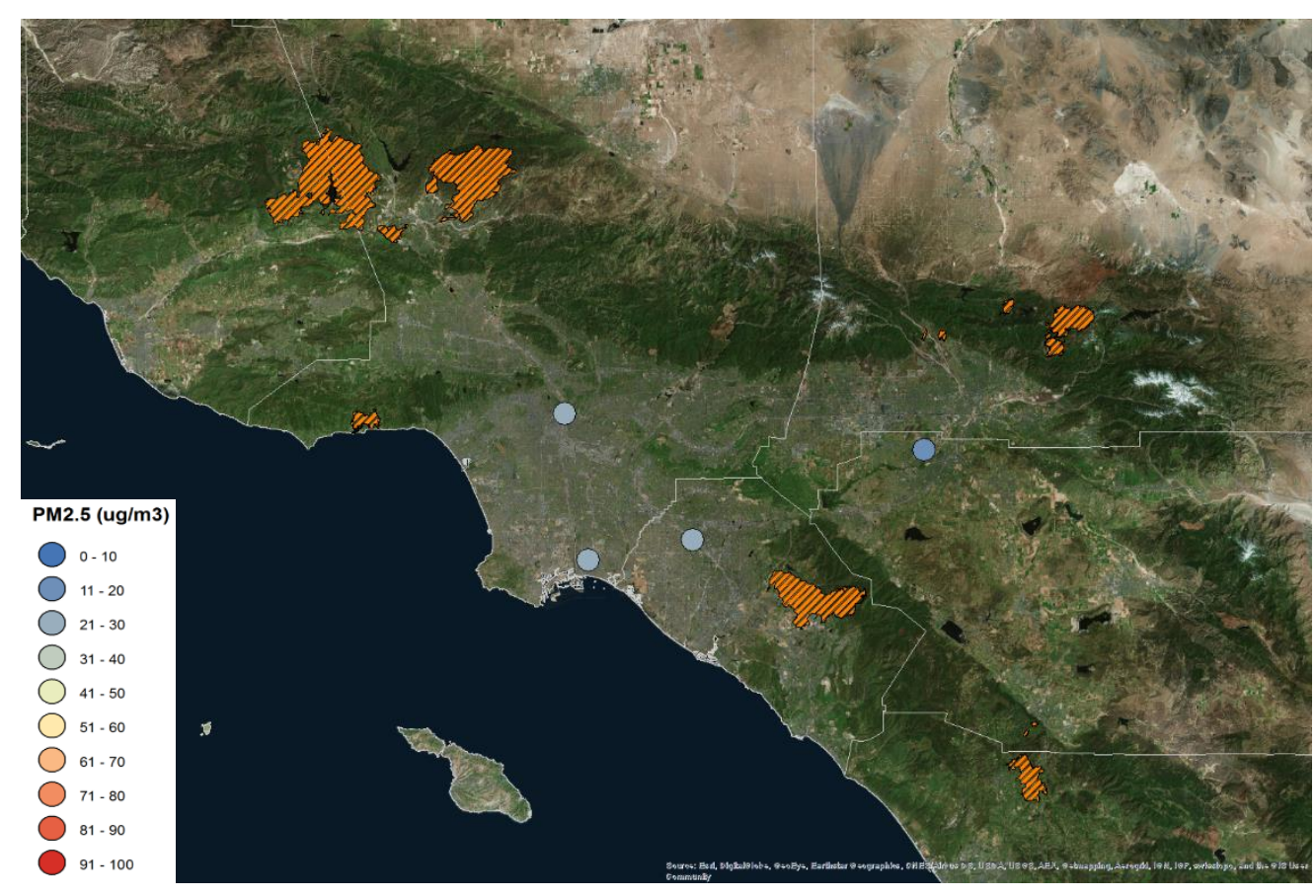

Fig. 30. 23 October 2007 24-hour average $\mathrm{PM}_{2.5}$ concentration values at selected receptors $\left(\mu \mathrm{g} / \mathrm{m}^{3}\right)$ for ground observations.

The ISC (Fig. 31b), and Partial Plume Path (Fig. 32b), schemes had levels

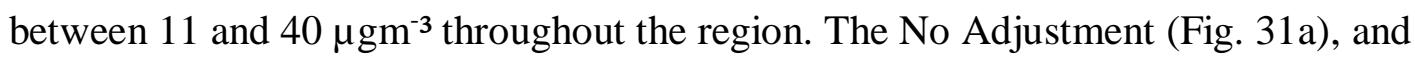
CALPUFF (Fig. 32a), schemes had more clearly defined areas of impact with levels modeled up to $100 \mathrm{\mu gm}^{-3}$. 
a)

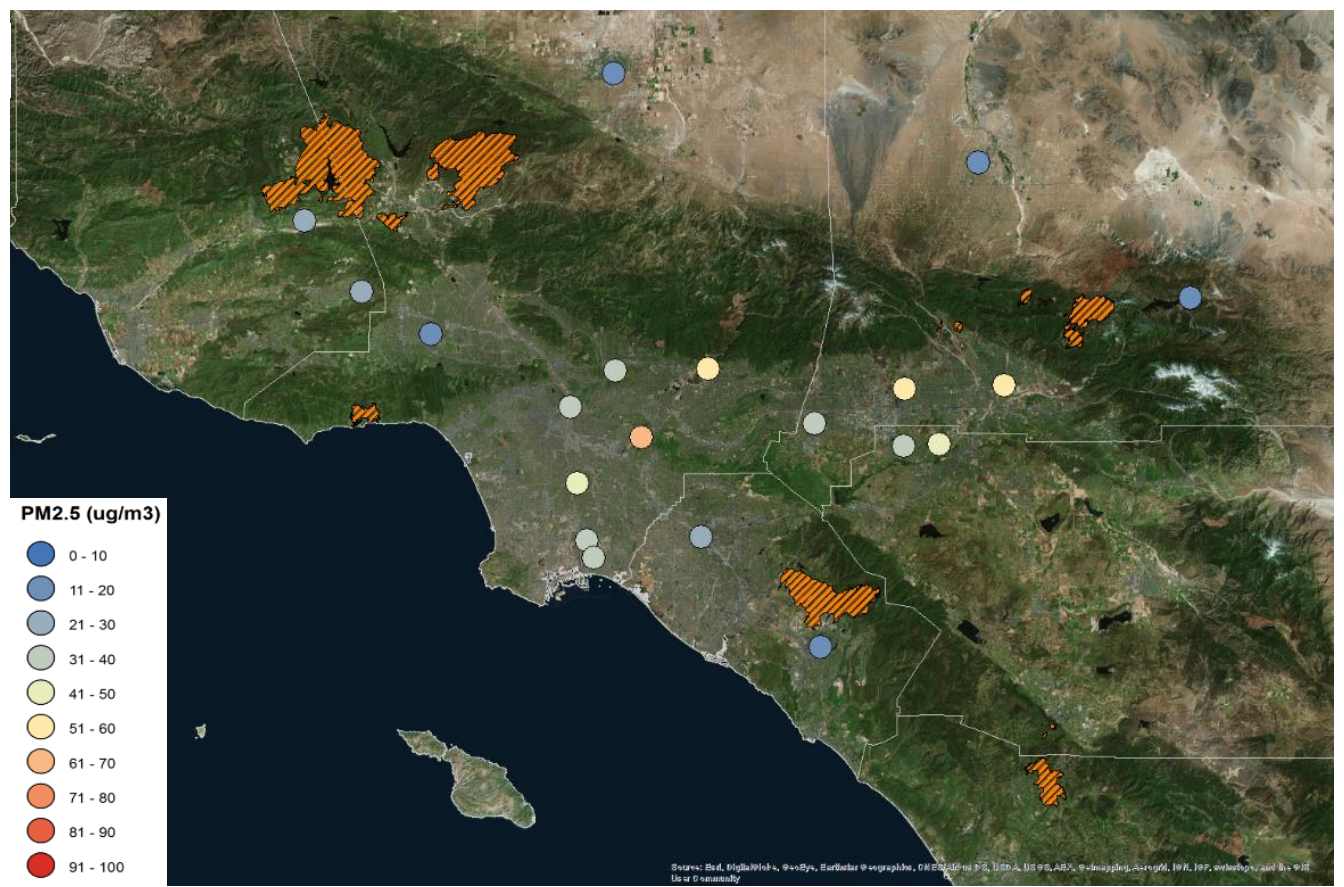

b)

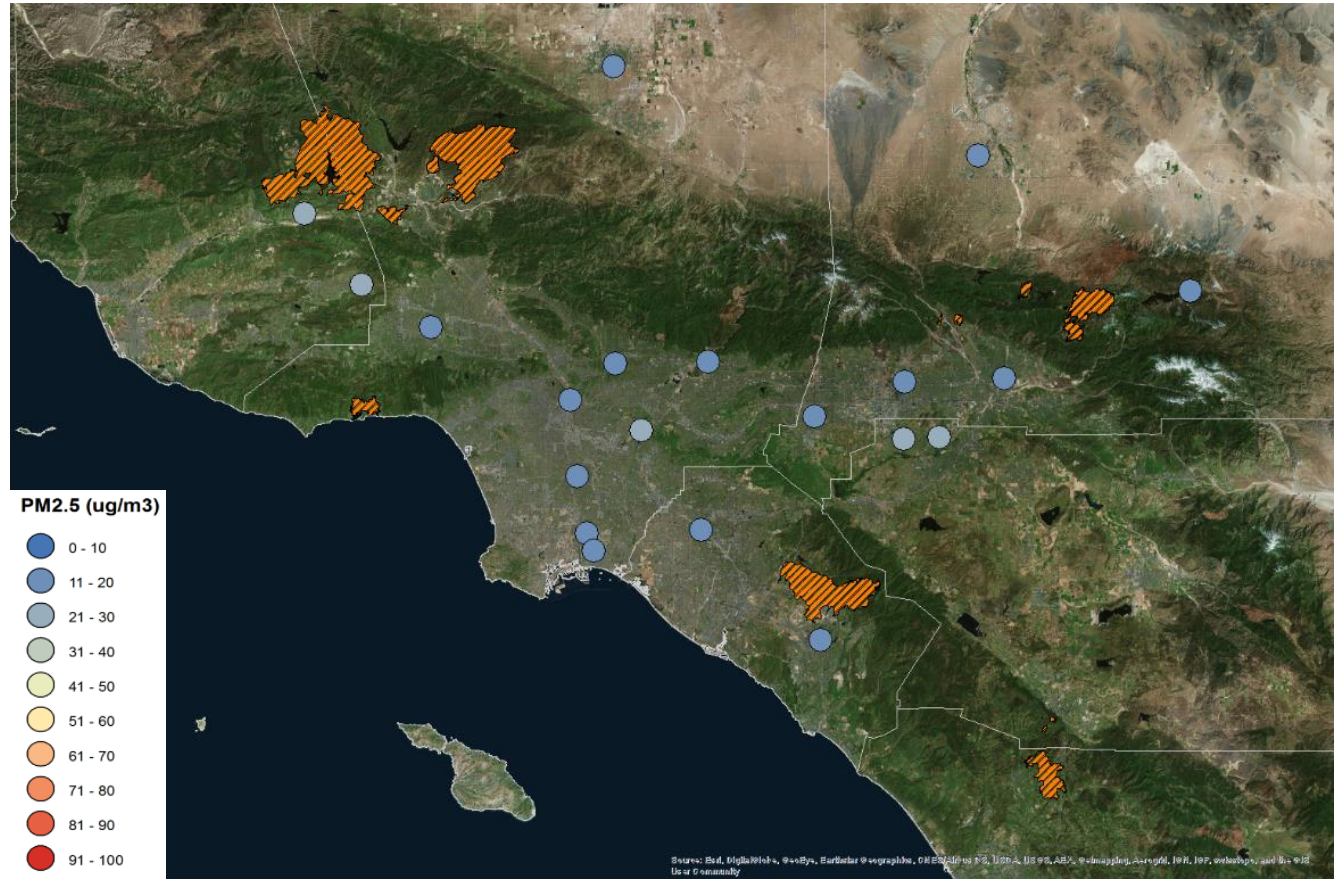

Fig. 31. Continued for (a) No Adjustment Scheme and (b) ISC Adjustment Scheme. 
a)

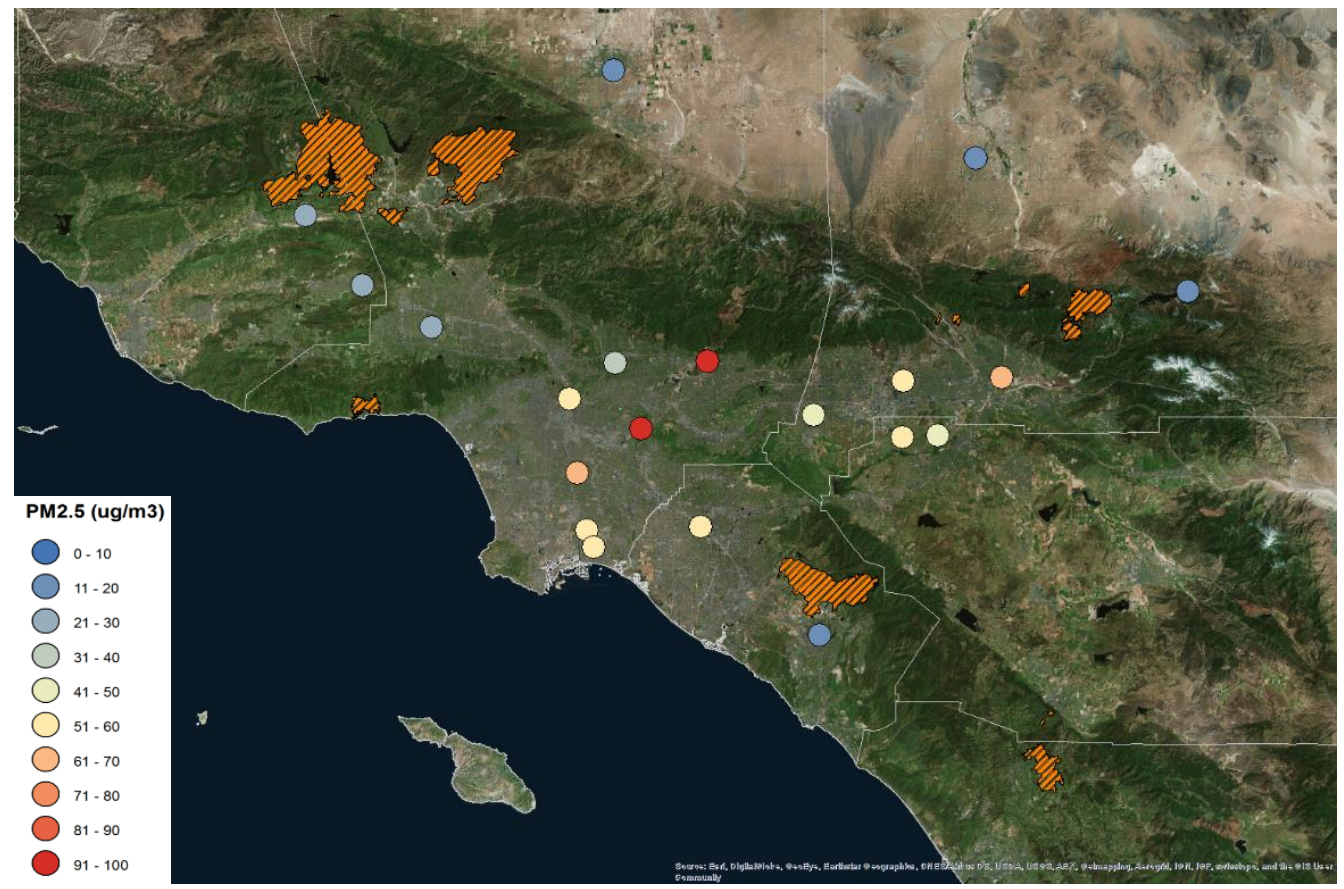

b)

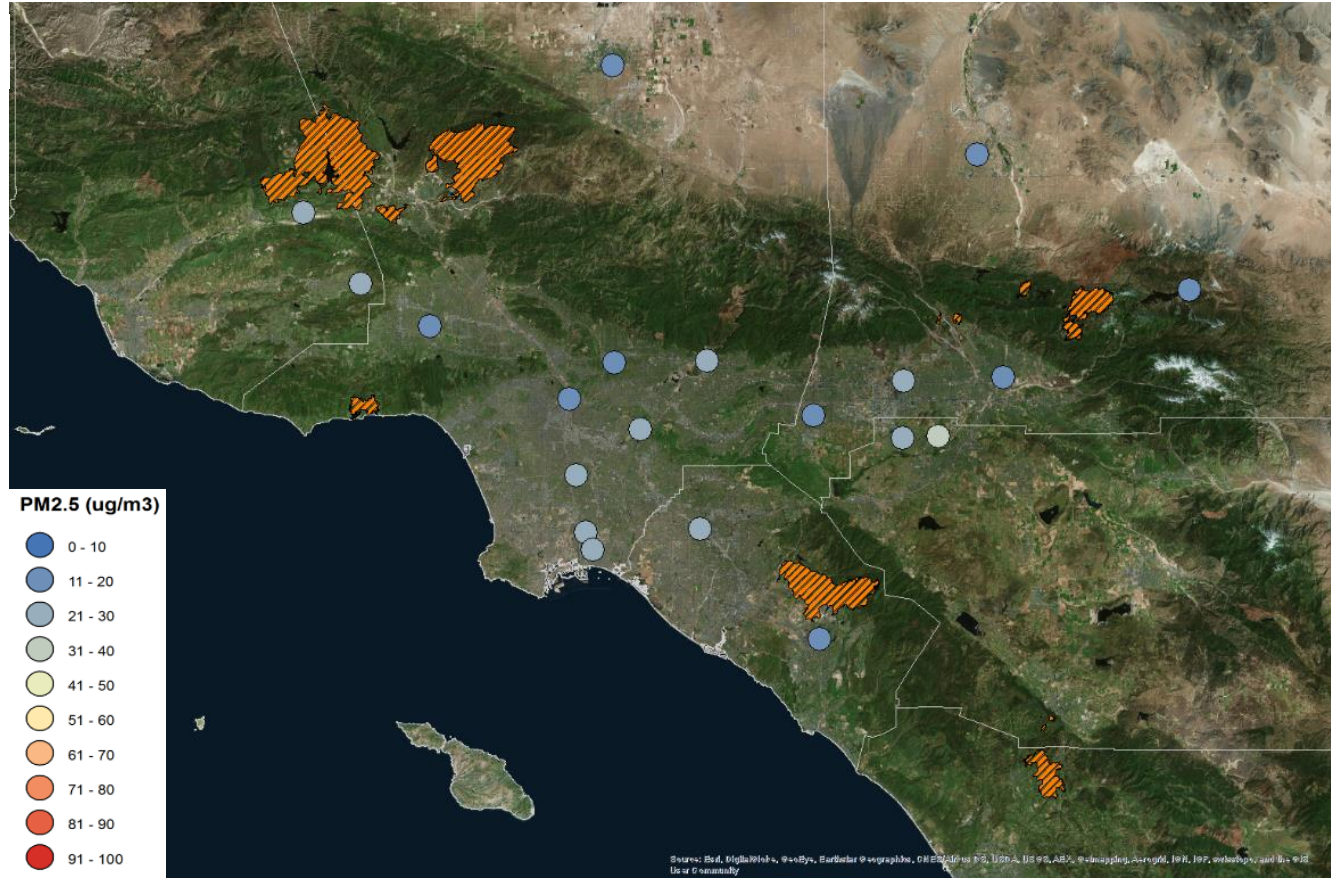

Fig. 32. Continued for (a) CALPUFF Adjustment Scheme and (b) Partial Plume Path Scheme. 


\section{Conclusion and Future Work}

Three years' worth of data was analyzed to find the association between daily asthma emergency department visits and exposure to $\mathrm{O}_{3}, \mathrm{NO}_{2}, \mathrm{CO}, \mathrm{PM}_{2.5}$, dew point temperature, air temperature, and winds during wildfire peaks. Two datasets per county were created to perform correlations. The first dataset included daily rates for all variables while the second dataset excluded all fire events that took place within that county. Among all the variables, the most significant correlation was that of asthma and $\mathrm{PM}_{2.5}$. This pair's correlation decreased considerably from the original dataset to the modified dataset during fall of 2007 given in Table 6. It is clear that fires contributed to the higher correlation between $\mathrm{PM}_{2.5}$ and asthma ED visits during this period. However, fires are not the sole reason for increases in asthma ED visits. Other factors like stress and emotion or respiratory infections could have contributed as well.

Furthermore, from Table 3 we know that the average number of asthma ED visits has increased over time. It is yet to be determined if this increase is due to fire events or other environmental or political influences. The data provided in this research may suggest designs in future studies on understanding the relationship between fires and health such as acres burned and asthma ED visits.

An outbreak of wildfires took place during the last 10 days of October 2007. Using this information, the wildfires were simulated using BlueSky's air modeling framework to assess the accuracy of $\mathrm{PM}_{2.5}$ concentrations produced by the WRF/CALMET/CALPUFF pathway. This pathway (Table 2), was uniquely chosen since it had not been used before to simulate wildfires in Southern California. 
A sensitivity analysis was conducted for the different terrain effect schemes.

Results from this model framework proved to be accurate within $10 \mu \mathrm{gm}^{-3}$ on October $24^{\text {th }}$ for all schemes, but varied for all other dates. From October $26^{\text {th }}$ and onward, $\mathrm{PM}_{2.5}$ underestimations were likely a result of the absence of modeled wildfires. A noteworthy amount of burned acres from wildfires in San Diego County were not included in the domain. Future work will include resizing the domain to include these fires, potentially providing an improved estimation of $\mathrm{PM}_{2.5}$ levels.

In addition, uncertainties in the pathway contributed to the variability of $\mathrm{PM}_{2.5}$ estimates. The ICS-209 summary relies heavily on information entered at the incident or dispatch level. Inadequacies include missing, incomplete, or incorrect records and untimely submission of final reports (Thompson et al. 2013). The information provided by this report is used for import into FEPS and thus needed for more accurate modeling, most importantly the daily perimeter growth of the fire. However, FEPS has its own limitations such as errors in characterizing fuels and fuel consumption (Hardy et al., 2001; Peterson, 1987; Peterson \& Sandberg, 1988). This surfaces from FEPS's usage of NFDRS which classifies fuel beds and fuel loads by region. Any variation in fuel loading can contribute up to $80 \%$ of the error associated with estimating emissions (Peterson, 1987; Peterson \& Sandberg, 1988).

The area source plume rise option in CALPUFF is designed to calculate the rise of buoyant plumes resulting from forest fires. However, complex terrain features influence meteorological conditions like temperature and wind patterns, creating a slight deviation in the location of the modeled plume and inexact concentration estimates. This 
is a direct result from WRF output that is regularly updated to provide more precise data that could help improve CALPUFF's modeling.

In conclusion, this study created a methodology that confirmed the association between asthma and increased levels of $\mathrm{PM}_{2.5}$ and explored a framework in BlueSky not previously used in the 2007 wildfires of Southern California. 


\section{References}

A User's Guide for the CALPUFF Dispersion Model. (n.d.). Retrieved April 21, 2016.

Abe, T., Y. Tokuda, S. Ohde, S. Ishimatsu, T. Nakamura, and R. B. Birrer, 2009: The relationship of short-term air pollution and weather to ED visits for asthma in Japan. The American Journal of Emergency Medicine, 27, 153-159.

Al-Hamdan, M. Z., W. L. Crosson, A. S. Limaye, D. L. Rickman, D. A. Quattrochi, M. G. Estes Jr, and A. S. Niskar, 2009: Methods for characterizing fine particulate matter using ground observations and remotely sensed data: potential use for environmental public health surveillance. Journal of the Air \& Waste Management Association, 59, 865-881.

American Lung Association ®. (n.d.). Retrieved February 26, 2014.

Anderson, G.K., D.V. Sandberg, and R. Norheim, 2004: Fire emission production simulator user's guide, version 1.0, report, Joint Fire Sci. Program, Boise, Idaho.

Barry, R.G., 2008: Mountain weather and climate. 3rd ed. Cambridge, United Kingdom: Cambridge University Press.

Billmire, M., N. H. French, T. Loboda, R. C. Owen, and M. Tyner, 2014: Santa Ana winds and predictors of wildfire progression in southern California. International Journal of Wildland Fire, 23, 1119-1129.

California Fire Siege 2007: An Overview. Sacramento, CA: California Dept. of Forestry and Fire Protection, 2008.

Carey, M. J., and I. Cordon, 1986: Asthma and climatic conditions: Experience from Bermuda, an isolated island community. Bmj, 293, 843-844.

Choi, Yu-Jin, and H.J.S. Fernando, 2007: Simulation of Smoke Plumes from Agricultural Burns: Application to the San Luis/Rio Colorado Airshed along the U.S./Mexico Border. Science of The Total Environment 388, 270-89.

Cibola National Forest and National Grasslands - Resource Management. (n.d.). Retrieved July 22, 2016.

Clements, C. B., 2011: Effects of Complex Terrain on Extreme Fire Behavior. Synthesis of Knowledge of Extreme Fire Behavior: Volume I for Fire Managers, 5. 
Cody, R. P., C. P. Weisel, G. Birnbaum, and P. J. Lioy, 1992: The effect of ozone associated with summertime photochemical smog on the frequency of asthma visits to hospital emergency departments. Environmental Research, 58, 184-194.

Deeming, J.E., R.E. Burgan, and J.D. Cohen, 1977: The National Fire Danger Rating System, 1978. Ogden, Utah: Intermountain Forest and Range Experiment Station, Forest Service, U.S. Dept. Of Agriculture.

Delfino, R. J., S. Brummel, J. Wu, H. Stern, B. Ostro, M. Lipsett, A. Winer, D. H. Street, L. Zhang, T. Tjoa, and D. L. Gillen, 2009: "The Relationship of Respiratory and Cardiovascular Hospital Admissions to the Southern California Wildfires of 2003." Occupational and Environmental Medicine, 66.3, 189-97.

Dudhia, J., 1989. "Numerical study of convection observed during winter monsoon experiment using a mesoscale two-dimensional model." J. Atmos. Sci., 46, 30773107

Durran, D.R., 1990: Mountain waves and downslope winds. Atmospheric Processes over Complex Terrain. B. Blumen Ed., American Meteorological Society, Boston, 5981.

Fire and Environmental Research Applications Team, 2006: Fire emission production simulator web page.

FRAP, 2012: Fire and Resource Assessment Program, California Department of Forestry and Fire Protection. Fire perimeters: Fire11_1.gdb. Retrieved November 13, 2012.

Girsh, L. S., E. Shubin, C. Dick, and F.A. Schulaner, 1967: A study on the epidemiology of asthma in children in Philadelphia. Journal of Allergy, 39, 347-357.

Goldstein, I. F., 1980: Weather patterns and asthma epidemics in New York City and New Orleans, U.S.A. International Journal of Biometeorology, 24, 329-339.

Holstius, D. M., C. E. Reid, B. M. Jesdale, and R. Morello-Frosch, 2012: Birth Weight following Pregnancy during the 2003 Southern California Wildfires. Environmental Health Perspectives, 120, 1340-1345.

Horel, J., M. Splitt, L. Dunn, J. Pechmann, B. White, C. Ciliberti, and J. Burks, 2002: Mesowest: Cooperative mesonets in the western United States. Bulletin of the American Meteorological Society, 83, 211-225. 
Houyoux, M.R., J. Vukovich, and J. Brandmeyer, 2000: Sparse Matrix Operator Kernel Emissions Modeling System (SMOKE) user manual, report, MCNC-North Carolina Supercomput. Cent., Environ. Programs, Research Triangle Park, N.C.

Hughes, M., A. Hall, 2009: Local and synoptic mechanisms causing southern California's Santa Ana winds. Climate Dynamics, 34, 847-857.

Jackson, B., D. Chau, K. Gurer, and A. Kaduwela, 2006: Comparison of ozone simulations using MM5 and CALMET/MM5 hybrid meteorological fields for the July/August 2000 CCOS episode. Atmospheric Environment, 40, 2812-2822.

Kumagai Y., M. Carroll, P. Cohn, 2004: Coping with interface wildfire as a human event: lessons from the disaster/hazards literature. J Forestry, 102, 28-32.

Künzli, N., E. Avol, J. Wu, W.J. Gauderman, E. Rappaport, J. Millstein, J.M. Peters, 2006: Health Effects of the 2003 Southern California Wildfires on Children. Journal of Respiratory and Critical Care Medicine, 174, 1221-1228.

Larkin, N., S.M. O'neill, R. Solomon, S. Raffuse, T. Strand, D.C. Sullivan, C. Krull, M. Rorig, J. Peterson, and S.A. Ferguson, 2009: The BlueSky Smoke Modeling Framework. International Journal of Wildland Fire Int. J. Wildland Fire, 18.8, 906.

Li, N., C. Sioutas, A. Cho, D. Schmitz, C. Misra, J. Sempf, and A. Nel, 2003: Ultrafine particulate pollutants induce oxidative stress and mitochondrial damage.

Environmental health perspectives, 111, 455.

Lu, R., and R.P. Turco, 1996: Ozone Distributions over the Los Angeles Basin: Threedimensional Simulations with the Smog Model. Atmospheric Environment, 30, 4155-4176.

Mireku, N., Y. Wang, J. Ager, R.C. Reddy, and A.P. Baptist, 2009: Changes in weather and the effects on pediatric asthma exacerbations. Annals of Allergy, Asthma \& Immunology, 103, 220-224.

Mlawer, E. J., S.J. Taubman, P.D. Brown, M.J. Iacono, and S.A. Clough, 1997: Radiative transfer for inhomogeneous atmosphere: RRTM, a validated correlated-k model for the longwave. J. Geophys. Res., 102, 663-682

Naeher, L. P., M. Brauer, M. Lipsett, J.T. Zelikoff, C.D. Simpson, J.Q. Koenig, and K.R. Smith, 2007: Woodsmoke Health Effects: A Review. Inhalation Toxicology, 19, 67-106. 
Nastos, P. T., A.G. Paliatsos, M. Papadopoulos, C. Bakoula, and K.N. Priftis, 2008: The Effect of Weather Variability on Pediatric Asthma Admissions in Athens, Greece. Journal of Asthma, 45, 59-65.

Nemmar, A., P.M. Hoet, B. Vanquickenborne, D. Dinsdale, M. Thomeer, M.F. Hoylaerts, and B. Nemery, 2002: Passage of inhaled particles into the blood circulation in humans. Circulation, 105, 411-414.

Peden, D. B., 2005: The epidemiology and genetics of asthma risk associated with air pollution. Journal of Allergy and Clinical Immunology, 115, 213-219.

Penttinen, P., K.L. Timonen, P. Tiittanen, A. Mirme, J. Ruuskanen, And J. Pekkanen, 2001: Number concentration and size of particles in urban air: effects on spirometric lung function in adult asthmatic subjects. Environmental health perspectives, 109, 319.

Phuleria, H., P.M. Fine, and Y. Zhu, 2005: Air Quality Impacts of the October 2003 Southern California Wildfires. J. Geophys. Res. Journal of Geophysical Research, 110, doi:10.1029/2004JD004626

Pouliot, G., T. Pierce, W. Benjey, S.M. O’Neill, S.A. Ferguson, 2005: Wildfire emission modeling: integrating BlueSky and SMOKE. Proceedings of the 14th Annual Emissions Inventory Conference, Atlanta, GA.

Raffuse, S. M., D.A. Pryden, D.C. Sullivan, N.K. Larkin, T. Strand, and R. Solomon, 2009: SMARTFIRE algorithm description. US Environmental Protection Agency, Research Triangle Park, NC, by Sonoma Technology, Inc., Petaluma, CA, and the US Forest Service, AirFire Team, Pacific Northwest Research Laboratory, Seattle, WA.

Ritz, T., A. Steptoe, C. Bobb, A.H. Harris, and M. Edwards, 2006: The Asthma Trigger Inventory: Validation of a Questionnaire for Perceived Triggers of Asthma. Psychosomatic Medicine, 68, 956-965.

Rossi, O. V., V.L. Kinnula, J. Tienari, and E. Huhti, 1993: Association of severe asthma attacks with weather, pollen, and air pollutants. Thorax, 48, 244-248.

Sanberg, D.V., G.K. Anderson, and R.A. Norheim, 2004: Fire emission production simulator [software] ver. 1.1.

Scire, J. S., D.G. Strimaitis, and R.J. Yamartino, 2000: A user's guide for the CALPUFF dispersion model. Earth Tech, Inc. Concord, MA. 
Scire, J. S., F.R. Robe, M.E. Fernau, and R.J. Yamartino, 2000b: A user's guide for the CALMET Meteorological Model. Earth Tech, USA, 37.

Skamarock W.C., J.B. Klem, J. Dudhia, D.O. Gill, D.M. Barker, W. Wang, and J.G. Powers, 2005: A description of the advanced research WRF Version 2. National Center for Atmospheric Research Technical Note NCAR/TN-468+STR. Boulder, $\mathrm{CO}$.

State of California, Department of Finance, E-4 Population Estimates for Cities, Counties, and the State, 2001-2010, with 2000 \& 2010 Census Counts. Sacramento, CA.

Strand, T. M., N. Larkin, K.J. Craig, S. Raffuse, D. Sullivan, R. Solomon, and D. Pryden, 2012: Analyses of BlueSky Gateway PM2. 5 predictions during the 2007 southern and 2008 northern California fires. Journal of Geophysical Research: Atmospheres, 117.

Sullivan, D. C., S.M. Raffuse, D.A. Pryden, K.J. Craig, S.B. Reid, N.J. Wheeler, T. Strand, 2008: Development and applications of systems for modeling emissions and smoke from fires: The BlueSky smoke modeling framework and SMARTFIRE. 17th International Emissions Inventory Conference, Portland, OR.

The NCAR Command Language (Version 6.3.0) [Software]. 2016:

UCAR/NCAR/CISL/TDD, Boulder, CO.

Thompson, M. P., 2013: Modeling Wildfire Incident Complexity Dynamics. PLoS ONE, 8.

Utell, M. J., and M.W. Frampton, 2000: Acute health effects of ambient air pollution: the ultrafine particle hypothesis. Journal of aerosol medicine, 13, 355-359.

Wegesser, T. C., K.E. Pinkerton, and J.A. Last, 2009: California Wildfires of 2008: Coarse and Fine Particulate Matter Toxicity. Environmental Health Perspectives, 117, 893-897.

"National Centers for Environmental Information (NCEI)". National Centers for Environmental Information. (n.d.).

White, M.C., R.A. Etzel, W.D. Wilcox, and C. Lloyd, 1994: Exacerbations of Childhood Asthma and Ozone Pollution in Atlanta, Environmental Research, 65, 56-68. 
Whiteman, C.D., 2000: Mountain Meteorology: Fundamentals and Applications. Oxford. New York. University Press. New York, 355pp.

Wiedinmyer, C., B. Quayle, C. Geron, A. Belote, D. Mckenzie, X. Zhang, S. O'Neill, and K.K. Wynne, 2006: Estimating Emissions from Fires in North America for Air Quality Modeling. Atmospheric Environment 40.19, 3419-432. 


\section{APPENDIX A.}

\section{Models and Acronyms}

\begin{tabular}{|c|c|}
\hline Acronym or model & Description \\
\hline AQS & Air Quality System \\
\hline AQMIS & Air Quality and Meteorological Information System \\
\hline $\mathrm{ARB}$ & California Air Resources Board \\
\hline BlueSky & BlueSky smoke modeling framework \\
\hline CALFIRE & California Department of Forestry and Fire Protection \\
\hline CALMET & Diagnostic 3-D meteorological processor for CALPUFF \\
\hline CALPUFF & Gaussian puff dispersion model \\
\hline $\mathrm{CDC}$ & Centers for Disease Control \\
\hline $\mathrm{CH} 4$ & Methane \\
\hline $\mathrm{CO}$ & Carbon Monoxide \\
\hline DISC & NASA Data and Information Services Center \\
\hline ED & Emergency Department \\
\hline EPA & US Environmental Protection Agency \\
\hline FEMA & Federal Emergency Management Agency \\
\hline FEPS & Fire Emissions Production Simulator \\
\hline GACC & Geographic Area Coordination Center \\
\hline GES & NASA Goddard Earth Sciences \\
\hline GIS & Geographic Information System \\
\hline ICD & International Classification of Diseases \\
\hline ICS-209 & Incident Command System 209 reports \\
\hline MM5 & Mesoscale Meteorological model Version 5 \\
\hline MODIS & Moderate Resolution Imaging Spectroradiometer \\
\hline NAAQS & National Ambient Air Quality Standards \\
\hline NAM & North American Mesoscale Forecasting System \\
\hline
\end{tabular}




\begin{tabular}{ll}
\hline NASA & US National Aeronautics and Space Administration \\
\hline NCEI & National Centers for Environmental Information \\
\hline NCEP & National Centers for Environmental Predictions \\
\hline NFDRS & US National Fire Danger Rating System \\
\hline NOAA & US National Oceanic and Atmospheric Administration \\
\hline OSHPD & Nitrogen Dioxide \\
\hline PM & Office of Statewide Health Planning and Development \\
\hline PPM & Particulate Matter \\
\hline RMA & Parts per million \\
\hline RRTM & Riverside Municipal Airport \\
\hline SCAQMD & Rapid Radiative Transfer Model \\
\hline SLAMS & South Coast Air Quality Management District \\
\hline SMARTFIRE & State or Local Air Monitoring Stations \\
\hline SMOKE & Satellite Mapping Automated Reanalysis Tool for Fire \\
\hline Incident Reconciliation
\end{tabular}

